

\section{DISCLAIMER}

This report was prepared as an account of work sponsored by an agency of the United States Government. Neither the United States Government nor any agency Thereof, nor any of their employees, makes any warranty, express or implied, or assumes any legal liability or responsibility for the accuracy, completeness, or usefulness of any information, apparatus, product, or process disclosed, or represents that its use would not infringe privately owned rights. Reference herein to any specific commercial product, process, or service by trade name, trademark, manufacturer, or otherwise does not necessarily constitute or imply its endorsement, recommendation, or favoring by the United States Government or any agency thereof. The views and opinions of authors expressed herein do not necessarily state or reflect those of the United States Government or any agency thereof. 


\section{DISCLAIMER}

Portions of this document may be illegible in electronic image products. Images are produced from the best available original document. 
The facilities of Argonne National Laboratory are owned by the United States Government. Under the terms of a contract (W-31-109-Eng-38) between the U.S. Department of Energy, Argonne Universities Association and The University of Chicago, the University employs the staff and operates the Laboratory in accordance with policies and programs formulated, approved and reviewed by the Association.

\section{MEMBERS OF ARGONNE UNIVERSITIES ASSOCIATION}

The University of Arizona Carnegie-Mellon University Case Western Reserve University The University of Chicago University of Cincinnati Illinois Institute of Technology University of Illinois Indiana University lowa State University The University of lowa
Kansas State University The University of Kansas Loyola University Marquette University Michigan State University The University of Michigan University of Minnesota University of Missouri Northwestern University University of Notre Dame
The Ohio State University Ohio University

The Pennsylvania State University Purdue University

Saint Louis University Southern Illinois University The University of Texas at Austin Washington University Wayne State University The University of Wisconsin

\section{NOTICE}

This report was prepared as an account of work sponsored by the United States Government. Neither the United States nor the United States Department of Energy, nor any of their employees, nor any of their contractors, subcontractors, or their employees, makes any warranty, express or implied, or assumes any legal liability or responsibility for the accuracy, completeness or usefulness of any information, apparatus, product or process disclosed, or represents that its use would not infringe privately-owned rights. Mention of commercial products, their manufacturers, or their suppliers in this publication does not imply or connote approval or disapproval of the product by Argonne National Laboratory or the U. S. Department of Energy. 
ARGONNE NATIONAL LABORATORY

9700 South Cass Avenue

Argonne, Illinois 60439

\section{ANALYSIS OF COSTS AND SCARCE FUEL SAVINGS ASSOCIATED WITH NINE EASTERN AND NORTH CENTRAL CENTER CITY CONVERSIONS TO A DISTRICT ENERGY SYSTEM}

by

A.A. Davis, D.J. Santini, S.M. Marder*, and S.S. Bernow**

Energy and Environmental Systems Division

February 1979

This report was prepared as an account of work sponsored by the United States Government. Neither the

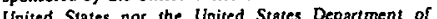
Energ. Energ. hor any or their employes, nor any of their

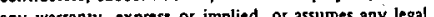
any wartanty, express or implied, or assomes any legal

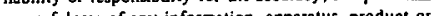
or use fulness of any information, apparalss, produer or process disclosed, or represents that its use would no infringe privately owned rights.

Work Sponsored by

U.S. DEPARTMENT OF ENERGY

Assistant Secretary for Conocrvation and Solar Applications Buildings and Community Systems Division, Community Systems Branch

*ESCOR, Evanston, I11., ANI. Connsult ant

**Energy Systems Research Group; Inc. (ESRG), Boston, Mass.; ANL Consullant 
THIS PAGE

\section{WAS INTENTIONALLY LEFT BLANK}


FOREWORD $\ldots \ldots \ldots \ldots \ldots \ldots \ldots \ldots \ldots \ldots \ldots \ldots \ldots \ldots \ldots \ldots \ldots \ldots \ldots \ldots \ldots \ldots \ldots \ldots \ldots$

ABSTRACT $\ldots \ldots \ldots \ldots \ldots \ldots \ldots \ldots \ldots \ldots \ldots \ldots \ldots \ldots \ldots \ldots \ldots \ldots \ldots \ldots \ldots \ldots$

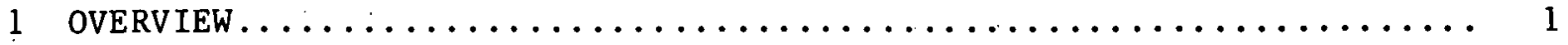

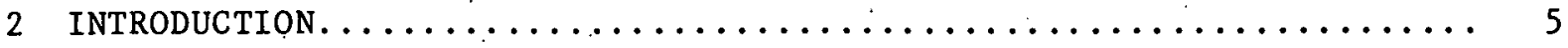

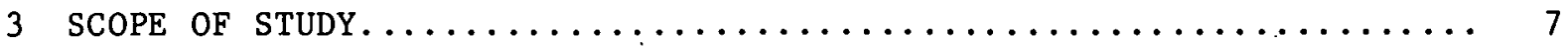

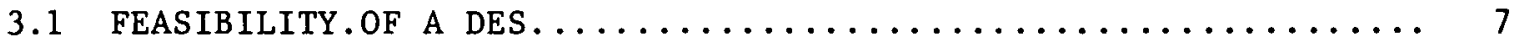

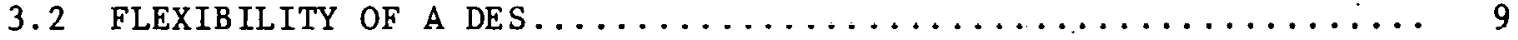

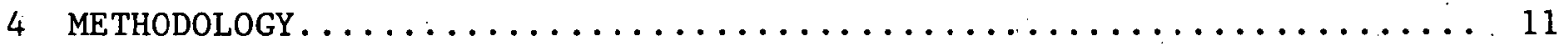

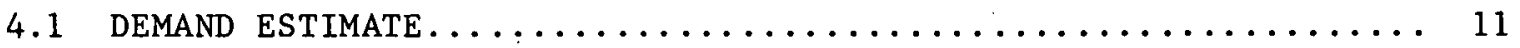

4.1.1 ANL/ESCOR Heating/Cooling Demand Determination........ 11

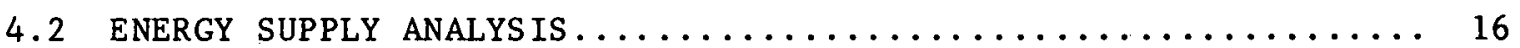

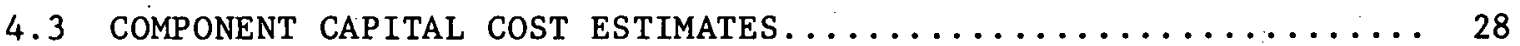

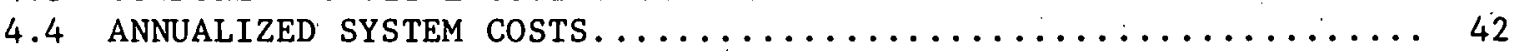

5 COMPARISON WITH ALTERNATE ENERGY DELIVERY OPTIONS............ 47

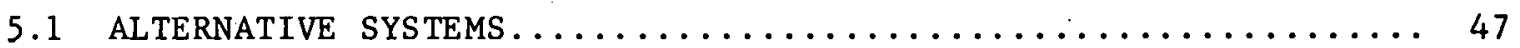

5.1 .1 Coal-to-Electricity to Heat................. 49

5.1 .2 Coal-to-Gas via Gasification to Heat.............. 50

5.1 .3 Coal-to-0il via Liquefaction to Heat............. 51

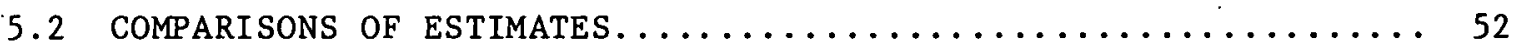

6 ESTIMATES OF SCARCE-FUEL SAVINGS $\ldots \ldots \ldots \ldots \ldots \ldots \ldots \ldots \ldots \ldots \ldots \ldots \ldots \ldots \ldots$

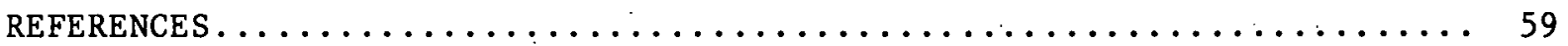




\section{LIST OF TABLES}

Table

No.

Title

Page

1.1 Cost per Million Btus - Alternate Options $\left(\$ / 10^{6}\right.$. Btu) ....... 2

1.2. Annual City Specific Fuel Consumption and Scarce Fuel Savings

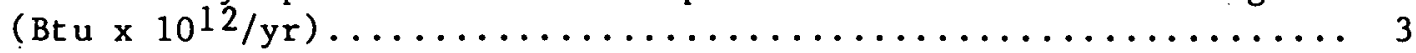

3.1 Basic Heat Data on Cities under Study $\ldots \ldots \ldots \ldots \ldots \ldots \ldots \ldots$

4.1 City Building Square Footage (sq ft $\left.\times 10^{3}\right) \ldots \ldots \ldots \ldots \ldots \ldots$

1.2 Encrgy Demand Factoro $\left(B t u / f t^{2}\right) \ldots \ldots \ldots \ldots \ldots \ldots \ldots \ldots \ldots$

4.3 Results of Existing Retrofit Options................. 27

4.4 Capital Costs City/Zone $\left(\$ \times 10^{6}\right) \ldots \ldots \ldots \ldots \ldots \ldots \ldots \ldots \ldots \ldots \ldots \ldots \ldots \ldots \ldots$

4.5 DES -- Operation and Maintenance Costs $\left(\$ \times 10^{6} / \mathrm{yr}\right) \ldots \ldots \ldots 4$

4.6 Cost per $10^{6}$ Btu at 20 Yr Equipment Lifetimes. and $8 \%$ of $20 \%$

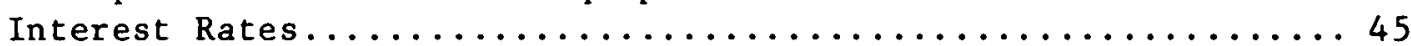

5.1 Costs of Coal-Electric Options (Total City) -- ( $\$ \times 10^{6}$ and

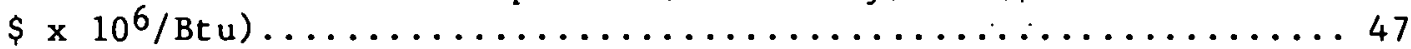

5.2 Costs of Coal Gasification Option (Total City) -- ( $\$ \times 10^{6}$

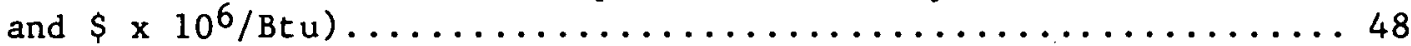

5.3 Costs -- Coal-Liquids Option (Total City) -- ( $\$ \cdot \mathbf{x} 10^{6}$ and

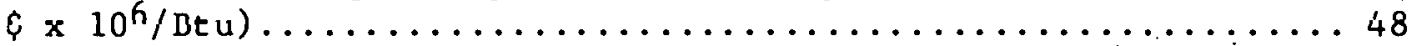

6.1 Heating/Cooling Fuel Use Percentages for Residential

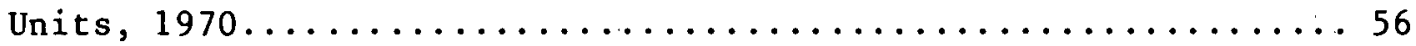

6.2 Estimates of Heating/Cooling Fuel Use Percentages for Downtowi Commercial/Institutional Buildings............. 56 


\section{LIST OF FIGURES}

Figure

No.

$\underline{\text { Title }}$

$\underline{\text { Page }}$

4.1 Average Day Heat Demand Profile -- Washington, D.C. (ANL/

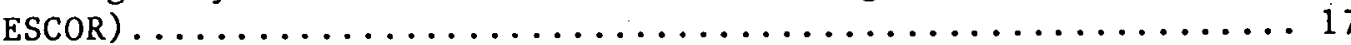

4.2 Average Day Heat Demand Profile for Washington, D.C. (BNL/

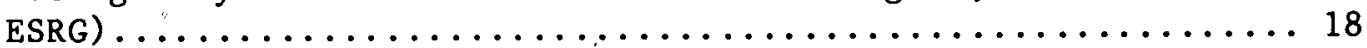

4.3. Average Day Heat Demand Profile -- st. Louis............. 19

4.4 Average Day Heat Demand Profile -- Cleveland............. 20

4.5 Average Day Heat Demand Profile -- Milwaukee........... 21

4.6 Average Day Heat Demand Profile -- Detroit............. 22

4.7 Average Day Heat Demand Profile -- Chicago.............. 23

4.8 Average Day Heat Demand Profile -- Boston.............. 24

4.9 Average Day Heat Demand Profile -- Baltimore............ 25

4.10 Average Day Heat Demand Profile -- Philadelphia........... 26

4.11 Washington,. D.C. -- Demand Zones \& Supply Lines (ANL/

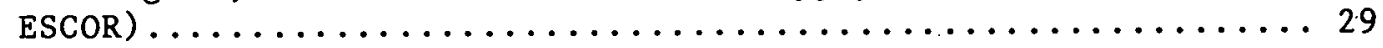

4.12 Washington, D.C. -- Demand Zones \& Supply Lines (BNL/

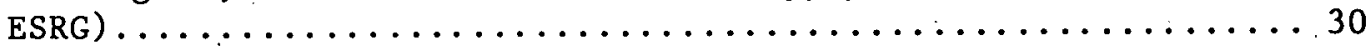

4.13 St. Louis -- Demand Zones and Supply Lines............ 31

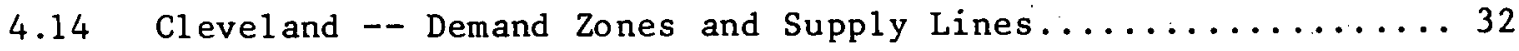

4.15 Milwaukee - Demand Zones and Supply Lines............. 33

4.16 Detroit -- Demand Zones and Supply Lines.............. 34

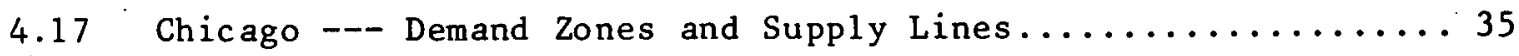

4.18 Boston -- Demand Zones and Supply Lines.............. 36

4.19 Baltimore -- Demand Zones and Supply Lines............ 37

4.20 Philadelphia -- Demand Zones and Supply Lines............ 38 


\section{THIS PAGE}

\section{WAS INTENTIONALLY LEFT BLANK}


FOREWORD

This assessment of a cogeneration technology devoted to heating of residential and commercial buildings by means of retrofit of exisiting electric power plants is one of several analyses of integrated community energy systems conducted by the Energy and Environmental Systems Division of Argonne National Laboratory. The work reported here was conducted under sponsorship of the Energy Research and Development Administration and the Department of Energy. Sponsorship is now from the Division of Buildings and Community Systems under the Office of the Assistant Secretary for Conservation and Solar Application at the Department of Energy (DOE).

The objective of this study was to develop rough estimates of the direct economic viability of the system as well as its potential for total and scarce-fuel energy savings. The results of the study indicate that in major northern U.S. cities, cogeneration for heating is more economical than electricity for heating only and may prove to be as viable a source of heat energy as coal gasification or liquefaction in the event that gas and oil suppliers become appreciably scarcer than they are today.

This is the final report in a series prepared by four different research groups. Two semi-independent research efforts for the North-Central U.S. Region and the Northeast U.S. Region have been conducted. This report eliminates the major differences between the two research efforts and presents the results as a unified work. Although Brookhaven National Laboratory, the Energy Systems Research Group, and ESCOR all contributed significantly to this effort, the final analyses and descriptions were the responsibility of the Argonne National Laboratory authors.

Among authors, Alan Davis specified the engineering attributes arising from the retrofit of power plants; Danizo Santini developed the demand estimation methodology used by the Argonne National Laboratory/ESCOR study group and defined the cost evaluation methodology. Sid Marder acted as a valuable critic of the methodology and executed cost estimates for the North Central cities. He is also the primary author of this text. Steve Bernow made a critical contribution to the characterization of the transmission/distribution system, developed a separate demand estimation methodology, and revised the Brookhaven National Laboratory/Energy Systems Research Group work on Northeastern cities to more closely match the Argonne/ESCOR cost estimates.

Although numerous deficiencies exist in this research, the authors are confident that the interpretation and conclusions drawn are justifiable on the basis of the quality of work presented. 


\section{THIS PAGE \\ WAS INTENTIONALLY \\ LEFT BLANK}




\title{
COSTS OF URBAN AREA RETROFIT TO DISTRICT HEATING SYSTEMS: NORTHEAST AND NORTH-CENTRAL CITIES
}

\begin{abstract}
This study considers the major urbanized areas of nine U.S. cities to arrive at rough estimates of costs required to retrofit them with district energy systems (DES). Only those costs associated with heating and hot water are addressed here.* Demand estimates and energy supply analyses are made, and component capital costs are estimated to arrive at annualized system costs. Finally, a comparison of alternative energy delivery options is made, and estimates of scarce-fuel savings are derived.
\end{abstract}

\section{OVERVIEW}

This study was made to estimate reasonably accurately the costs required to retrofit major portions of nine U.S. cities with district energy systems (DES). Detailed analyses to date have considered district heating; this report summarizes two independent efforts and constitutes a summary of work undertaken by Argonne National Laboratory (ANL/ESCOR) for five midwestern cities and Washington, D.C., l as well as work undertaken by the Energy Systems Research Group (ESGR) and Brookhaven National Laboratory (BNL) of three eastern cities plus Washington, D.C.2,3 Methodologies of the two studies were reconciled for consistency, and the closeness of results of these two semi-independent studies lends credence to the findings. It should be carefully noted that this study covers costs of retrofit only to a heating and hot water mode. Selective inclusion of cooling can reduce the overall cost. Such costs will be the subject of future work. The systems under cosideration here would primarily involve retrofitting existing electric generating facilities to cogenerate both electric and thermal energy. Secondarily, they would involve existing district heating systems, and, in tertiary cases, new supplemental boilers would be installed. Costs for district heating systems in each city were compared against coal-electric, coal-gasification, and coal-liquefaction options. The results, summarized in Table 1.1, indicate that retrofitting of major metropolitan areas to a cogeneration-based district heating mode is within the range of economic feasibility. Furthermore, as costs of energy rise, and as the availability of gas and oil decreases, the viability of such a district heating and cooling system increases. This report also estimates potential savings in scarce fuels (oil and gas) created by switching from existing space heat fuel mixes to a cogeneration mnde. Results of such estimates are summarized in Table 1.2 .

Based on these results, this report generally concludes that President Carter's call for investigation and analysis of a resurgence of cogeneration

* Subsequent research has shown that cooling may be selectively included, especially in central business districts, and that the costs per unit of energy delivered $c$ an thereby be reduced. 
Table 1.1. Cost per Million Btus -- Alternative Options $\left(\$ / 10^{6} \mathrm{Btu}\right)^{(\mathrm{a})}$

\begin{tabular}{|c|c|c|c|c|c|c|c|c|}
\hline City & E & $\begin{array}{c}\text { DES } \\
\text { High } \\
\text { Estimate }\end{array}$ & $\begin{array}{c}\text { DES } \\
\text { Low } \\
\text { Estimate }\end{array}$ & $\begin{array}{c}\text { Coal } \\
\text { to } \\
\text { Electri- } \\
\text { city }\end{array}$ & $\begin{array}{l}\text { Coal } \\
\text { to Gas } \\
\text { to Hear }\end{array}$ & $\begin{array}{l}\text { Coal to } \\
\text { Liquid } \\
\text { to Heat }\end{array}$ & $\begin{array}{l}1977 \text { Gas } \\
\text { Residential }\end{array}$ & $\begin{array}{l}\text { Price } \\
\text { Estimate(b) } \\
\text { Commercial }\end{array}$ \\
\hline $\begin{array}{l}\text { Wasington } \\
\text { (ANL/ESCOR) }\end{array}$ & $\begin{aligned} & 8 \%-20 \mathrm{yr}^{(c)} \\
& 20 \%-20 \text { yr }\end{aligned}$ & $\begin{array}{l}11.52 \\
19.46\end{array}$ & $\begin{array}{l}5.15 \\
8.73\end{array}$ & $\begin{array}{l}19.96 \\
36.36\end{array}$ & $\begin{array}{l}6.26 \\
8.69\end{array}$ & $\begin{array}{l}6.51 \\
9.26\end{array}$ & . & \\
\hline $\begin{array}{l}\text { Washington } \\
\text { (BNL/ESRG) }\end{array}$ & $\begin{array}{r}8 \%-20 \text { yr } \\
20 \%-20 \text { yr }\end{array}$ & $\begin{array}{l}10.85 \\
18.48\end{array}$ & $\begin{array}{l}4.89 \\
8.51\end{array}$ & $\begin{array}{l}17.75 \\
32.19\end{array}$ & $\begin{array}{l}6.26 \\
8.69\end{array}$ & $\begin{array}{l}6.51 \\
9.26\end{array}$ & 4.77 & $3: 97$ \\
\hline St Louis & $\begin{array}{r}8 \%-20 \text { yr } \\
20 \%-20 \text { yr }\end{array}$ & $\begin{array}{l}12.95 \\
21.93\end{array}$ & $\begin{array}{l}5.61 \\
9.53\end{array}$ & $\begin{array}{l}20.14 \\
36.97\end{array}$ & $\begin{array}{l}5.67 \\
8.10\end{array}$ & $\begin{array}{l}6.03 \\
8.78\end{array}$ & 3.02 & 2.51 \\
\hline Clevel and & $\begin{array}{r}8 \%-20 \text { yr } \\
20 \%-20 \text { yr }\end{array}$ & $\begin{array}{l}11.59 \\
19.71\end{array}$ & $\begin{array}{l}4.82 \\
8.34\end{array}$ & $\begin{array}{l}16.46 \\
30.00\end{array}$ & $\begin{array}{l}5.67 \\
8.10\end{array}$ & $\begin{array}{l}6.03 \\
8.78\end{array}$ & 3.25 & 2.97 \\
\hline Mi lwaukee & $\begin{array}{r}8 \%-20 \text { yr } \\
20 \%-20 \text { yr }\end{array}$ & $\begin{array}{l}10.95 \\
18.43\end{array}$ & $\begin{array}{l}4.66 \\
7.93\end{array}$ & $\begin{array}{l}16.05 \\
29.23\end{array}$ & $\begin{array}{l}5.67 \\
8.10\end{array}$ & $\begin{array}{l}6.03 \\
8.78\end{array}$ & 3.79 & 3.20 \\
\hline Detroit & $\begin{array}{r}8 \%-20 \text { yr } \\
20 \%-20 \text { yr }\end{array}$ & $\begin{array}{l}12.57 \\
20.95\end{array}$ & $\begin{array}{l}5.47 \\
9.20\end{array}$ & $\begin{array}{l}15.31 \\
27.84\end{array}$ & $\begin{array}{l}5.67 \\
8.10\end{array}$ & $\begin{array}{l}6: 03 \\
8: 78\end{array}$ & 3.42 & 3.28 \\
\hline Chicago & $\begin{array}{r}8 \%-20 \text { yr } \\
20 \%-20 \text { yr }\end{array}$ & $\begin{array}{l}10.14 \\
17.08\end{array}$ & $\begin{array}{l}4.66 \\
7.94\end{array}$ & $\begin{array}{l}20.22 \\
37.12\end{array}$ & $\begin{array}{l}5.67 \\
8.10\end{array}$ & $\begin{array}{l}6.03 \\
8.78\end{array}$ & $3 . \pm 1$ & 2.82 \\
\hline Boston & $\begin{array}{r}8 \%-20 \text { yr } \\
20 \%-20 \text { yr }\end{array}$ & $\begin{array}{l}12.24 \\
20.57\end{array}$ & $\begin{array}{l}5.83 \\
9.91\end{array}$ & $\begin{array}{l}16.35 \\
29.87\end{array}$ & $\begin{array}{l}6.26 \\
8.69\end{array}$ & $\begin{array}{l}6.51 \\
9.26\end{array}$ & 3.59 & 3.66 \\
\hline Baltimore & $\begin{array}{r}8 \%-20 \text { yr } \\
20 \%-20 \text { yr }\end{array}$ & $\begin{array}{l}12.55 \\
21.11\end{array}$ & $\begin{array}{l}5.58 \\
9.59\end{array}$ & $\begin{array}{l}16.90 \\
29.63\end{array}$ & $\begin{array}{l}6.26 \\
8.69\end{array}$ & $\begin{array}{l}6.51 \\
9.26\end{array}$ & 6.66 & 5.74 \\
\hline Philadelphia & $\begin{array}{r}8 \%-20 \mathrm{yr} \\
20 \%-20 \mathrm{yr}\end{array}$ & $\begin{array}{l}11.43 \\
19.14\end{array}$ & $\begin{array}{l}5.18 \\
8.83\end{array}$ & $\begin{array}{l}15.98 \\
28.83\end{array}$ & $\begin{array}{l}6.26 \\
8.69\end{array}$ & $\begin{array}{l}6.51 \\
9.26\end{array}$ & 4.66 & 4.06 \\
\hline
\end{tabular}

(a) These represent costs per final Btu of heating services delivered in the building. All conversion steps are included.

(b) Eased on state averages for 1976 escalated $22 \%$ and using $67 \%$ efficient gas furnace. Note that these are average costs and do not fully represent the cost of new gas. Thus marginal cost pricing would increase these values substantially and show cogeneration's true position.

(c) Costs are annualized in two ways:

$8 \%-20$ yr is equivalent to an $8 \%$ interest rate over a 20 yr 1 ife.

$20 \%-20 \mathrm{yr}$ is equivalent to a $20 \%$ interest rate over a 20 yr 1 ife. 
Table 1.2. Fuel Consumption and Scarce Fuel Savings (Btu $\times 10^{12} / \mathrm{yr}$ )

\begin{tabular}{|c|c|c|c|c|c|c|c|c|c|c|c|c|}
\hline & \multicolumn{6}{|c|}{ Current Fuel Consumption } & \multirow{2}{*}{\multicolumn{3}{|c|}{$\begin{array}{l}\text { Fuel Consumption } \\
\text { Cogeneration }\end{array}$}} & \multirow{2}{*}{\multicolumn{2}{|c|}{ Btu Saving }} & \multirow{3}{*}{$\begin{array}{c}\text { Percent } \\
\text { Scarce } \\
\text { Fuel } \\
\text { Saved }\end{array}$} \\
\hline & \multirow[b]{2}{*}{ Gas } & \multirow[b]{2}{*}{ Oil 1} & \multirow[b]{2}{*}{$\begin{array}{l}\text { Oil } \\
\text { Electric }\end{array}$} & \multirow{2}{*}{$\begin{array}{l}\text { Coall } \\
\text { Nuclear } \\
\text { Electric }\end{array}$} & \multirow{2}{*}{$\begin{array}{l}\text { Coal } \\
\text { and } \\
\text { Other }\end{array}$} & \multirow[b]{2}{*}{ Total } & & & & & & \\
\hline & & & & & & & $\begin{array}{l}\text { Oill } \\
\text { Gas }\end{array}$ & $\begin{array}{l}\text { Coal/ } \\
\text { Nuclear }\end{array}$ & Total & Total & Oil/ & \\
\hline $\begin{array}{l}\text { Washingt on } \\
\text { (ANL/ESCOR) }\end{array}$ & 18.3 & 20.4 & 1.1 & 1.5 & 5.1 & 46.4 & 4.3 & 16.2 & 20.5 & 25.9 & 35.5 & 89 \\
\hline $\begin{array}{l}\text { Washingt on } \\
(\text { BNL/ESRG) }\end{array}$ & 29.3 & 23.0 & 0.4 & 1.8 & 2.6 & 57.1 & 7.5 & 12.5 & 20.0 & 37.1 & 45.2 & 86 \\
\hline St. Louis & 31.8 & 6.7 & 0.1 & 0.6 & 1.8 & 41.0 & 4.4 & 14.7 & 19.1 & 21.9 & 34.2 & 89 \\
\hline Cleveland & 54.4 & 6.5 & 0.1 & 1.0 & 3.4 & 65.4 & 6.1 & 22.9 & 29.0 & 36.4 & 54.9 & 90 \\
\hline Nilwaukee & 44.3 & 18.3 & 0.1 & 1.1 & 6.4 & 70.2 & 5.2 & 25.8 & 31.0 & 39.2 & 57.5 & 92 \\
\hline Letroit & 79.1 & 8.4 & 0.3 & 1.4 & 13.0 & 102.2 & 11.6 & 33.2 & 44.8 & 57.4 & 76.2 & 87 \\
\hline Chicago & 78.3 & 53.9 & 0.6 & 2.5 & 6.7 & 140.0 & 12.3 & 49.1 & 61.4 & 78.6 & 120.5 & 91 \\
\hline Eioston & 18.9 & 39.2 & 1.1 & 0.4 & 0.3 & 59.9 & 17.4 & 16.7 & 34.1 & 25.8 & 41.8 & 71 \\
\hline Baltimore & 36.1 & 37.4 & 0.4 & 1.4 & 1.0 & 76.3 & 14.2 & 16.4 & 30.6 & 45.7 & 59.7 & 81 \\
\hline Philadelphia & 80.9 & 50.6 & 1.0 & 1.7 & 4.3 & 138.5 & 16.9 & 46.4 & 63.3 & 75.2 & 115.6 & 87 \\
\hline
\end{tabular}

(a) Oil/gas savings can be greatar than total savings because of substitution of coal for oil and gas as primary fuels. 
and district heating was well founded. The additional work being done for Minneapolis-St. Paul ${ }^{4}$ should identify more closely the site-specific factors that will determine whether cost estimates will fall within the high or low estimates projected in this study.

Not covered here are the myriad of institutional problems that would occur should an option be chosen. These problems may have more impact than technical or economic consideraions. Additional economic considerations included here do not examine the indirect costs and benefits of the DES technology. For example, current research underway at ANL is expected to show social benefits of the DES technology because it should employ more minorities than its competitors. As another example, inconvenience to commerce and commuters could occur when streets are dismantled for installation of transmission lines. Some compensation would result if this work could be made to coincide with normal road repairs. However, further study is needed in this area. The reaction of state and local officials, as well as the attitude of the general public, are likely to be important determinants of DES feasibility.

An equally important factor is that success of the project would require relatively large areas of a city and large percentages of customers to be retrofitted in a short period of time. The option of installing a system and then soliciting users is impractical. Success depends on the availability of a firm user list long before actual construction starts. This implies that there must be a general acceptance by end users, or, alternatively, that government must require the use of such a system. It is most likely that long-term unavailability of fuel would be a gradual occurrence, rather than a sharp break. Therefore, use out of necessity will not arise at once for a large block of potential users.

To date, projected shortages of fuels have been met in various ways. Most common have been bans on new gas hookups. For example, in central Illinois, new building space owners have the option of electric heat or propane. This new need has been met. by gradual increases in electrical capacity. A gradual increase in capacity, rather than a large "block" increase, as would be the case in a DES, has mitigated some of the institutional problems. In fact, the potential for the alternatives to DES to be phased in slowly through existing (or incrementally expanded) transmission systems is the strongest argument for their use.

In summary, the DES option falls within economic bounds that make it a possible future option. Detailed technical analysis and past experience have made it clear that no overruling technical reasons exist to abandon the option. However, institutional and indirect socioeconomic problems need much more detailed study. Even the detailed study of a Minneapolis-St. Paul DES has not yet examined many of the issues explicitly. 4

This study will include a second volume, or appendix of calculations, to allow verification of the values presented here and to form the basis for new methodology studies. 


\section{INTRODUCTION}

A previous study has indicated that certain U.S. cities have a fuel savings potential that would warrant a closer look at the feasibility of DES retrofit. 5 From that study's list of potential cities, this report considers Washington, D.C., St. Louis, Cleveland, Milwaukee, Detroit, Chicago, Boston, Baltimore, and Philadelphia. Initially, Washington, D.C., was the subject of a joint study by the ANL/ESCOR study group, 6 and the BNL/ESRG study group.* These two semi-independent studies have yielded results which, within the scope of techniques used, are relatively close. Such results allow confident extrapolation of the methodology used in the earlier Washington, D.C., study to the other cities under consideration 1,2 In this report, the most significant differences in the two study groups' methods are resolved, and results are presented for all nine cities.

This study will show that DES, although fraught with institutional problems, can yield significant benefits -- certainly from a fuel conservation viewpoint, and in a more limited sense, from an economic viewpoint as well. The extent of such benefits is covered in more breadth here than in past efforts. Although this report is fairly detailed, it is nevertheless simply a first step toward potential retrofitting of a major city. In essence, it is merely a demand-and-supply analysis. Site-specific criteria are utilized in the analysis; however, the criteria are still at a level that would need specific refinement before a rational design $c$ an be made to proceed with $a$ retrofit operation.

The overall purpose here is to demonstrate that the concept of DES retrofit is competitive with other options. Two events could foster the serious considertion of a DES, and this report presupposes that either of these two events is possible, and, indeed, probable.

The first event possible is that the cost of heat supplied to : the type of space considered will accelerate at a rate faster than other items. Certainly this has been true since 1973 and undoubtedly will continue to be so. For example, the low-cost estimate for DES retrofit found in Cleveland was $\$ 4.82 / 10^{6} \mathrm{Btu}$ of final heat energy provided. In areas where the cost of new natural gas or fuel oil has reached that level, $* *$ the $\overline{D E S}$ option is potentially competitive from a purely economic viewpoint.

A comparison can be made with the average cost of home heating. fuels now in use. For example, the cost of residential heating oil in the Midwest in January, 1977 , was about $40.75 \not /$ per gal. At approximately $0.14 \times 10^{6}$ Btus/gal, the usable costs (assuming a $63 \%$ efficient furnace) 8 would be

* See title page.

**Such as liquified natural gas importation in Boston. Costs of LNG in Ref. 7 were at the $\$ 4.82 / 10^{6}$ Btu level in 1975. Dollar costs here have been updated to 1977 dollars. 
$\$ 4.62 / 10^{6} \mathrm{Btu}$. Natural gas, at an average price of $\$ 1.91 / 10^{6} \mathrm{Btu}$ in a $67 \%$ efficient furnace ${ }^{8}$ has an ultimate cost of $\$ 2.84 / 10^{6}$ Btu. This example demonstrates that a DES low-cost estimate of $\$ 4.79 / 10^{6}$ Btu is not as out of line as might have been assumed at first glance.

The second event that would enhance the practicability of DES retrofit involves the possibility that traditional (gaseous and liquid) fossil fuels will become unavailable (at any price) in the quantities needed by the cities. Should this occur, available options for fuel supply must be found. Although many alternatives are available, a DES certainly would be one of them. Under the circumstances, the most probable alternative for the U.S. would be to turn to its abundant coal supplies. Therefore, this report compares the DES options with:

(1) a coal-electric system;

(2) coal-gasification systems;

(3) coal-1iquefaction systems.

By its very nature, this DES option must be instituted in fairly large blocks; thus, to some extent, it precludes the phase-in approach allowed by other alternatives.

Decreasing gaseous and liquid fossil-fuel supplies in the aggregate will affect various end-users in different ways Society, as a whole, must determine which sector will suffer the effects of a shortfall and to what degree. It is logical to assume that those sectors that have the best mechanisms (both technically and economically) to adapt to new energy sources will be the first to be curtailed. Traditionally, large industry is curtailed first. Thus, it is expected that residential, then commercial users will be given priority for scarce fuels. Although this does not preclude the eventuality of scarce-fuel curtailments to urban cores, it will effectively delay the time at which an alternate energy supply becomes imperative to maintain white-collar employment in the central business districts of major urban areas.

In brief, economic viability alone will not determine the implementation of DES; rather, such a decision will be intimately entwined with a myriad of institutional problems. 


\section{SCOPE OF STUDY}

This study deals with the center cities of nine major northern U.S. urbanized areas. In all cases, except Chicago, the proposed DES systems would supply heating and hot-water requirements to most of the center city. Areas to be serviced by the proposed DES were determined by the total supply that could be made available from existing sources, and, in some cases, by minor additions of thermal boilers. Chicago presented a case, probably matched only by New York City, in which the demand was so great that available supplies could satisfy only a fraction of the required demand. This fact was further complicated because Commonwealth Edison Co. supplies power to the central city mainly from distant electric generating facilities.

Table 3.1 details the peak period power demand and supply availability factors for the nine cities under study. It also relates information on the percentage of the city proper that would. fall under the DES. The case of Chicago should be noted because here only the densest areas are covered. Because higher density of demand implies lower DES costs, the final economic projections then appear to make Chicago the least costly candidate for DES. However, the supply network costs have not been specifically studied at the extremely high densities found in Chicago's Loop (business district). Although Chicago's high-demand density generally should yield lower per-Btu costs, such density may be associated with greater costs than estimated for this study. Nevertheless, an independent study of a DES concept for a new downtown Chicago residential development project also found the DES to be economically viable. 9

\section{1 FEASIBILITY OF A DES}

To determine the feasibility of DES retrofit, and also to assess the economic viability of such retrofit in relation to varying demand densities, each city was broken down into a workable number of demand zones. City zones were determined by using the principle that areas with the highest demand density would be the first to be retrofitted. This concept was tempered by supply location. For example, an effort was made to bring supply facilities into the city in geographically related clusters, so that main transmission piping could be designed to handle several plants in the same general area. By this zone method, each city could have from three to four independent DES systems that eventually could be tied together.

Although, theoretically, each zone could. operate independently, the total integrated system is much more efficient for two reasons:

(1) As additional zones come on 1 ine, the transmission lines move closer to a closed-loop. When the loop is complete, maximum flexibility for repair and hot water diversion is reached.

(2) Increased supply yields increased flexibility,. In the closed-1oop situation, any supply point from any zone could feed to any demand point within the city area served. 
Table 3.1. Basic Heat Data on Cities Under Study

\begin{tabular}{|c|c|c|c|c|c|c|}
\hline City & $\begin{array}{l}\text { Peak } \\
\text { Demand } \\
\text { MW-Heat }\end{array}$ & $\begin{array}{c}\text { Total City } \\
\text { Area } \\
\left(\mathrm{km}^{2}\right)\end{array}$ & $\begin{array}{l}\text { Area } \\
\text { Covered } \\
\left(\mathrm{km}^{2}\right)\end{array}$ & $\begin{array}{l}\text { Percent } \\
\text { Covered }\end{array}$ & $\begin{array}{l}\text { Average } \\
\text { Demand } \\
\text { MW-Heat }\end{array}$ & $\begin{array}{l}\text { Actual } \\
\text { Plant Supply } \\
\text { MW-Heat }\end{array}$ \\
\hline $\begin{array}{l}\text { Washington } \\
\text { (ANL) }(a)\end{array}$ & 3,174 & 124 & 101 & . 82 & 868 & 5,116 \\
\hline $\begin{array}{l}\text { Washington } \\
(B N L)(a)\end{array}$ & 4,218 & 147 & 143 & 97 & 1,040 & 5,447 \\
\hline St. Louis & 3,426 & 181 & 126 & 70 & 907 & 4,975 \\
\hline Clevel and & 3,989 & 216 & 202 & 94 & 1,226 & 5,995 \\
\hline Milwaukee. & 4,133 & 209 & 193 & 92 & 1,326 & 6,270 \\
\hline Detroit & 5,638 & 382 & 374 & 98 & 1,842 & 8,592 \\
\hline Chicago & 9,066 & 585 & 137 & 23 & 2,525 & 13,300 \\
\hline Boston & 4,149 & 206 & 132 & 64 & 1,117 & 5,368 \\
\hline Baltimore & 5,070 & 283 & 252 & 89 & 1,378 & 6,641 \\
\hline Philade lphia & 9,690 & 344 & 343 & 99 & 2,552 & 11,928 \\
\hline
\end{tabular}

(a) Differences in areas are caused by different district inclusions within the "city". 


\subsection{FLEXIBILITY OF A DES}

The subject of supply flexibility deserves additional discussion. A comparison between a proposed district heating and cooling system and any other central supply option (e.g., all-electric, all-gas) immediately reveals that the DES may not be as flexible as other alternatives. In the case of an all-electric system or all-gas system, an existing interconnect system stretches well beyond the city limits. Electric utilities have the option of purchasing additional power from a grid network, and existing gas distribution lines effectively tie the entire nation's gas supply together. In the case of DES, however, the overall supply is dictated by the maximum capacity of the local supply facilities. This situation can be mitigated by reserve capacity in the form of standby boilers or by conservative estimates of available supply. The former approach is not considered here, but the latter approach is considered in three ways:

(1) Supply requirements are based on peak heating and hot water demands. Obviously, such peak demands will be required for only a small fraction of the time. In other instances, the excess capacity can be considered reserve.

(2) The methods of calculating "available" supply and peak demand were very conservative; thus, a built-in reserve is factored into our calculations. $3^{3}$

(3) In addition to the high reserve factor, a capacity reserve also exists because of hot-water storage in the transmission/distribution pipes.

Table 3.1 shows the nature of such estimates. Available supply is roughly equivalent to peak demand, but is significantly above average demand. Available supply is also only a fraction ( $275 \%$ ) of actual supply producable at the supply point.

Flexibility and reserve increase in going from a zone concept to a city concept. This was shown dramatically in the case of cleveland where Zone III relies exclusively on the Davis-Besse Nuclear Power Plant for its supply. Should Zone III be considered as part of the total DES, any failure of the Davis-Besse plant would result in only a $17 \%$. loss of supply. Although this loss could be serious at a peak period, it could be readily absorbed in most areas.

Although the DES does not have the inherent flexibility of some alternate options, this does not presuppose that an unresolvable problem exists. Certainly, operable. systems in Europe and in certain United States installations have proved that sufficient standby capacity and inherent reliability can be provided to make the DES option viable. Moreover, when a generating unit is removed from the line, this does not automatically shut down the DES. With steam turbine generating units it is possible that a cogenerating unit failure, which causes the electric generating capability to be shut down, can be designed to allow continuous heat production capability. In such an event, an electrical failure would increase the thermal energy available. Only boiler failures (which are extremely rare) would shut down both electrical and thermal capabilities. 
The DES system considered here covers only the energy supplied to provide space heating and hot water. Conceptually, a DES may provide either heating or cooling. Cooling can be provided by using an absorption chiller. However, such a device is relatively inefficient, and its low expected efficiencies indicate that, in most cases, less energy would be utilized by generating electricity to run compression chillers than by using DES to generate heat for an absorption chiller.6,10,11 This property of a DES limited the scope of this report to areas dominated by heating load. Although demand assessments were made for cooling needs, the proposed DES does not envision supplying heat for cooling. Thus, the overall economics are based on heat load only.

On the surface, efficiencies would indicate that absorption chillers would not be extensively utilized; nevertheless, certain supply. components of the DES warrant a second look. Specifically, heat generated by boilers or gas turbines is low cost in that very little electrical capacity is given up to obtain heat for absorption chillers.6,12,13 Heat generated in such a manner conceivably could prove more economical than compression chillers. Although not covered here, an optimization analysis of the cooling potential of a DES arrants serious consideration.

The DES in this report uses a two-pipe system (one feed, one return) for the transmission of the heat-exchange medium. In this case, the medium is hot water at $200^{\circ} \mathrm{F}$. The hot water so distributed $c$ an be used in various ways that would cause greater or lesser retrofit costs within the end-user buildings. To be totally accurate, an assessment of the specific end-use heating mechanisms in every building type would be required; however, such an assessment is beyond the scope of this report, and the end-use retrofit costs used here generally assume that $200^{\circ} \mathrm{F}$ water could be used directly as a heatexchange medium after a heat exchanger has been retrofitted to existing buildings. These retrofit costs, based on estimates compiled by Burns $\&$ Roe for buildings currently using steam or hot water systems, 14 are considered too high. 


\subsection{DEMAND ESTIMATES}

In this section the derivation of total building energy demands is discussed. Although the methods used by the ANL/ESCOR and BNL/ESRG study groups differ substantially, the aggregate demand estimates for the one common city (when service areas are made identical) are within three percent for average demands. The major differences occur for peak demands, where the ANL/ESCOR estimate is $27 \%$ less than the BNL/ESRG estimate. The major area of difference between the disaggregate estimates of energy demand by the two groups occurs in the commercial/institutional (office building) category. The BNL/ESRG demand estimates. for this type of building are based on an unpublished study completed for DOE by Arthur D. Little, Inc. The ANL/ESCOR estimates are based on a comparison of three published studies by three independent consulting firms working for two independent sponsors.15,16,17 In general, the ANL/ESCOR demand estimates are based on comparison of more sources than the BNL/ESRG estimates and are more oriented to the specific attributes of the demand area. The ANL/ESCOR effort also represents a larger proportion of the cities studied for this project: As a result, this section describes only the ANL/ESCOR demand estimation methodology. Those readers interested in more detail about either of the two methods are referred to the earlier semi-independent ANL/ESCOR and BNL/ESRG studies 1,2,3,6 The demand values presented later in this section are a result of these two independent methods and have not been reconciled for this study. In view of the similar average heating demands for Washington, D.C., reconciliation of the averages should not make much difference. However, since, in the ANL/ESCOR study group's opinion, the BNL/ESRG peak demand estimates are high, the BNL/ESRG capital equipment requirements to meet peak demand are excessive and lead to cost estimates biased on the high side. A discussion of the demand estimation technique used by ANL/ESCOR follows.

\subsubsection{ANL/ESCOR Heating/Cooling Demand Determination}

To determine the demand (either heating or cooling) the following two basic parameters were estimated:

(1) the number of square feet of floor space to be served, and

(2) the amount of energy needed to satisfy the needs in each square foot.

Obviously, different types of building space will have different energy needs; thus an assessment of space by various categories must be determined Although many building type breakdowns theoretically are desirable, this study considers only the following four basic building categories:

(1) Low-density-residential -- defined as single-family houses, townhouses, and two- to three-story apartment huildings (but dominated in the service areas by the latter two); 
(2) high-density residential -- defined as high rise apartment houses;

(3) commercial/institutional buildings -- defined as highrise office buildings, hospitals, schools, etc.; and

(4) industmial buildings -- defined as urban type multistory industrial complexes, rather than land-intensive

- industry.

Suburban land-intensive development including single-family homes, shopping centers, and manufacturing, generally are not included in the areas served by the DES in this study. Areas of a city that contained more than $75 \%$ single-family residences were eliminated. This is consistent with previous data demonstrating the lower economic viability of utilizing DES in such areas. 18

The square footage per building type was estimated by Real Estate Research Corporation by compiling data from various planning and city agencies and disaggregating the data according to $\mathrm{km}^{2}$ grid lines corresponding to the Universal Transverse Mercator Grid $\left(\mathrm{km}^{2}\right)$ for all cities, except Chicago. The Chicago estimates were based on one-square-mile grids that have been used in previous Argonne work. 19 Residential square footage generally was gleaned from U.S. Census estimates of dwelling units in census tracts. 20 Commercial and institutional, as well as industrial data on square footage were not as readily available. Various sources of information were used to estimate the square footage in such buildings (see Appendix in Ref. 1).

Although the above data were collected for the entire city under study, the zone concept, and the fact that only a percentage of a city was served by our DES (See Table 3.1) dictated which square kilometer grid data would be used in our demand estimates. Table 4.1 details the square footage used by building classification in each city under study.

As we have alluded to in earlier paragraphs, the building categories were selected on the basis of the probability that they would be found in the service area and the attributes of their energy use profiles. 21 For example, the location of high-rise commercial buildings in the central business districts (CBDs) allowed omission in this study of the more energy-consuming shopping-center type of retail store. This is allowable because of our knowledge that DES will be mostly concentrated in the CBDs.*

Residential energy demand per square foot was based mostly on data generated by contacts in the Washington, D.C., area. Data were provided from actual gas meter readings of low-denstiy residential units. Two years of data were available, and a good estimate of daily heating demand was obtained. Actual meter readings, corrected by a furnace efficiency factor of $67 \%$, gave an estimate of energy used. The data generated for Washington, D.C., were compared to previous studies of residential energy use. Findings of 15.06

*This procedure will underestimate commercial energy demands outside of CBDs. 
Table 4.1. City Building Square Footage $\left(\mathrm{ft}^{2} \times 10^{3}\right)$

\begin{tabular}{|c|c|c|c|c|}
\hline City & $\begin{array}{l}\text { Low Density } \\
\text { Residential }\end{array}$ & $\begin{array}{l}\text { High-Density } \\
\text { Residential }\end{array}$ & $\begin{array}{c}\text { Commercial } \\
\text { Institutional }\end{array}$ & Industrial \\
\hline $\begin{array}{l}\text { Washington } \\
\quad(\text { ANL) }\end{array}$ & (a) & 295,325 (a) & 159,916 & 13,022 \\
\hline $\begin{array}{l}\text { Washington } \\
\text { (BNL) }\end{array}$ & (a) & $347,000(a)$ & 180,000 & 13,300 \\
\hline St. Louis & (a) & $243,706(a)$ & 77,243 & 59,946 \\
\hline Clevel and & 259,408 & 68,667 & 41,460 & 78,410 \\
\hline Mi lwaukee & 241,208 & 57,715 & 59,044 & 43,981 \\
\hline Detroit & 452,792 & 36,620 & 77,714 & 70,104 \\
\hline Chicago & 409,752 & 120,058 & 335,475 & 227,077 \\
\hline Boston & 104,000 & $196,000^{(b)}$ & 100,000 & 63,700 \\
\hline Baltimore & 422,000 & 17,900 & 198,100 & 86,700 \\
\hline Philadelphia & 732,000 & 53,300 & 184,000 & 185,000 \\
\hline
\end{tabular}

(a)Figures in High Density Residential Row for Washington and St. Louis are the sum of $\mathrm{R}-1$ and $\mathrm{R}-2$ (RLD, RHD).

(b) The Boston HD/LD mix given by RERC results from a different breakdown than in other cities. The high-density cutoff was at a lower density.

$\mathrm{Btu} / \mathrm{ft}^{2} \mathrm{x}$ HDD corresponded well enough with previous efforts $\left(14.6 \mathrm{Btu} / \mathrm{ft}^{2}\right.$ $x$ HDD) that it seemed safe to use an equation relating energy usage with Heating Degree Days, HDD, to estimate energy usage in other cities.8,22

When the average day value is found, and an equation is accepted for other cities, an estimate of peak heat usage was generated by utilizing the ASHRAE $97.5 \%$ design temperatures. 23 For example, for Washington, D.C., ANL estimated the $97.5 \%$ design temperature to be $19^{\circ} \mathrm{F}$, and the peak heat load would be $14.6 \mathrm{Btu} / \mathrm{ft}^{2} \mathrm{x}$ day $\mathrm{x}{ }^{\circ} \mathrm{F} \times\left(65^{\circ}-19^{\circ}\right)=671.6 \mathrm{Btu} / \mathrm{ft}^{2} \mathrm{x}$ day. Because of other factors (e.g., diversity) the use of a $97.5 \%$ design temperature rather than a $99 \%$ value is appropriate for use in this study.

Data for high-rise residential buildings were less available, so an assumption was made that this classification would behave in essentially the same way as low-density residential as regards seasonal variations of climate. However, the actual usage of energy would be only a fraction of that used in low-density residential. The factor used to correlate high to low density residential was 0.72 . This factor was assumed to apply fairly consistently for not only average heating but also for peak heating and cooling. The utilization of this factor in conjunction with the transfer equation for average heating loads in various cities allows an analysis of peak heat load of residential units in cilies under consideration. 
Estimates of commercial/institutional ( $/ \mathrm{I}$ ) building heat uses were derived from an outgrowth of earlier work. Analysis of such work indicated that much of this classification was office space and that other types of $\mathrm{C} / \mathrm{I}$ buildings had amounts of energy usage that straddled office energy usage. Based on such findings, it seemed reasonable to assume that the office building can be used as a good surrogate for the overall energy consumption behavior in central business districts.15,16 An equation, dependent on heating degree days, was formulated to estimate the commercial energy usage per square foot.

As is true for $\mathrm{C} / \mathrm{I}$ buildings, a lack of first-hand data exists for industrial building energy consumption. Even with good data, this class of floor space would be difficult to describe generically because it represents a highly variable class of energy consumer. Nevertheless, it is possible to characterize the downtown industrial energy consumer with some degree of confidence. A generalized assumption made was that $C B D$ industry will behave somewhat similarly to the $\mathrm{C} / I$ classification with the major difference being more usage per day because of shift operations. The only recognized data available (IDHA study) would indicate a ratio of $\mathrm{C} / \mathrm{I}$ to industrial usage of $1: 1.18 .24$ Although the lack of validation of this ratio is recognized; it does fit the assumption made above, and thus was used as a transfer function for deriving industrial energy usage as related to $\mathrm{C} / \mathrm{I}$ usage. Downtown areas, which are likely to be served first by a DES, have much more C/I floor space than industrial facilities. Industry tends to be more dispersed through the city than is commercial activity.

Hot-water usage is assumed to be a function of occupancy levels rather than square footage, and thus hot-water usage varies by occupancy levels assumed for each building type. Previous works provide insights into residential hot-water usage 22 A value of $22 \mathrm{Btu} / \mathrm{ft}^{2}$-day was generated for lowdensity, residential hot-water usage. To arrive at hot-water usage in highdensity residential, a surrogate comparison of rooms per unit in high- vs low-density residential was utilized for hot-water consumption. C/I hot-water usage was based on work by the BNL/ESRG study group 22; whereas, industrial hot-water usage was scaled up from $\mathrm{C} / \mathrm{I}$ in the same way heating demand was scaled.

Having both the square foot age available by $\mathrm{km}^{2}$ (or $\mathrm{mi}^{2}$ for Chicago) in each city and the per-square-foot energy demands, energy demand can be determined. Table 4.2 depicts the per-square-foot factors for the total city. The above information allowed estimation of various data on a $\mathrm{km}^{2}$ basis. These data were computerized to permit the design of transmission lines that would serve clusters of demand from various supply points. Such information also allowed fairly accurate estimates of local distribution and building retrofit costs.

Differences between the ANL/ESCOR and BNL/ESRG demands for Washington, D.C. (see. Table 4.2), are caused by: (1) the different districts being included into the four ANL/ESCOR demand zones and the three BNL/ESRG demand zones; (2) the different demand/ft ${ }^{2}$ factors, and (3) the BNL/ESRG service area having slightly greater estimated residential and commercial/institutional building square footage. The latter factor is primarily responsible for the increased average energy demands and costs in the BNL/ESRG calculations. 
Table 4.2. Energy Demand Factors (Btu/ft. ${ }^{2}$ day)

\begin{tabular}{|c|c|c|c|c|}
\hline City & $\begin{array}{l}\text { Low Density } \\
\text { Residential }\end{array}$ & $\begin{array}{r}\text { High Density } \\
\text { Residential }\end{array}$ & $\begin{array}{l}\text { Comm./ } \\
\text { Inst it. }\end{array}$ & Industrial \\
\hline \multicolumn{5}{|l|}{ Washington (ANL) } \\
\hline $\begin{array}{l}\text { Average Day Heat } \\
\text { Peak Day Heat } \\
\text { Hot Water }\end{array}$ & $\begin{array}{r}168 \\
672 \\
22\end{array}$ & $\begin{array}{r}121 \\
484 \\
15\end{array}$ & $\begin{array}{r}85 \\
339 \\
9\end{array}$ & $\begin{array}{r}95 \\
380 \\
11\end{array}$ \\
\hline \multicolumn{5}{|l|}{ Washington (BNL) } \\
\hline $\begin{array}{l}\text { Average Day Heat } \\
\text { Peak Day Heat } \\
\text { Hot Water }\end{array}$ & $\begin{array}{r}134 \\
556 \\
36\end{array}$ & $\begin{array}{r}96 \\
400 \\
27\end{array}$ & $\begin{array}{r}151 \\
630 \\
8\end{array}$ & $\begin{array}{r}103 \\
430 \\
5\end{array}$ \\
\hline \multicolumn{5}{|l|}{ St. Louis } \\
\hline $\begin{array}{l}\text { Average Day. Heat } \\
\text { Peak Day Heat } \\
\text { Hot Water }\end{array}$ & $\begin{array}{r}190 \\
788 \\
22\end{array}$ & $\begin{array}{r}137 \\
568 \\
15\end{array}$ & $\begin{array}{r}96 \\
398 \\
9\end{array}$ & $\begin{array}{r}113 \\
470 \\
11\end{array}$ \\
\hline \multicolumn{5}{|l|}{ Cleveland } \\
\hline $\begin{array}{l}\text { Average Day Heat } \\
\text { Peak Day Heat } \\
\text { Hot Water }\end{array}$ & $\begin{array}{r}246 \\
847 \\
22\end{array}$ & $\begin{array}{r}177 \\
610 \\
15\end{array}$ & $\begin{array}{r}124 \\
427 \\
9\end{array}$ & $\begin{array}{r}147 \\
504 \\
11\end{array}$ \\
\hline \multicolumn{5}{|l|}{ Milwaukee } \\
\hline $\begin{array}{l}\text { Average Day Heat } \\
\text { Peak Day heat } \\
\text { Hot Water }\end{array}$ & $\begin{array}{r}298 \\
978 \\
22\end{array}$ & $\begin{array}{r}215 \\
704 \\
15\end{array}$ & $\begin{array}{r}150 \\
494 \\
9\end{array}$ & $\begin{array}{r}175 \\
583 \\
11\end{array}$ \\
\hline \multicolumn{5}{|l|}{ Detroit } \\
\hline $\begin{array}{l}\text { Average Day Heat } \\
\text { Peak Day Heat } \\
\text { Hot Water }\end{array}$ & $\begin{array}{r}257 \\
832 \\
22\end{array}$ & $\begin{array}{r}185 \\
599 \\
15\end{array}$ & $\begin{array}{r}130 \\
420 \\
9\end{array}$ & $\begin{array}{r}153 \\
496 \\
11\end{array}$ \\
\hline \multicolumn{5}{|l|}{ Chicago } \\
\hline $\begin{array}{l}\text { Average Day Heat } \\
\text { Peak Day Heat } \\
\text { Hot Water. }\end{array}$ & $\begin{array}{r}245 \\
934 \\
22\end{array}$ & $\begin{array}{r}176 \\
673 \\
15\end{array}$ & $\begin{array}{r}124 \\
472 \\
9\end{array}$ & $\begin{array}{r}146 \\
557 \\
11\end{array}$ \\
\hline \multicolumn{5}{|l|}{ Boston } \\
\hline $\begin{array}{l}\text { Average Day Heat } \\
\text { reak Day Heat } \\
\text { Hot Water }\end{array}$ & $\begin{array}{r}181 \\
639 \\
33\end{array}$ & $\begin{array}{r}154 \\
561 \\
27\end{array}$ & $\begin{array}{r}185 \\
670 \\
10\end{array}$ & $\begin{array}{r}138 \\
502 \\
5\end{array}$ \\
\hline \multicolumn{5}{|l|}{ Baltimore } \\
\hline $\begin{array}{l}\text { Average Day Heat } \\
\text { Peak Day Heat } \\
\text { Hot Water }\end{array}$ & $\begin{array}{r}163 \\
605 \\
38\end{array}$ & $\begin{array}{r}119 \\
441 \\
27\end{array}$ & $\begin{array}{r}153 \\
566 \\
9\end{array}$ & $\begin{array}{r}116 \\
429 \\
5\end{array}$ \\
\hline \multicolumn{5}{|l|}{ Philadelphia } \\
\hline $\begin{array}{l}\text { Average Day Heat. } \\
\text { Peak Day Heat } \\
\text { Hot Water }\end{array}$ & $\begin{array}{r}165 \\
629 \\
38\end{array}$ & $\begin{array}{r}112 \\
430 \\
27\end{array}$ & $\begin{array}{r}165 \\
632 \\
9\end{array}$ & $\begin{array}{r}119 \\
456 \\
5\end{array}$ \\
\hline
\end{tabular}


To summarize, each $\mathrm{km}^{2}$ (or $\mathrm{mi}^{2}$ ) is provided with the following information:

- low-density residential, $\mathrm{ft}^{2}$

- high-density residential, $\mathrm{ft}^{2}$

- commercial/institutional, $\mathrm{f}^{2}$

- industrial,

- peak heating demand, Btu/day

- average heating demand, Btu/day

- hot water demand, Btu/day

An example of energy density distribution patterns is shown in Fig. 4.1. Although this particular display applies only to Washington, D.C. (ANL/ESCOR) residential heat plus hot water, a eimilar display is available for each energy category, building category, or for appropriate combinations thereof.* Energy distribution patterns for Washington, D.C. (BNL/ESRG), St. Louis, Cleveland, Milwaukee, Detroit, Chicago, Boston, Baltimore, and Philadelphia are given in Figs. 4.2 through 4.10 , respectively.

\subsection{ENERGY SUPPLY ANALYSIS}

Having arrived at estimates for energy demand, the next task in this study was to assess energy supply. The basic supply criteria followed when demand exceeded supply to retrofit a city until available cogeneration supply was exhausted. These criteria were breached in two cities when new thermal. boilers were introduced. This was done when supply and demand were nearly balanced and when existing district heating boiler stations were available. In the case of Chicago, an extremely large amount of new capacity would be required to retrofit the entire city. Consequently, only a portion of Chicago is served. The selection of this portion was not optimized but merely based on incremental expansion around the Loop (CBD).

In almost all cases, supply was derived from existing electric generating or thermal plants. Close analysis of generic systems (see Refs. 13 and 25-35) revealed that there are five basic ways in which supply may be btained:

(1) condensing pressure and extraction volume increase retrofit on existing single-stage turbines (CPEI);

(2) intermediate cross-over extraction retrofit on existing multi-stage turbines ( $\mathrm{CO}$ );

(3) recuperator retrofit on existing gas turbines ( $R C$ );

(4) conversion of existing steam boilers or installation of new hot water boilers (B); and

(5) installation of new specifically manufactured variable steam-extraction turbines.

*Information on peak and average cooling also was available but was not used in this study. 


\section{HEAT + HOT WATER}

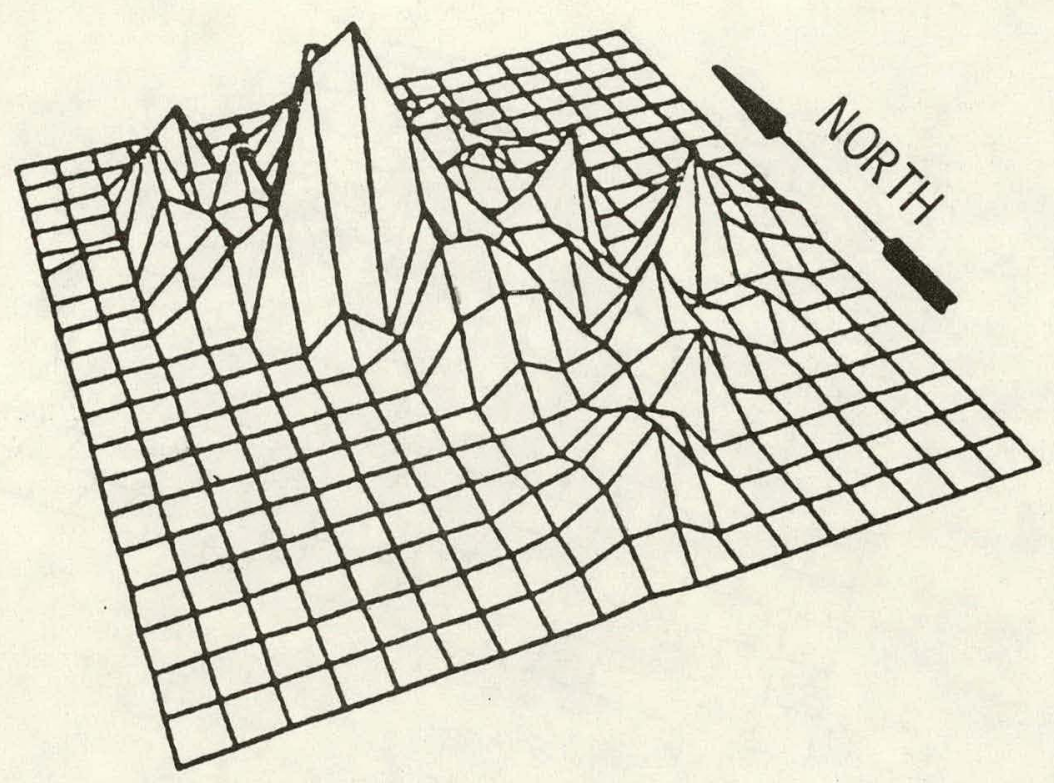

ONE SQUARE $=1$ SQ. KM.

Fig. 4.1. Average Day Heat Demand Profile -- Washington, D.C. (ANL/ESCOR) 


\section{HEAT + HOT WATER}

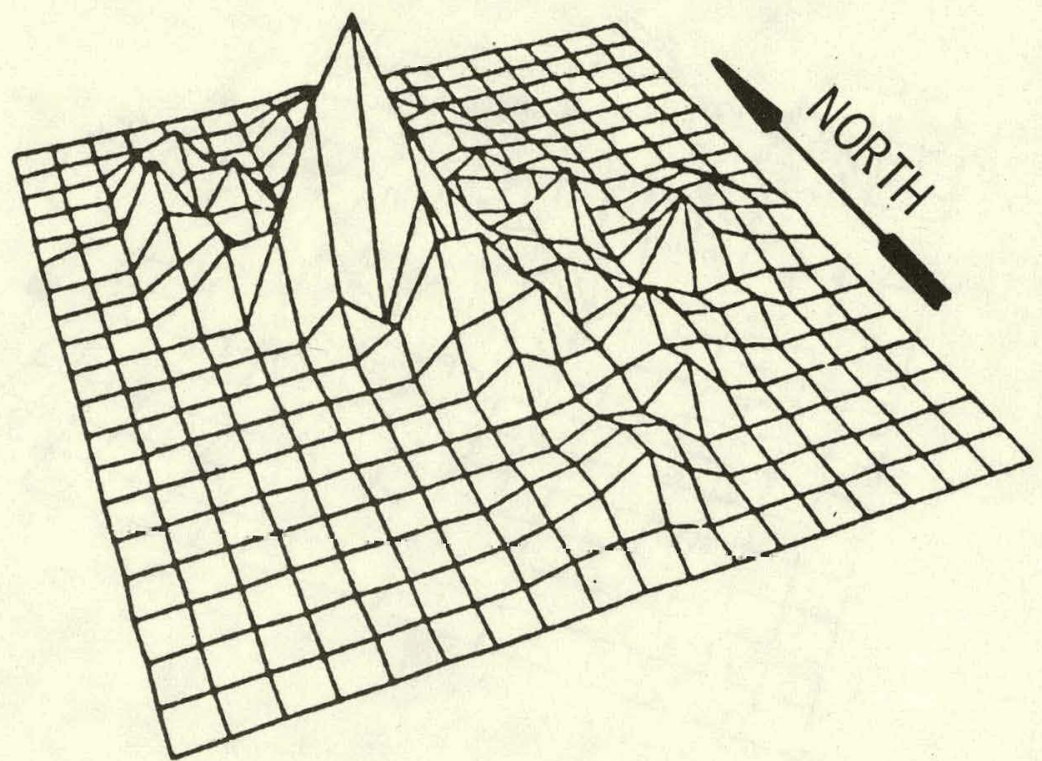

ONE SQUARE $=1$ SQ. KM.

Fig. 4.2. Average Day Heat Demand Profile for Washington, D.C. (BNL/ESRG) 


\section{HEAT + HOT WATER}

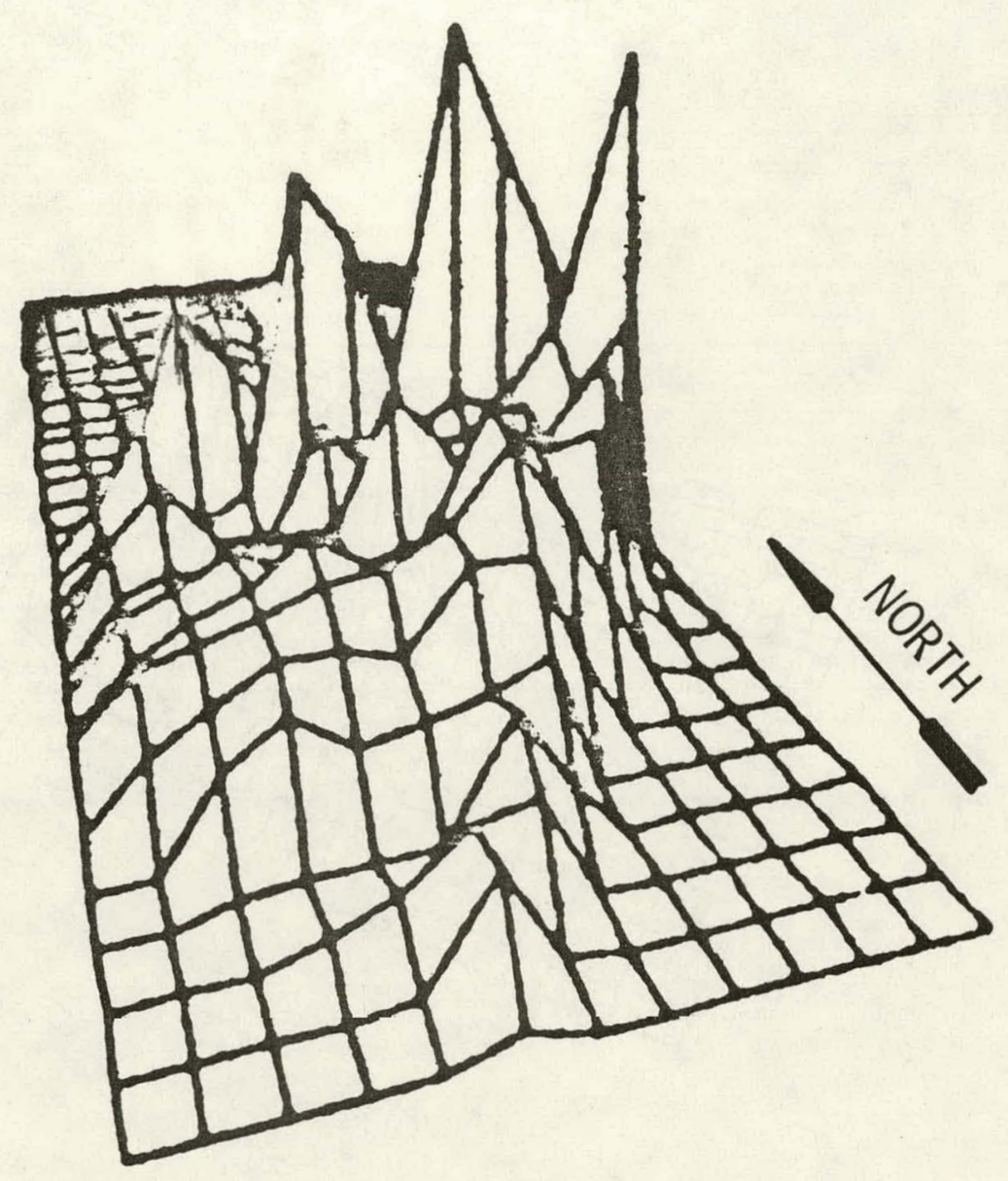

ONE SQUARE = 1 SQ. KM.

FIg. 4.3. Average Day Heat Demand Profile -- St. Louis 


\section{HEAT + HOT WATER}

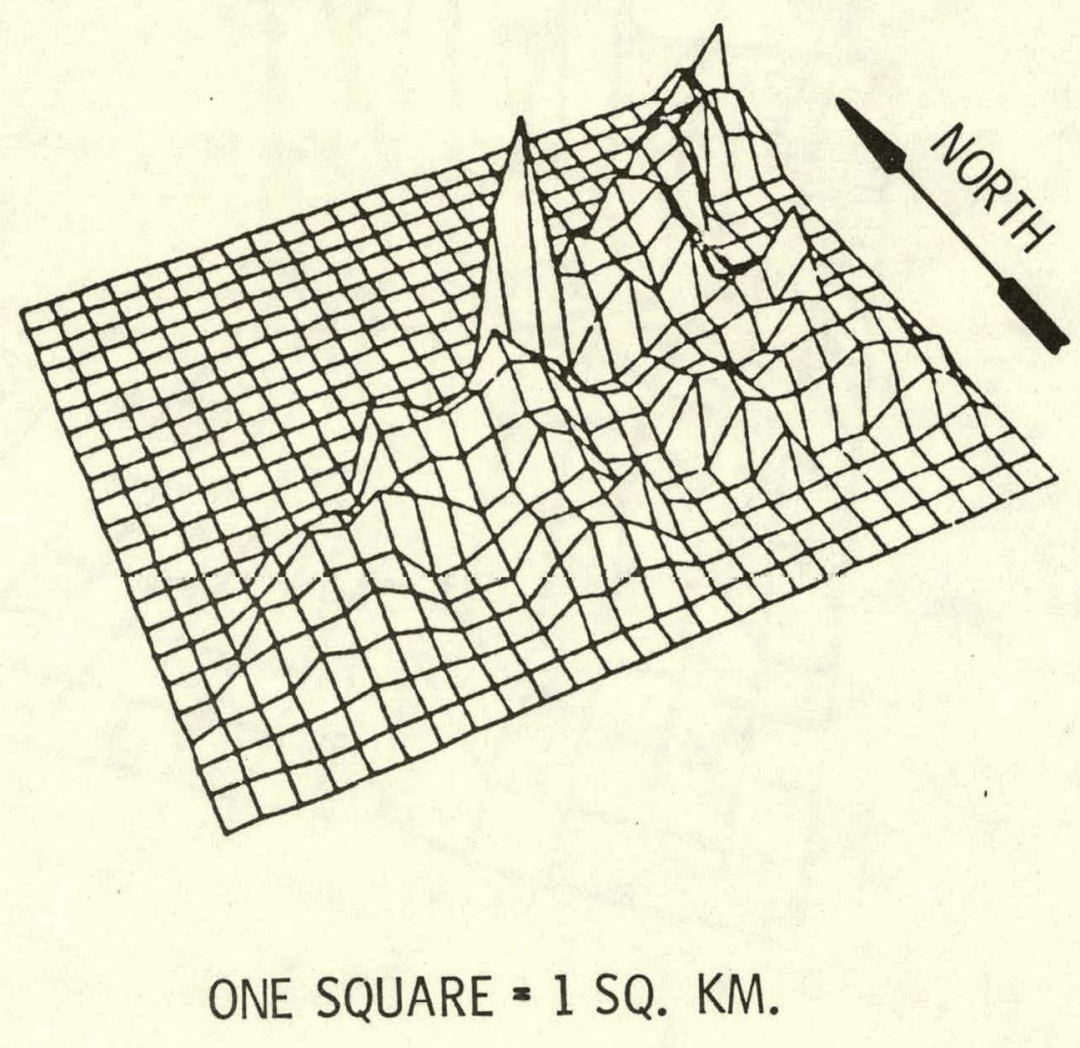

Fig. 4.4. Average Day Heat Demand Profile -- Cleveland 
HEAT + HOT WATER

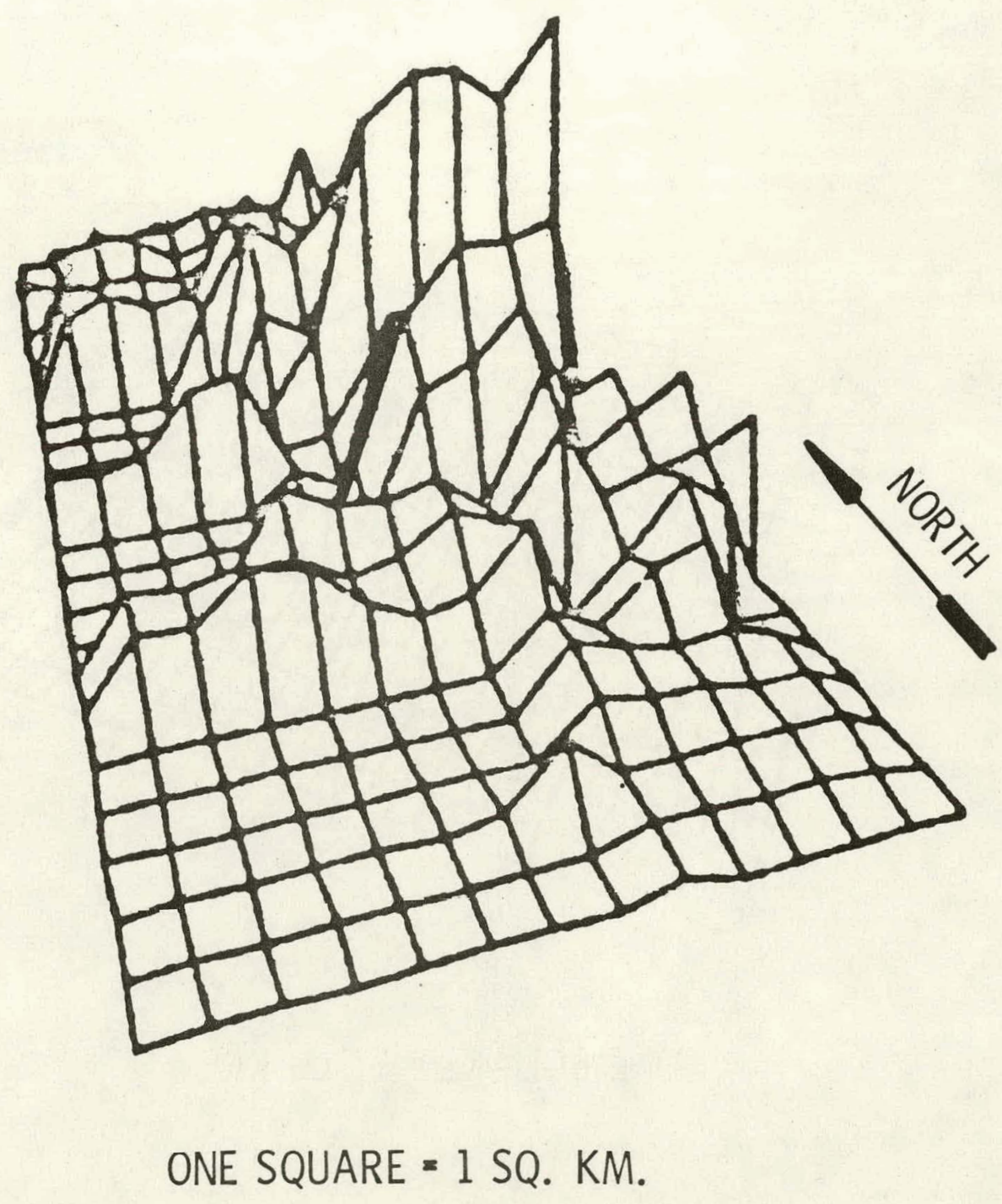

Fig. 4.5. Average Day Heat Demand Profile -- Milwaukee 


\section{HEAT + HOT WATER}

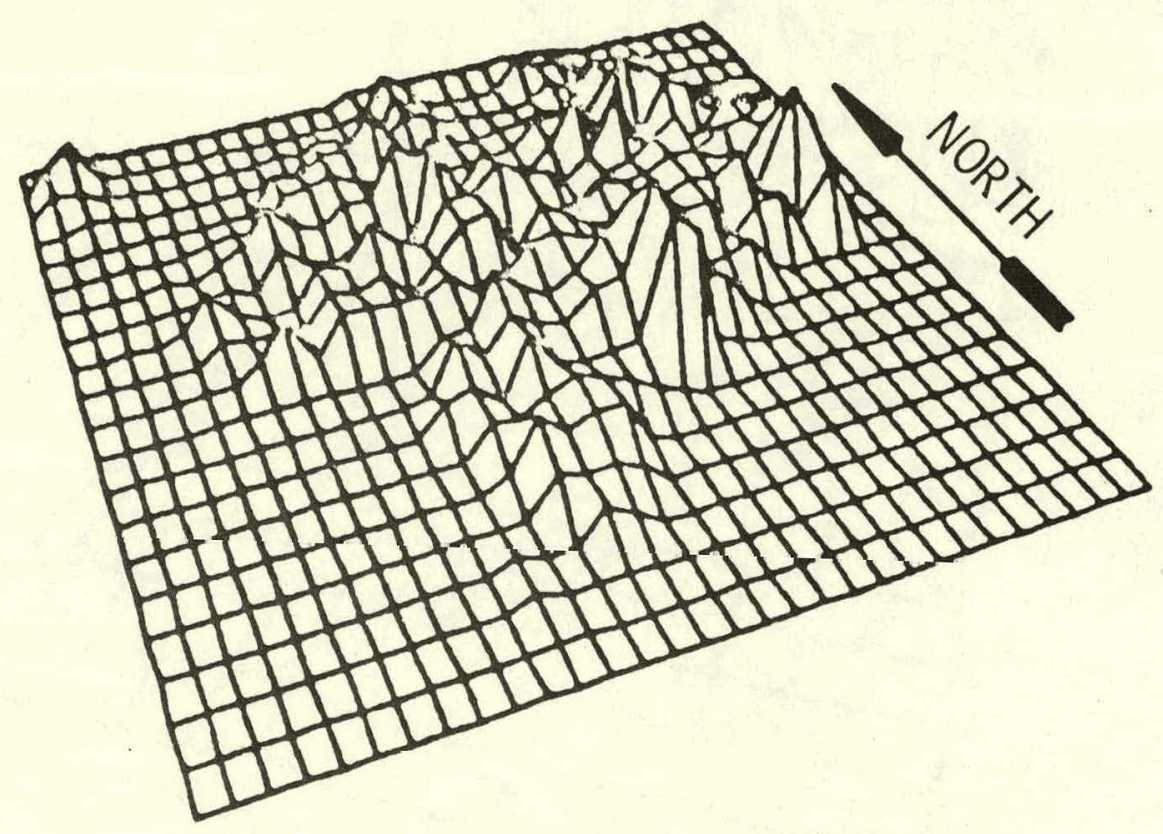

ONE SQUARE = 1 SQ. KM.

Fig. 4.6. Average Day Heat Demand Profile -- Detroit 
HEAT + HOT WATER

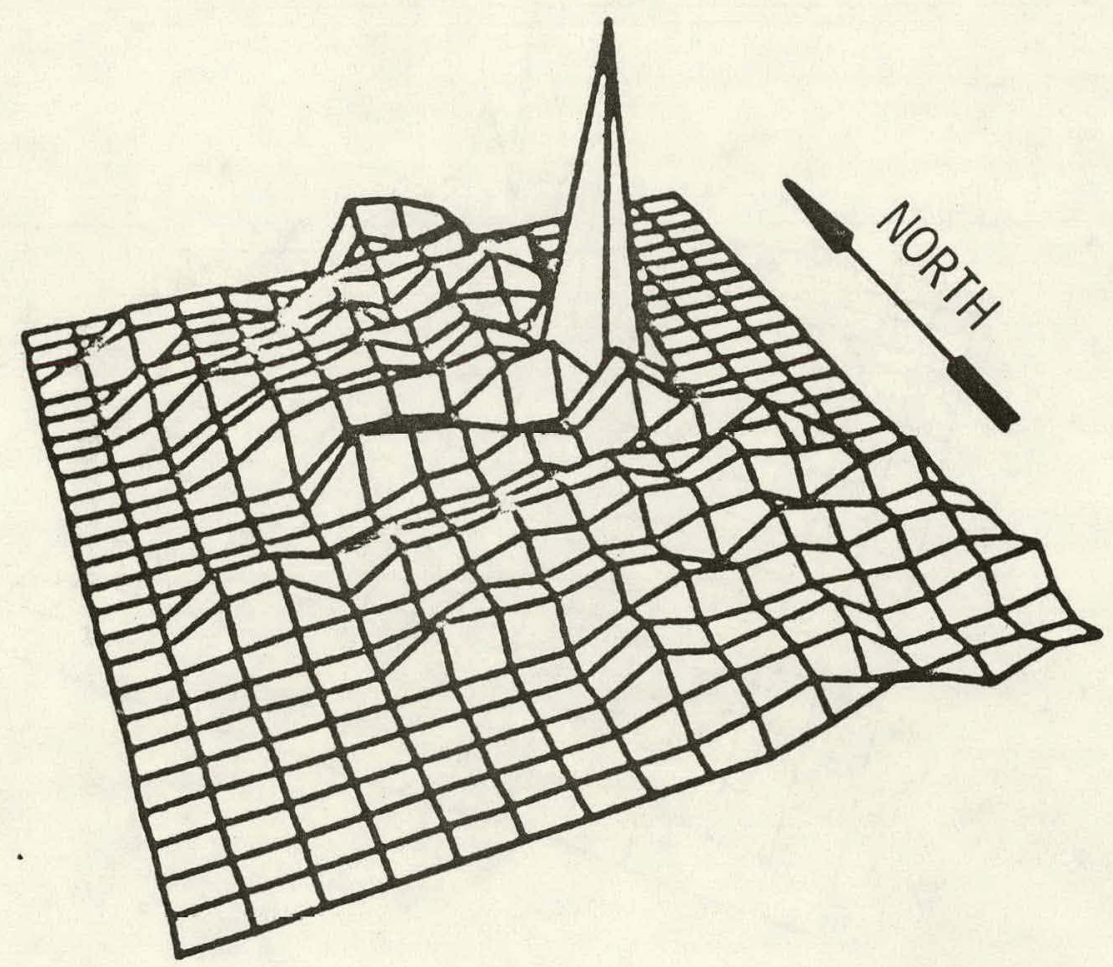

ONE SQUARE $=1$ SQ. MI.

Fig. 4.7. Average Day Heat Demand Profile -- Chicago 


\section{HEAT + HOT WATER}

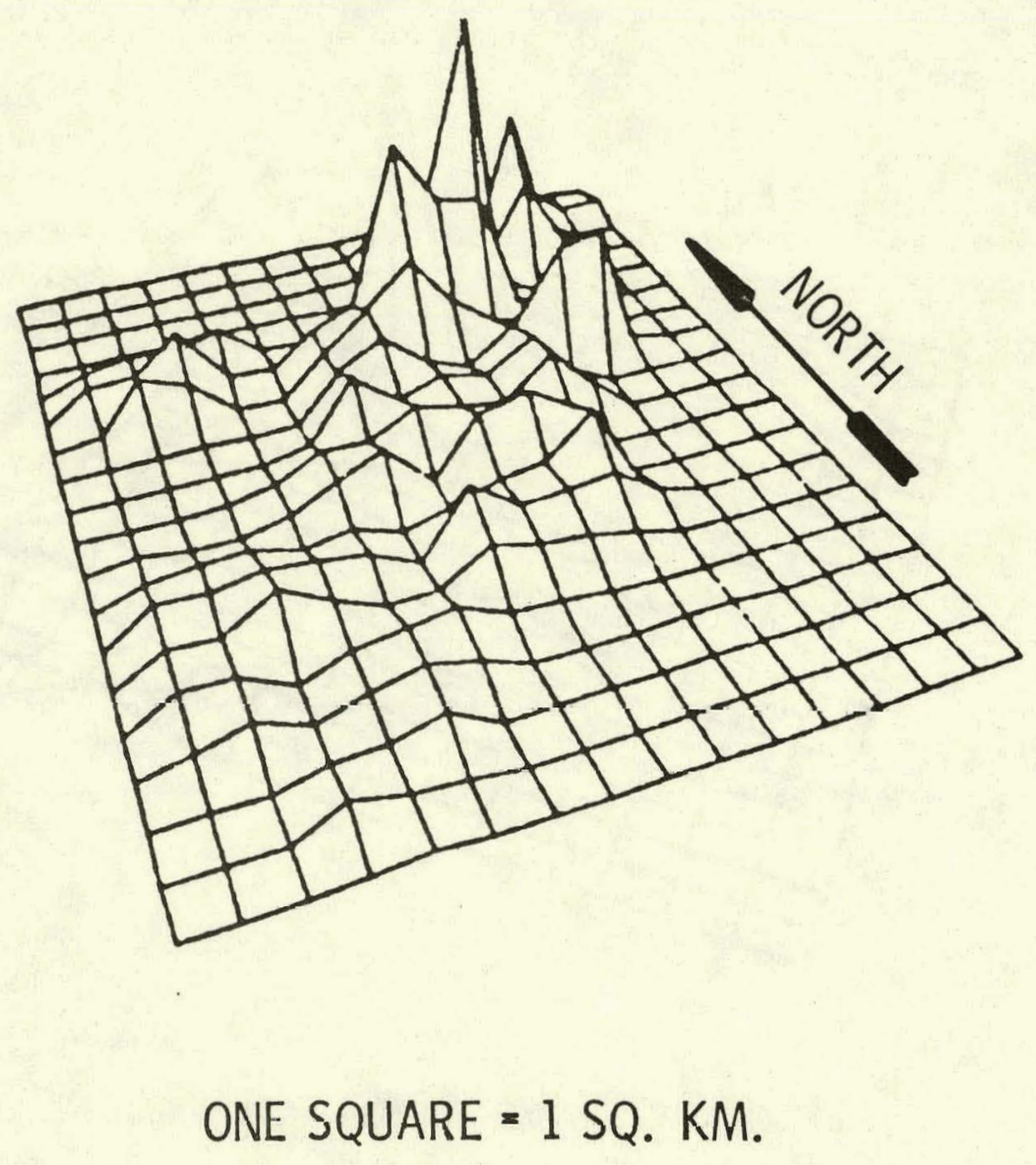

Fig. 4.8. Average Day Heat Demand Profile -- Boston 


\section{HEAT + HOT WATER}

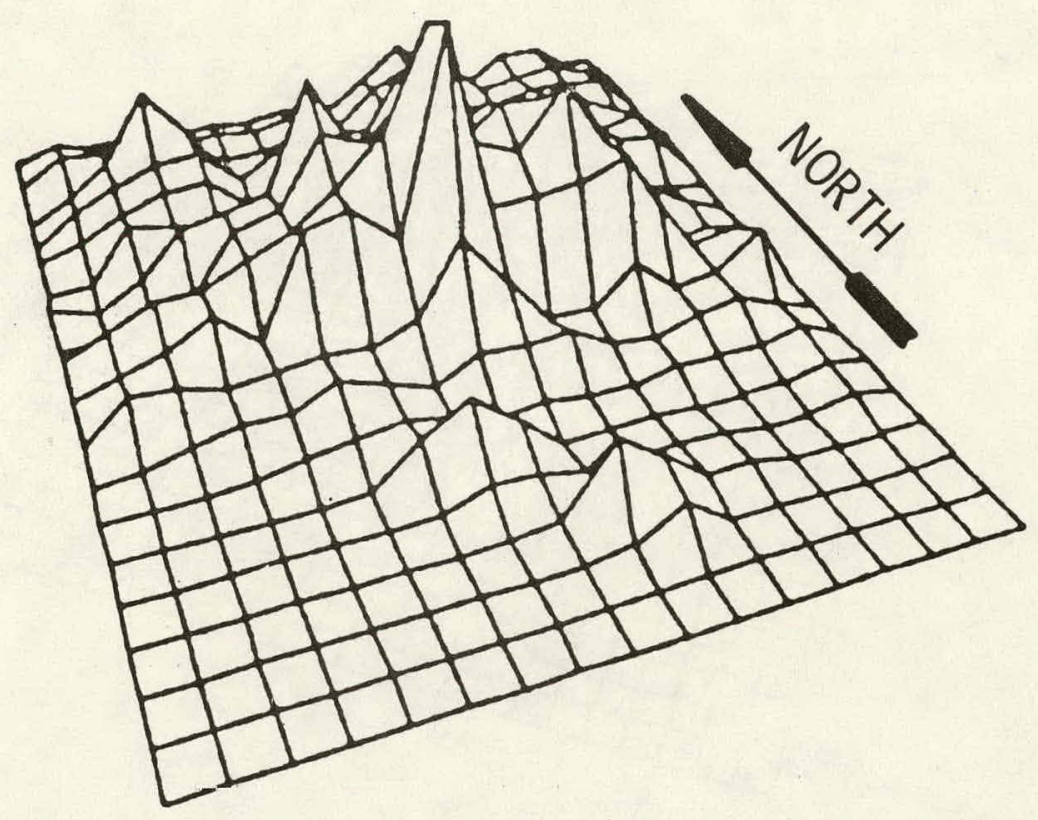

ONE SQUARE $=1$ SQ. KM.

Fig. 4.9. Average Day Heat Demand Profile -- Baltimore 


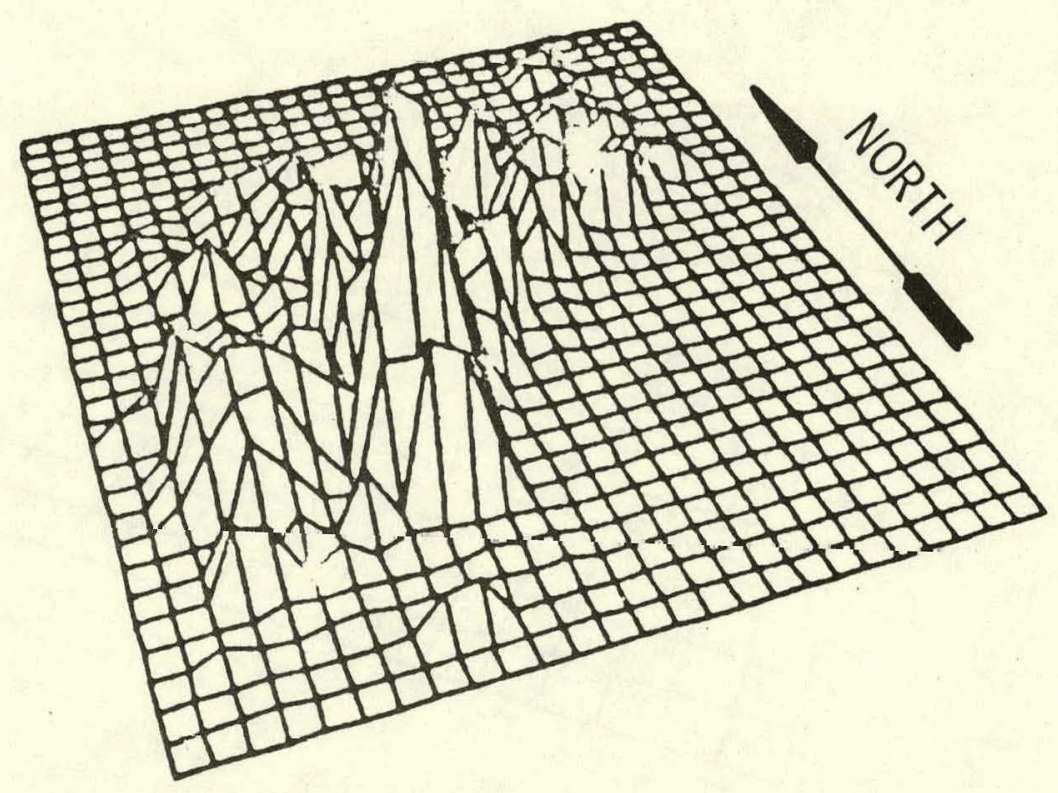

ONE SQUARE $=1$ SQ. KM.

Fig. 4.10. Average Day Heat Demand Profile -- Philadelphia 
A11 of the above options except (5) were utilized many times in the five North-Central and three Northeast cities during this study.* The new turbine option was used in only the methodology development case of Washington, D.C., as a substitute for a planned generating unit. 6 This last was used in both the ANL/ESCOR and BNL/ESRG studies.

Ideally, the analysis of a specific system would require a detailed evaluation of each unit. However, a detailed study of specific generic units and a comparison of those results with installed capacity indicated that individualized study was not required. Generic studies performed resulted in sufficiently accurate thermodynamic estimates such that the results were applied to all units in that classification (see Appendix A). Table 4.3 depicts the results of such analyses. The heat and electric megawatt power of various units, as shown in Table 4.3, served as the basis for supply selection. Retrofit of steam turbines results in a substantial loss in electric generating capacity, but this loss is more than recovered in heat power. Nevertheless, the electric capacity lost should be made up so that the electric utility will still be able to satisfy its peak demand. Replacement capacity is figured into overall costs as will be explained later.

Retrofit of existing gas turbines reaps large overall increases in power. These increases occur as a result of heat energy from waste heat in the exhaust gas, and not from decreased feed to the turbine. Unfortunately, gas turbines are peak units and thus are the last units to be brought on line

Table 4.3. Results of Existing Retrofit Options

\begin{tabular}{ccccc}
\hline $\begin{array}{c}\text { Initial Power } \\
\text { Type Unit } \\
\text { (MW) }\end{array}$ & $\begin{array}{c}\text { Retrofit } \\
\text { Option }\end{array}$ & $\begin{array}{c}\text { Elec. Power } \\
\text { after Retro- } \\
\text { fit (MW) }\end{array}$ & $\begin{array}{r}\text { Heat Power } \\
\text { after Retro- } \\
\text { fit (MW) }\end{array}$ & $\begin{array}{r}\text { Total Power } \\
\text { after Retro- } \\
\text { fit (MW) }\end{array}$ \\
\hline 30-Turbine & CPEI & 14.7 & 55.8 & 70.5 \\
60-Turbine & CPEI & 31.6 & 104.6 & 136.2 \\
100-Turbine & CPEI & 64.8 & 143.4 & 208.2 \\
60-Turbine & CO & 45 & 75 & 120 \\
100-Turbine & CO & 70 & 130 & 200 \\
120-Turbine & CO & 90 & 150 & 240 \\
200-Turbine & CO & 145 & 255 & 400 \\
62-Gas Turbine & RC & 56 & 125 & 181 \\
\hline
\end{tabular}

* Subsequent analysis has shown that option (5) should have been used when making up for electrical capacity lost because of cogeneration. 
when operated optimally (from the electrical point of view). This study, in generating supply, attempts to keep plant electrical load factors at least proportionate to what they were before retrofit.

Information on specific units of generating facilities was obtained with the assistance of the major utilities in each city's service areas. This information provided the necessary data from which to cluster supply points and, hence, energy demands to be serviced from each point.

When the total available heat energy was established, corrections were made to account for capacity factors and system losses. Generally, an overall capacity factor of 0.75 , and a loss factor of 0.9 were used. Thus, a gross energy supply of $1000 \mathrm{MW}$ is used to satisfy a net energy demand at the building face of $675 \mathrm{MW}$.

A11 the above information allows a match of peak demand and supply by zone. Supply points were selected to serve the most dense demand zones first Each square kilometer was rated with regard to peak heating plus hot water demands. Thermal supply was brought into the city by means of transmission pipes that were designed to carry the hot water gallonage required by selected groups of $\mathrm{km}^{2}$ (demand zones).36-44 Transmission pipes followed major rights-of-way, and an attempt was made to bring the main trunk directly into the center city. Some trial and error was necessary to arrive at the exact boundaries of a particular zone, the major criteria being that the demand should not exceed the supply by more than 5\%. For example, for St. Louis, the demands of zones one and three exceeded supply by $7.9 \%$ and $5.1 \%$, respectively. In zones two and four, supply exceeded demand by $6.1 \%$ and $2.8 \%$, respectively. Overall the peak demand exceeded potential supply (adjusted for reserves and losses) by only $2.0 \%$.

A secondary consideration in determining demand boundaries was an awareness of local distribution costs. An attempt was made to locate transmission lines so that the local distribution pipeline would not have to extend more than two $\mathrm{km}$ in any direction. Although this criterion could not be met at all times, it was met in most cases.

Figures $4.11(\mathrm{a}, \mathrm{b})$ to 4.19 display the results of the zone selection criteria. As can be seen from a study of theses figures and Figs. 4.1 to 4.10, zones were added in order of decreasing demand. Zone I covers the main downtown business district; whereas, Zones II and III are always adjacent to that district. The area not covered was of lower demand density and remained after supply was exhausted. Figures 4.11 to 4.20 also reveal the basic adherence to the transmission piping loop concept. Although individual zone transmission pipes terminate at approximate zone lines, the rinal piping creates a closed loop. This allows supply from any point to serve any demand sector. Each transmission line actually is two lines. The DES under consideration here is a hot water system in which supply and return 1 ines are both provided.

\subsection{COMPONENT CAPITAL COSTS ESTIMATES}

A knowledge of supply requirements to meet estimated demand allows for a more detailed analysis of costs involved. Each cost component was analyzed 


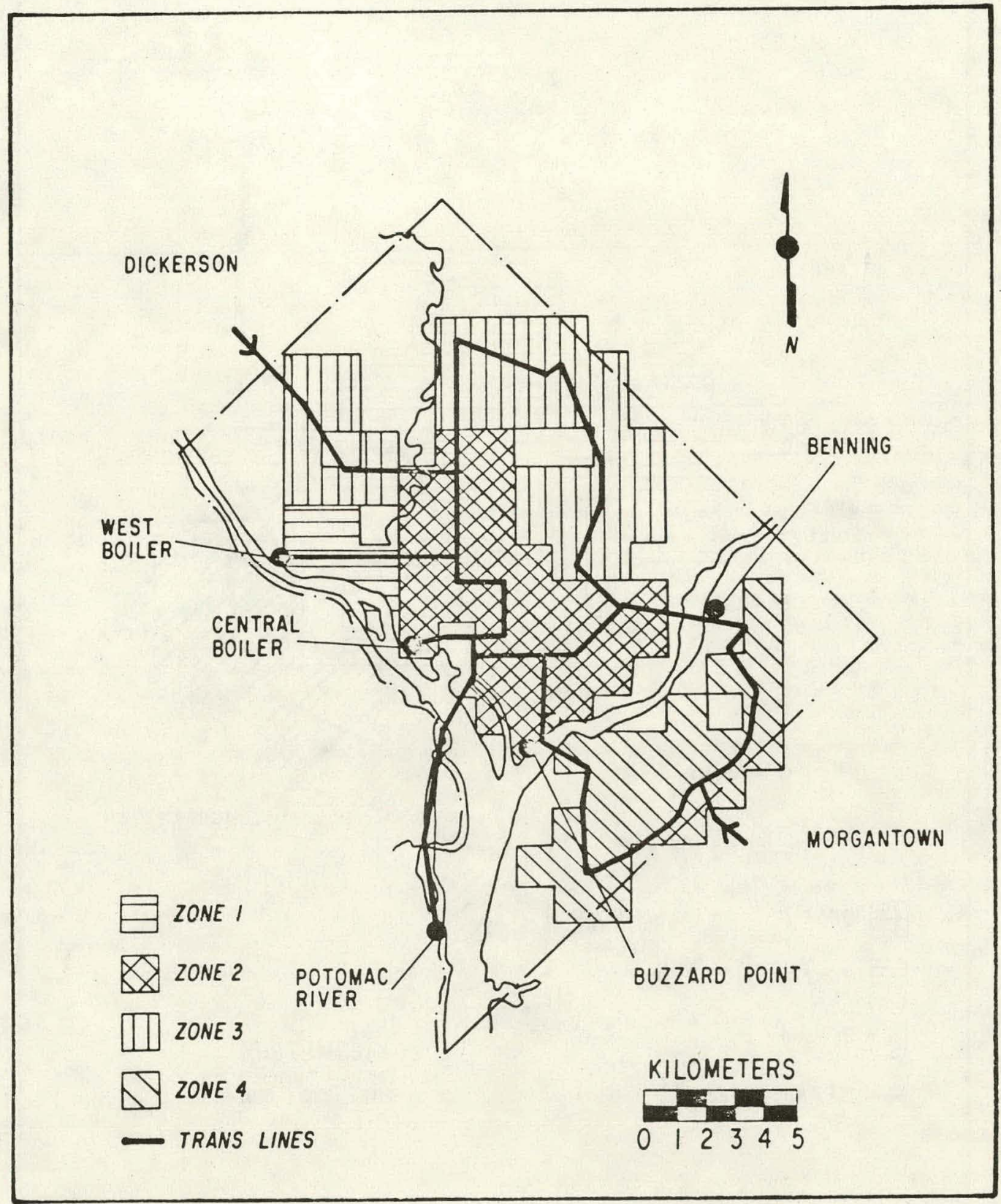

Fig. 4.11. Washington, D.C. -- Demand Zone \& Supply Lines (ANL/ESCOR) 


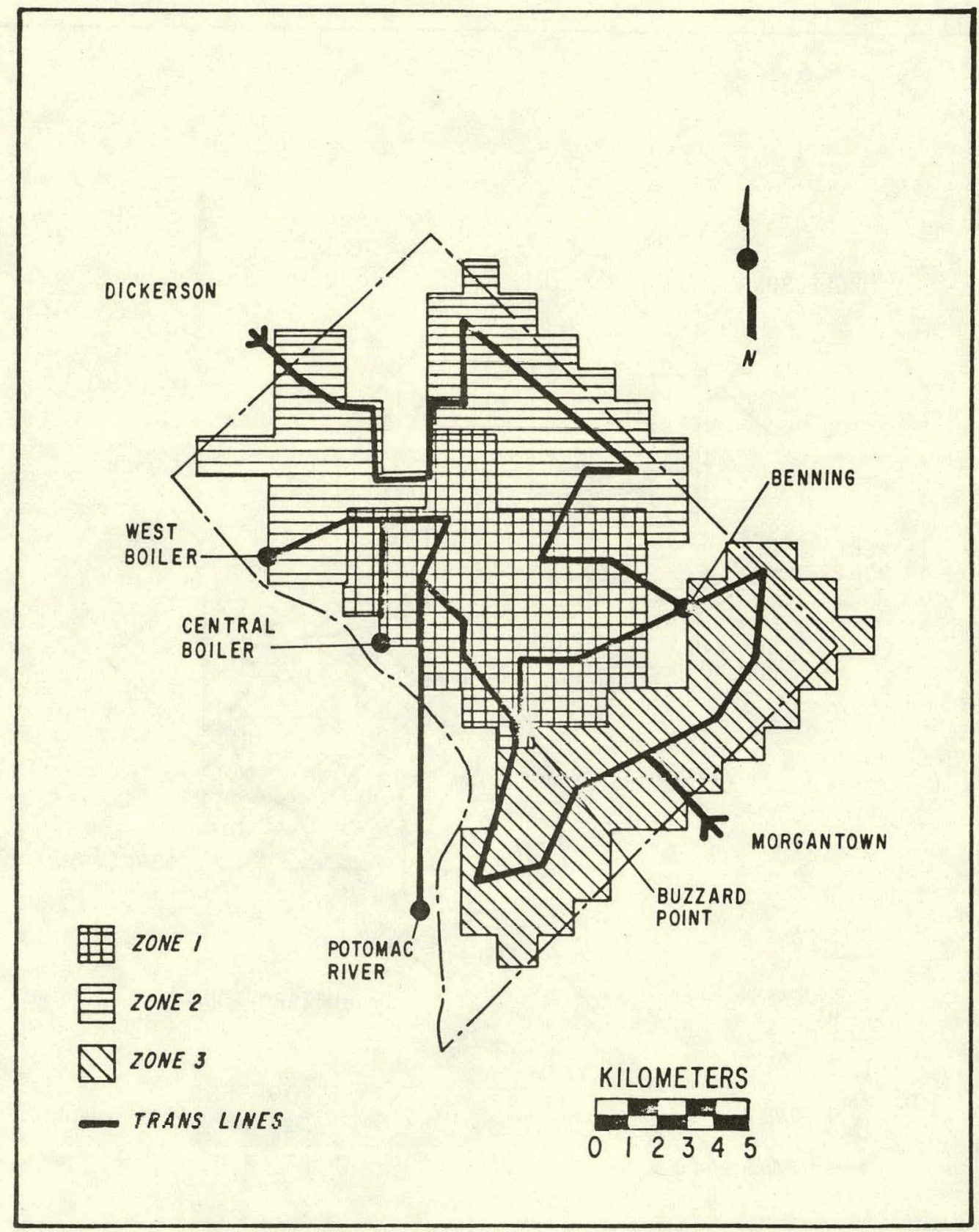

Fig. 4.12. Washington, D.C. -- Demand Zones \& Supply Lines (BNL/ESRG) 


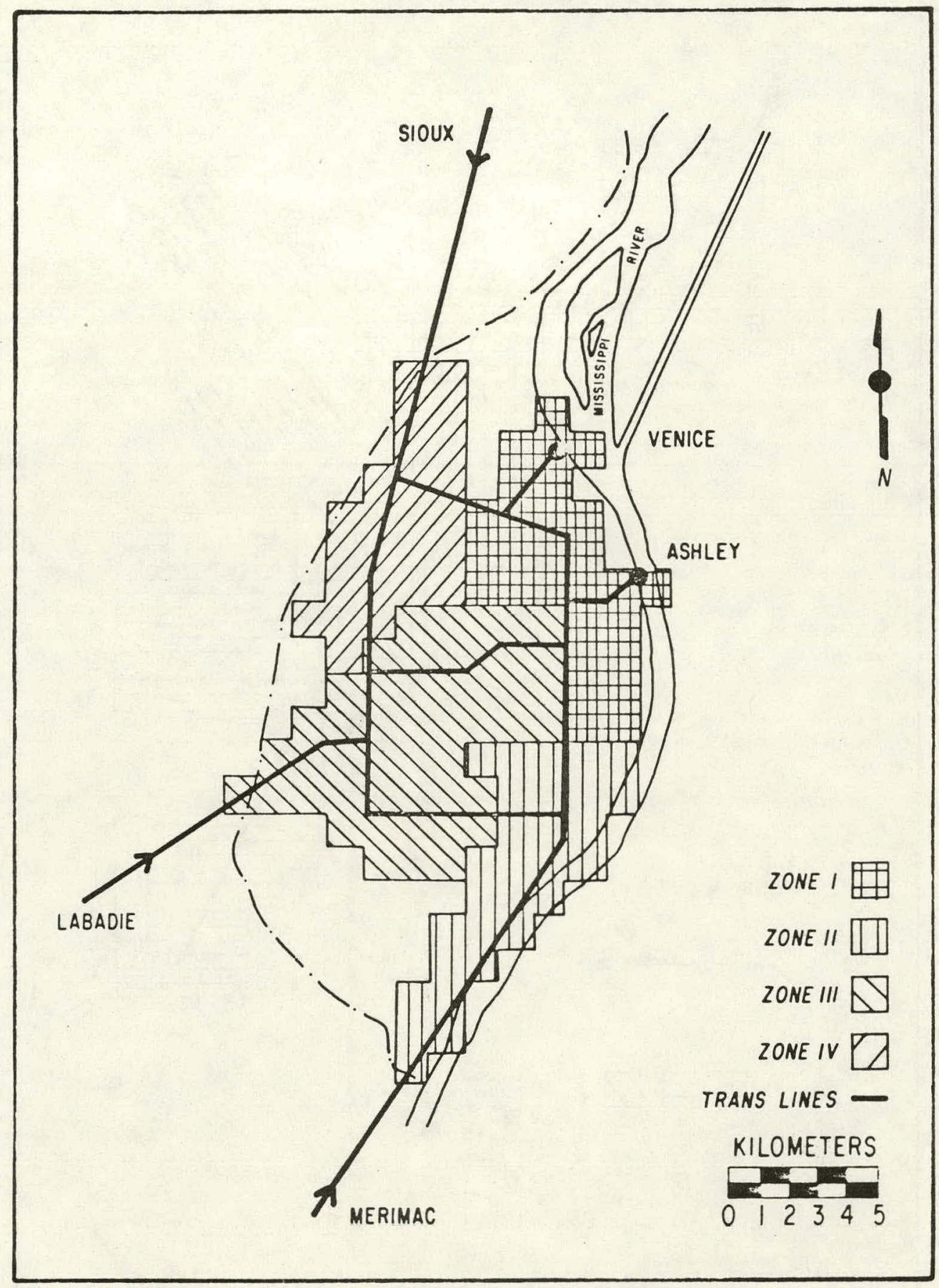

Fig. 4.13. St. Louis -- Demand Zones \& Supply Lines 


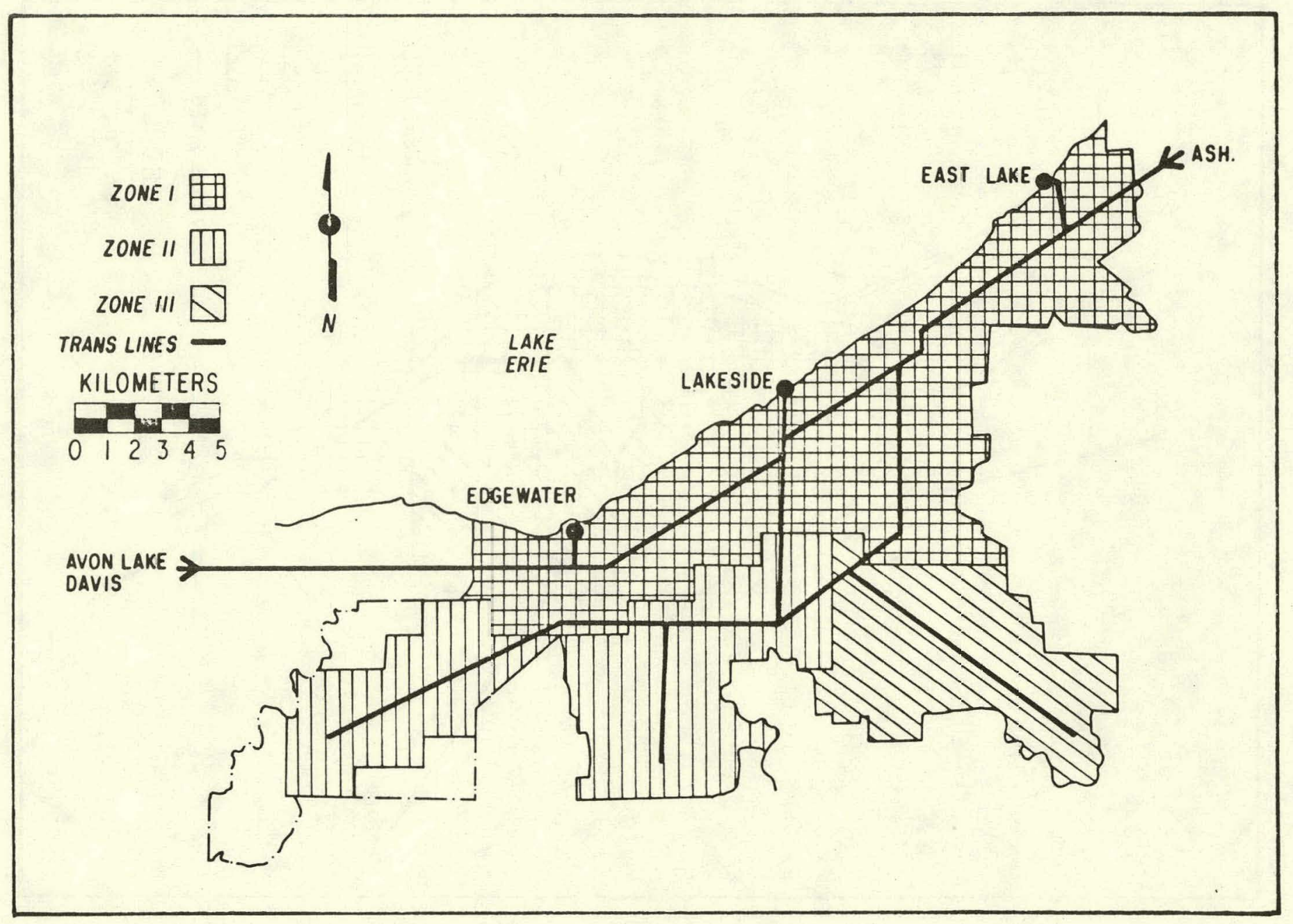

Fig. 4.14. Cleveland -- Demand Zones and Supply Lines 


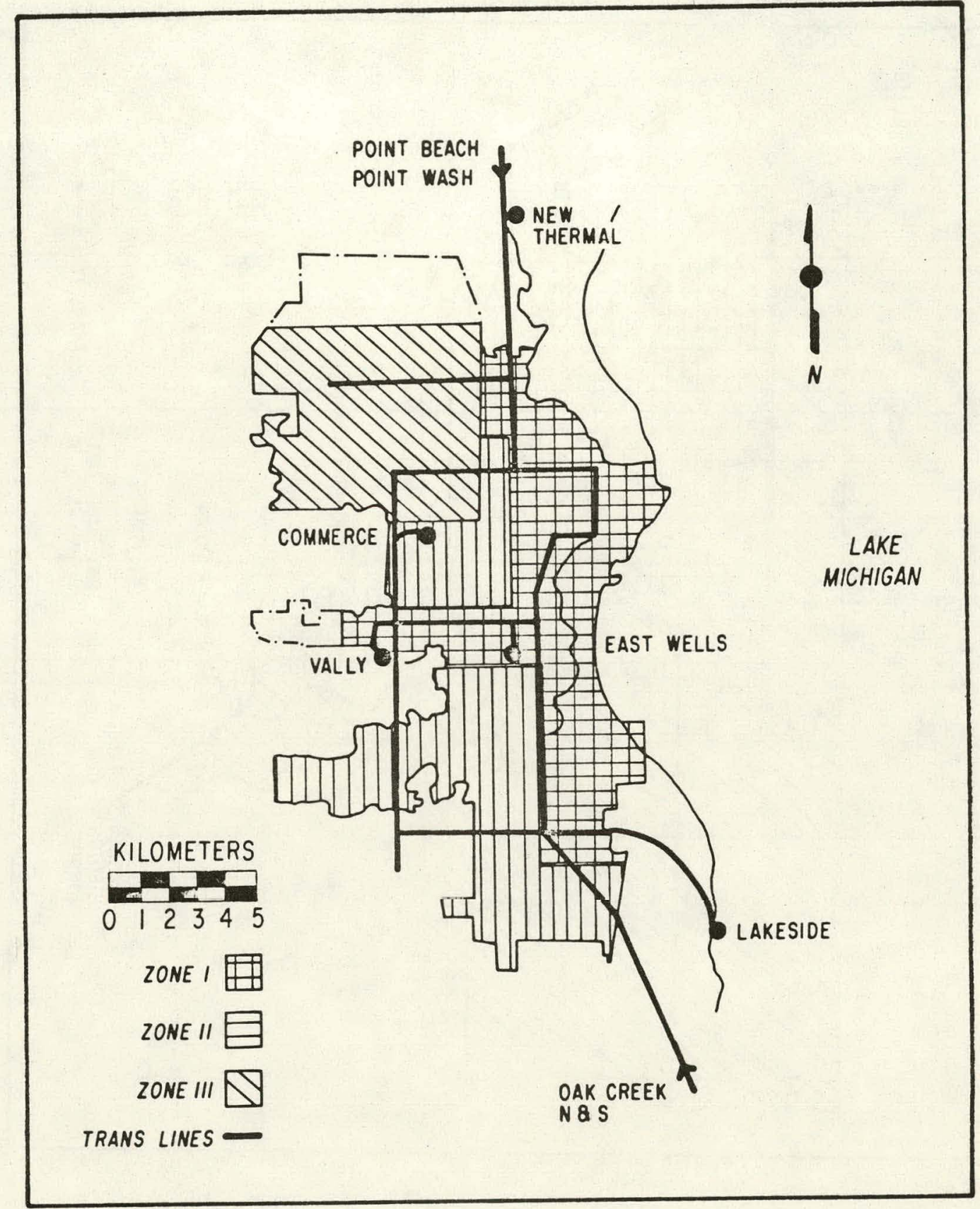

Fig. 4.15. Milwaukee -- Demand Zones and Supply Lines 


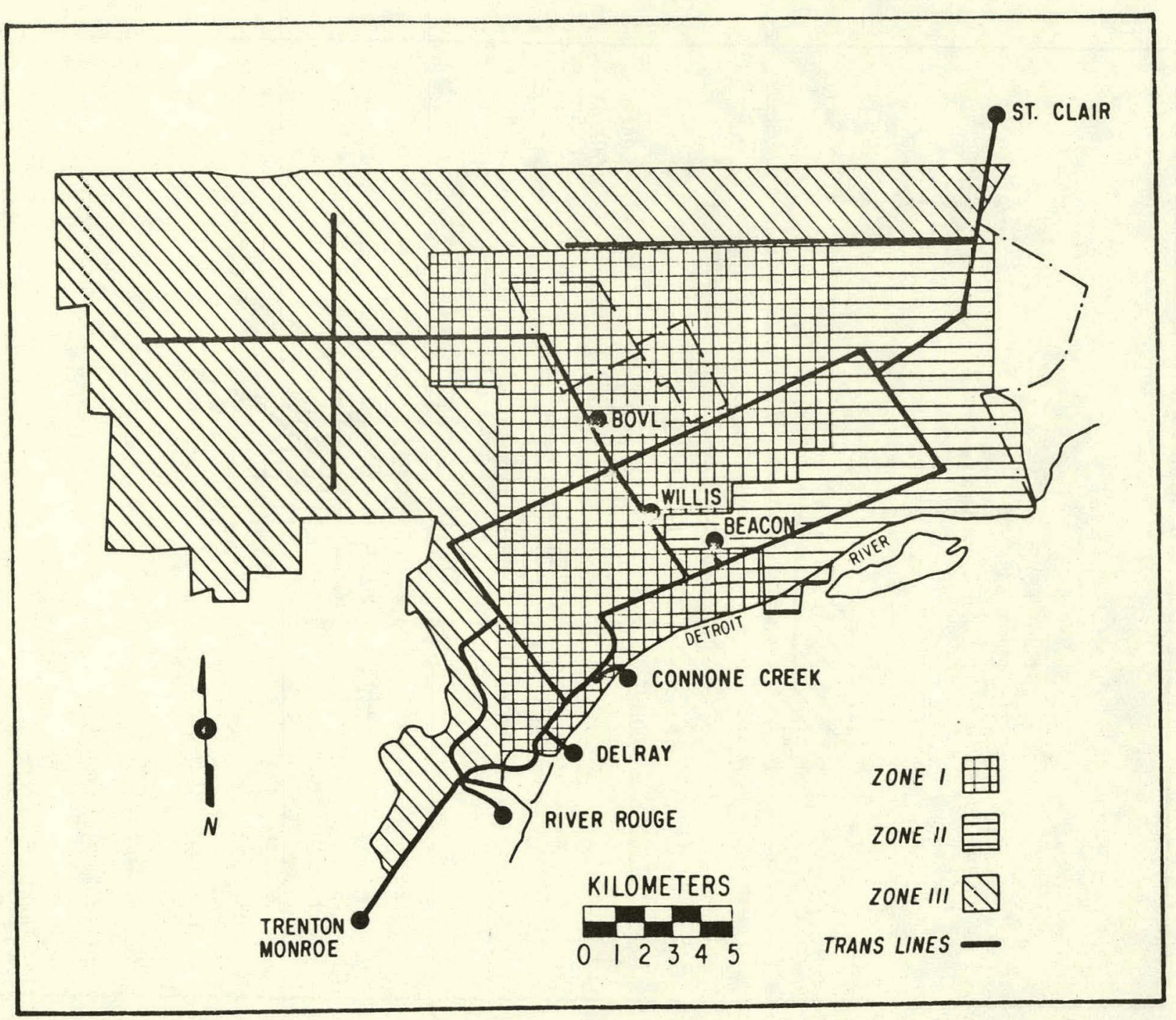

Fig. 4.16. Detroit -- Demand Zones and Supply Lines 


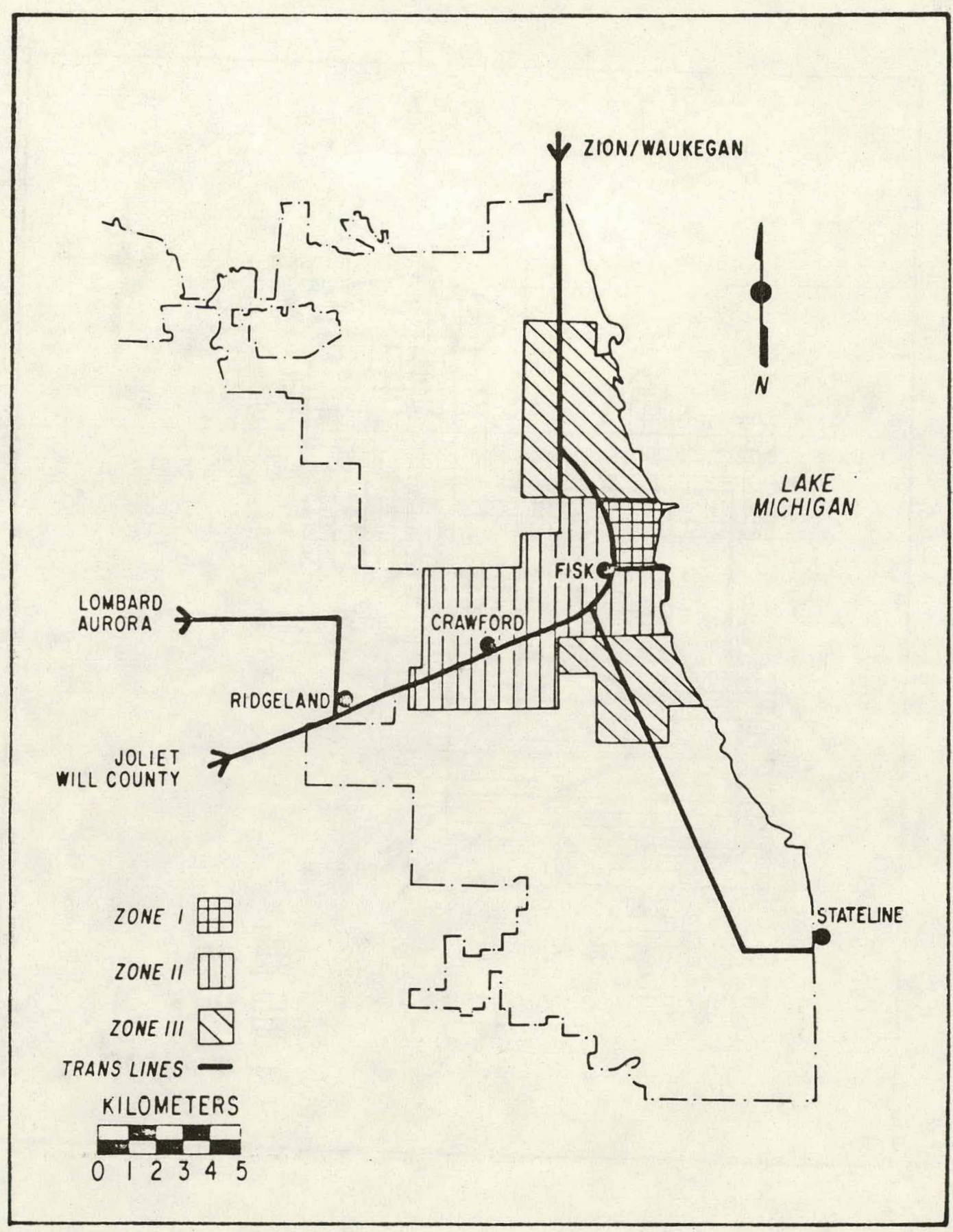

Fig. 4.17. Chicago - Demand Zones and Supply Lines 


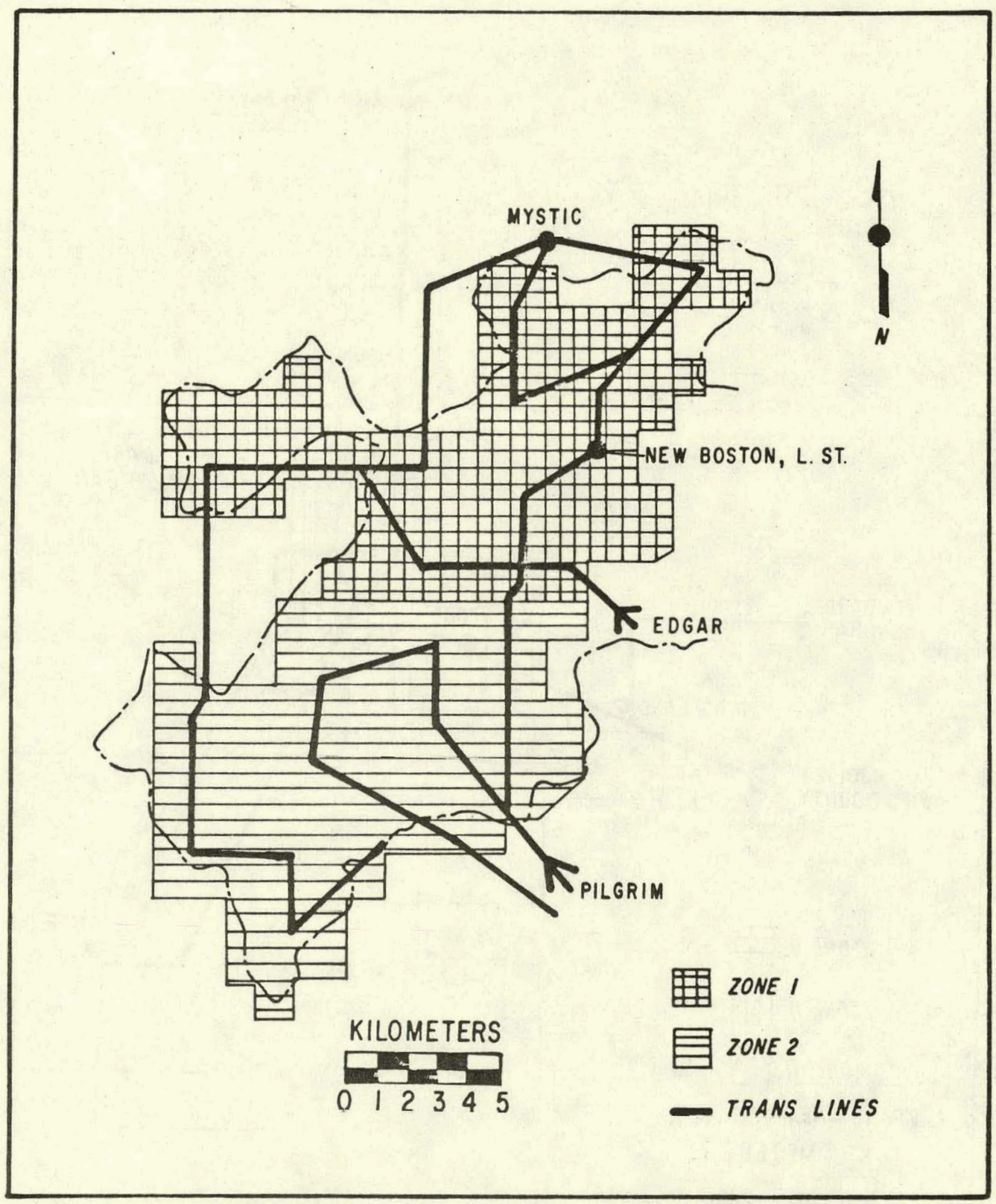

Fig. 4.18. Boston -- Demand Zones and Supply Lines 


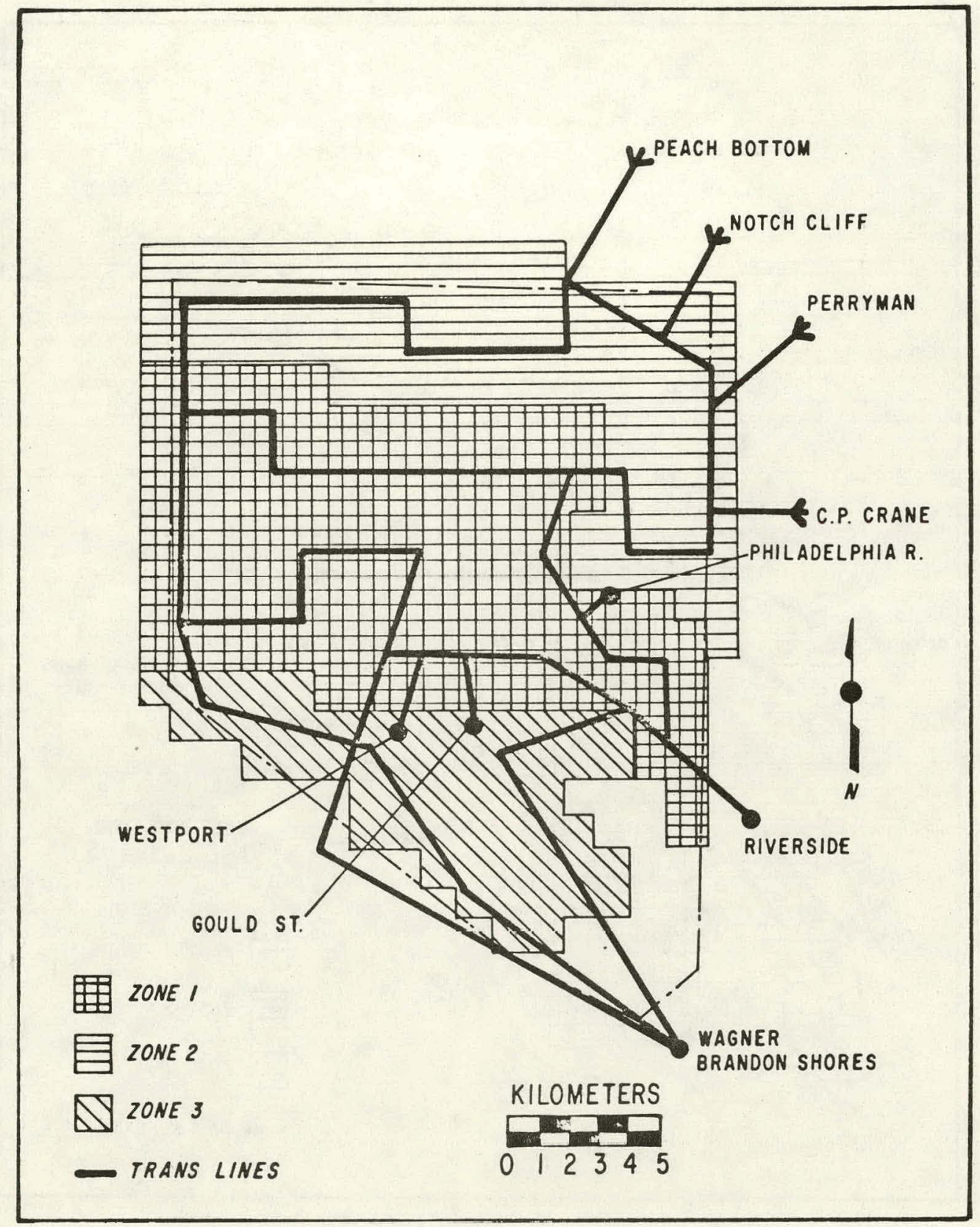

Fig. 4.19. Baltimore -- Demand Zones and Supply Lines 


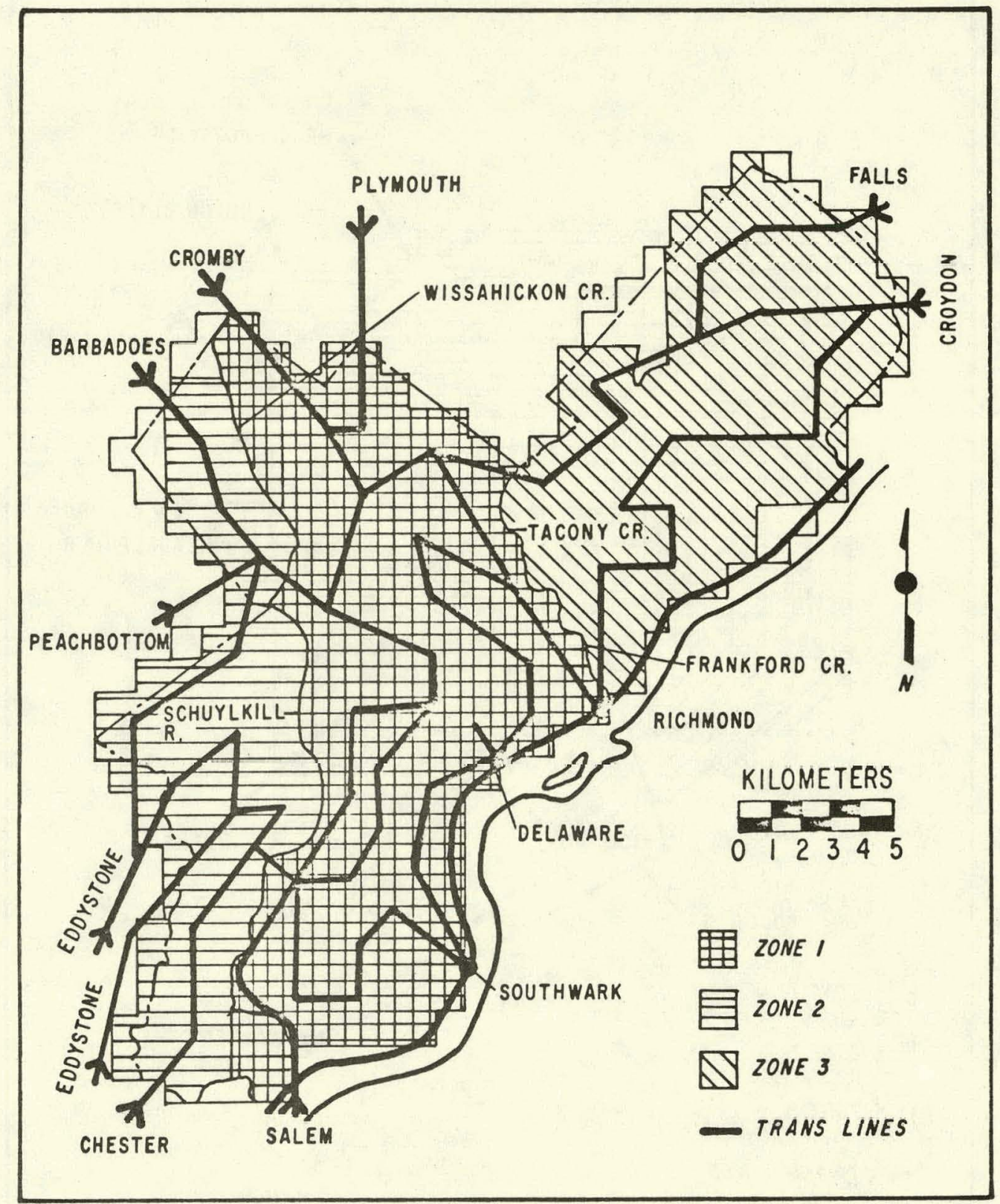

Fig. 4.20. Philadelphia -- Demand Zones and Supply Lines 
and projected. In all cases, a dual estimation methodology was utilized. The first estimate was high and used conservative costs. The second was less conservative and allowed for site-specific conditions as well as less expensive materials of construction. Another purpose of this study is to provide a range of costs. Much more detailed analysis will be needed to ascertain actual costs. The following cost components were analyzed:

Transmission Eiping: This item includes the costs of purchasing and installing pipe to connect supply points to demand sectors. Preliminary cost estimates for both initial capital and installation (urban and rural) were prepared by Burns \& Roe Corp. 14 High cost estimates utilized steel pipe and costs applicable to downtown and throughout the entire city. Low cost estimates substituted a synthetic pipe and a higher percentage of suburban/rural types of pipe installation.

Local Distribution Piping: This item is the connecting pipes from the transmission bus to the building wall. Detailed analysis of demand in certain northwestern cities was undertaken by the Energy Systems Research Group for Brookhaven National Laboratory. 2 That work was sufficient to allow the generation of cost/demand equations that were applied to the cities covered in this study. Once again high and low estimates were generated utilizing the same variables as for transmission piping.

End Use (BIdg.) Retrofit: In almost all cases, the end user will be required to retrofit this energy delivery system to utilize hot water as the principal energy source. Estimates on retrofit charges per square foot of building space were gleaned from previous work by Burns \& Roe. 14 Costs are available for various classifications of buildings. The dollar per square foot retrofit costs for high and low estimates were generated by using factors provided for differing classes of buildings. For example, the cost factor for apartment buildings of about 200 units was used city-wide for the high residential estimate $\left(\$ 0.32 / \mathrm{ft}^{2}\right)$ and the cost factor for apartment buildings of about 400 units was used for the low residential estimate $\left(\$ 0.24 / \mathrm{ft}^{2}\right)$.

Plant Retrofit: This item concerns the costs involved in preparing a supply facility to operate in a cogeneration mode. Any one of the five previously listed retrofit options was applied as the particular unit dictated. High cost estimates were conservative and involved costs at 15 percent of the current cost of the entire power plant, although costs would actually be confined to turbine modification. Costs of recuperative boilers and new thermal boilers were obtained from the literature.45,46 Because of the conservative approach given this item, low costs were simply taken as one-half the high costs. 
Replacement Capacity: This item includes: (1) the cost of constructing a new gas-turbine plant to replace the electrical generation lost because of retrofit; and (2) the cost of providing coal-based synthetic fuel to such new plants. This was determined to represent a lower cost than construction of coalfired power plants as replacement plants. 47,48

The need for such new capacity is obvious in that only a small amount of space heating in the study cities was provided by electric heat. Therefore, because the DES would substitute for scarce fuels but very little electricity, most of the electrical capacity lost as a result of retrofit would still be needed for its original uses.

Olle of the factors to be considered here, howcver, ia the time of ycar that peak electrical demands occur. Only if they occur simultaneously with peak thermal demand will lost electrical capacity have to be replaced. Currently, this does not occur because most utilities are summer peaking; whereas, the DES will have its peak demand in the winter. However, the DES is not a technology to be implemented in the present. If it is ever implemented on a large scale it will undoubtedly be the result of a gradual series of events (including this research) taking place over several years. The late 1980 s would be an early date for large-scale implementation. The ANL/ESCOR study group has projected, in an internal study, that most northern utilities will, in fact, be winter peaking by that time as a result of currently high rates of installation of electric heating. If this projection proves to be correct, then losses of electrical output to cogeneration will have to be replaced. Our cost estimates will then be correct in terms of including replacement capacity. If the projection does not prove to be true, then our cost estimates are ultra-conservative.

Even if the replacement capacity is necessary, we have not handled it in the least costly manner. Because the lost capacity would only be necessary to satisfy peak electrical demands, the appropriate choice of unit is the gas turbine. Assuming that gas turbine fuels become scarce, we have estimated fuel costs based on the assumption that coal liquefaction will provide the peaking fuel. What has been neglected at this point, is to make the replacement capacity itself cogenerating. Because gas turbines lose only $5-10 \%$ of their electrical capacity when cogenerating, this would be a logical way to expand the thermal, as well as electrical, capacity of the system. Preliminary analysis indicates that this could effectively bring costs down. Meanwhile, DES costs, estimated here, allow some fairly positive statements to be made about the potential of the technology.

Table 4.4 details the individual cost components by both zone and total city. Zone costs will vary widely as can be expected because of site-specific variations and because of some special-case situtations. For example, Zone II in Washington, D.C., shows a zero cost for electrical replacement capacity because the supply to that zone was provided by existing thermal boilers. Thus, no loss of electrical generation was incurred (i.e., through normal retrofit of existing generating units). 
Table 4.4. Capital Costs, City Zone (ANL/ESCOR Study Group Cities) (a)

\begin{tabular}{|c|c|c|c|c|c|c|c|c|c|c|c|c|c|}
\hline \multirow[b]{2}{*}{ City } & \multirow[b]{2}{*}{ Zone } & \multicolumn{6}{|c|}{ High Costs $\left(\$ \times 10^{6}\right)$} & \multicolumn{6}{|c|}{ Low Costs $\left(\$ \times 10^{6}\right)$} \\
\hline & & $\begin{array}{l}\text { Trans- } \\
\text { mission }\end{array}$ & $\begin{array}{l}\text { Distri- } \\
\text { bution }\end{array}$ & $\begin{array}{l}\text { Bldg. } \\
\text { Retrofit }\end{array}$ & $\begin{array}{l}\text { Plant } \\
\text { Retrofit }\end{array}$ & $\underset{\text { MW }}{\text { Replace }}$ & Total & $\begin{array}{l}\text { Trans- } \\
\text { mission }\end{array}$ & $\begin{array}{l}\text { Distri- } \\
\text { bution }\end{array}$ & $\begin{array}{l}\text { Bldg. } \\
\text { Retrofit }\end{array}$ & $\begin{array}{l}\text { Plant } \\
\text { Retrofit }\end{array}$ & $\underset{\text { MW }}{\text { Replace }}$ & Total \\
\hline $\begin{array}{l}\text { Washington } \\
\text { (ANL/ESCOR) }\end{array}$ & $\begin{array}{l}\text { I } \\
\text { II } \\
\text { II I } \\
\text { IV }\end{array}$ & $\begin{array}{r}115 \\
24 \\
161 \\
168\end{array}$ & $\begin{array}{r}287 \\
48 \\
218 \\
161\end{array}$ & $\begin{array}{r}136 \\
17 \\
47 \\
27\end{array}$ & $\begin{array}{r}72 \\
7 \\
31 \\
18\end{array}$ & $\begin{array}{r}234 \\
0 \\
144 \\
70\end{array}$ & $\begin{array}{r}844 \\
96 \\
601 \\
444\end{array}$ & $\begin{array}{r}47 \\
9 \\
83 \\
86\end{array}$ & $\begin{array}{r}100 \\
17 \\
76 \\
56\end{array}$ & $\begin{array}{l}82 \\
10 \\
31 \\
19\end{array}$ & $\begin{array}{r}36 \\
4 \\
16 \\
9\end{array}$ & $\begin{array}{r}107 \\
0 \\
72 \\
35\end{array}$ & $\begin{array}{r}372 \\
40 \\
278 \\
205\end{array}$ \\
\hline Total & & 468 & 714 & 227 & 128 & 448 & 1985 & 225 & 249 & 142 & 65 & 214 & 895 \\
\hline St. Louis & $\begin{array}{l}\text { I } \\
\text { II } \\
\text { III } \\
\text { IV }\end{array}$ & $\begin{array}{r}75 \\
93 \\
192 \\
90\end{array}$ & $\begin{array}{l}183 \\
180 \\
274 \\
167\end{array}$ & $\begin{array}{l}49 \\
37 \\
62 \\
34\end{array}$ & $\begin{array}{l}37 \\
26 \\
71 \\
31\end{array}$ & $\begin{array}{l}112 \\
122 \\
159 \\
134\end{array}$ & $\begin{array}{l}456 \\
458 \\
758 \\
456\end{array}$ & $\begin{array}{l}26 \\
47 \\
55 \\
58\end{array}$ & $\begin{array}{l}64 \\
63 \\
96 \\
59\end{array}$ & $\begin{array}{l}27 \\
21 \\
35 \\
30\end{array}$ & $\begin{array}{l}19 \\
13 \\
36 \\
16\end{array}$ & $\begin{array}{l}56 \\
61 \\
79 \\
67\end{array}$ & $\begin{array}{l}192 \\
205 \\
301 \\
230\end{array}$ \\
\hline Total & & 450 & 804 & 182 & 165 & 527 & 2128 & 186 & 282 & 113 & 84 & 263 & 928 \\
\hline Cleveland & $\begin{array}{l}\text { I } \\
\text { II } \\
\text { II I }\end{array}$ & $\begin{array}{r}157 \\
237 \\
74\end{array}$ & $\begin{array}{l}639- \\
380 \\
242\end{array}$ & $\begin{array}{r}129 \\
40 \\
28\end{array}$ & $\begin{array}{r}108 \\
48 \\
29\end{array}$ & $\begin{array}{l}453 \\
208 \\
110\end{array}$ & $\begin{array}{r}1486 \\
913 \\
483\end{array}$ & $\begin{array}{r}53 \\
111 \\
33\end{array}$ & $\begin{array}{r}221 \\
138 \\
85\end{array}$ & $\begin{array}{l}82 \\
27 \\
19\end{array}$ & $\begin{array}{l}54 \\
24 \\
15\end{array}$ & $\begin{array}{r}227 \\
104 \\
55\end{array}$ & $\begin{array}{l}637 \\
404 \\
207\end{array}$ \\
\hline Total & & 468 & 126.1 & 197 & 185 & 771 & 2882 & 197 & 444 & 128 & 93 & 386 & 1248 \\
\hline Milwaukee & $\begin{array}{l}\text { I } \\
\text { II } \\
\text { III }\end{array}$ & $\begin{array}{r}342 \\
212 \\
8\end{array}$ & $\begin{array}{l}501 \\
444 \\
308\end{array}$ & $\begin{array}{l}84 \\
56 \\
34\end{array}$ & $\begin{array}{r}76 \\
57 \\
133\end{array}$ & $\begin{array}{r}302 \\
291 \\
8\end{array}$ & $\begin{array}{r}1305 \\
1060 \\
491\end{array}$ & $\begin{array}{r}200 \\
57 \\
3\end{array}$ & $\begin{array}{l}174 \\
155 \\
108\end{array}$ & $\begin{array}{l}56 \\
34 \\
25\end{array}$ & $\begin{array}{l}38 \\
29 \\
67\end{array}$ & $\begin{array}{r}151 \\
146 \\
4\end{array}$ & $\begin{array}{l}619 \\
421 \\
207\end{array}$ \\
\hline Total & & 562 & .1253 & 174 & 266 & 601 & 2856 & 260 & 437 & 115 & 134 & 301 & 1247 \\
\hline Detroit & $\begin{array}{l}\text { I } \\
\text { II } \\
\text { III }\end{array}$ & $\begin{array}{l}517 \\
133 \\
209 .\end{array}$ & $\begin{array}{l}827 \\
446 \\
940\end{array}$ & $\begin{array}{r}133 \\
63 \\
73\end{array}$ & $\begin{array}{r}104 \\
84 \\
67\end{array}$ & $\begin{array}{l}448 \\
300 \\
264\end{array}$ & $\begin{array}{l}2029 \\
1026 \\
1553\end{array}$ & $\begin{array}{r}299 \\
47 \\
110\end{array}$ & $\begin{array}{l}299 \\
156 \\
329\end{array}$ & $\begin{array}{l}88 \\
43 \\
47\end{array}$ & $\begin{array}{l}52 \\
42 \\
34\end{array}$ & $\begin{array}{l}224 \\
150 \\
132\end{array}$ & $\begin{array}{l}962 \\
438 \\
652\end{array}$ \\
\hline Total & & 859 & 2213 & 269 & 255 & 1012 & 4608 & 456 & 784 & 178 & 128 & 506 & 2052 \\
\hline Chicago & $\begin{array}{l}\text { I } \\
\text { IIII }\end{array}$ & $\begin{array}{l}273 \\
291 \\
378\end{array}$ & $\begin{array}{l}120 \\
596 \\
576\end{array}$ & $\begin{array}{l}259 \\
177 \\
161\end{array}$ & $\begin{array}{r}59 \\
102 \\
108\end{array}$ & $\begin{array}{c}267 \\
392 \\
613\end{array}$ & $\begin{array}{r}978 \\
1558 \\
1836\end{array}$ & $\begin{array}{r}96 \\
204 \\
188\end{array}$ & $\begin{array}{r}42 \\
209 \\
202\end{array}$ & $\begin{array}{l}140 \\
110 \\
108\end{array}$ & $\begin{array}{l}30 \\
51 \\
54\end{array}$ & $\begin{array}{l}134 \\
196 \\
307\end{array}$ & $\begin{array}{l}442 \\
770 \\
859\end{array}$ \\
\hline Total & & 942 & 1292 & 597 & 269 & 1272 & 4372 & 488 & 453 & 358 & 135 & 637 & 2071 \\
\hline
\end{tabular}




\subsection{ANNUALIZED SYSTEM COSTS}

Annual costs are composed of four components as follows:

(1) operation and maintenance (O\&M) charges for piping systems;

(2) operation and maintenance charges for portions of plant associated with cogeneration;

(3) fuel costs associated with cogeneration, including pumping requirements; and

(4) capital recovery charges.

O\&M costs for piping systews are derived from the Net Energy Methodology developed for DOE (then ERDA). 47 The factors chosen here were based on an analogy to charges that have been experienced by owner/operators of major pipeline systems, including oil, gas, and coal-slurry transmission or distribution lines. To be consistent with our high-low estimates, factors were chosen at both extremes of the reported values. These O\&M factors are simply a ratio of dollars expended for annual O\&M to initial capital dollars invested, i.e., a simple multiplication of the O\&M factor times the sum of capital cost for transmission and local distribution gives us the desired dollar value. O\&M for end use retrofit, i.e., the retrofit of systems in buildings, was not considered a proper DES charge. This cost traditionally is borne by the end user, so this report follows that tradition.

To assess properly the O\&M charges attributable to DES plant operation, a general concept must be found as to how often a specific plant (or unit) will operate. In this study, it is assumed that the relative order of plant loading before DES operation will remain after retrofit. Thus, base-load plants would operate first, followed by intermediate plants, followed by peakers. Within these categories, coal and nuclear-fired plants are operated before oil- or gas-fired plants. A relative ranking by heat available and load factors allows an estimate of the percentage of time a unit must operate to meet overall zone demand. From this analysis, it is simple to determine the amount of electricity that a selected unit would produce during the period of cogeneration, had the cogeneration mode been inoperative. Cogeneration is assumed to double the normal O\&M costs of the unit during the period of cogeneration. When the normal electrical output during this period is known, the Net Energy Method again provides O\&M costs for the various types of electric generating facilities. These factors are related in terms of $\$ / B t u$ produced by the plant to arrive at an estimate of O\&M cost caused by cogeneration.

Fuel costs obviously are highly dependent on the type of fuel used. Escalated FEA cost estimates adjusted to 1977 for the geographic areas under investigation were utilized in this study. 49 The only exception to this rule is the Chicago-area Commonwealth Edison data which were used as a basis for nuclear fuel costs. Total fuel costs (TFC) are calculated according to the following formula:

$\mathrm{TFC}=\mathrm{Btu} / \mathrm{yr}$ thermal capacity of the plant $\mathrm{x}$ plant thermal use factor $x$ plant heat unit fuel cost. 
Table 4.5 displays the individual and composite annual costs by zone and by city. As was the case in Table 4.4, there is wide variation among zones because of site-specific criteria. For example, in Zone II, Cleveland shows a fuel cost of only $\$ 1.39 \times 10^{6} \mathrm{Btu} / \mathrm{yr}$. This is because the only plant in that zone is nuclear powered and thus has a.low fuel charge.

Capital recovery costs depend on interest rates and payback time. In this study, two payback scenarios are assessed for both high and low costs. The first scenario projects interest rates of $8 \%$ and a project 1 ife of 20 yrs; the second projects interest rates of $20 \%$ and a project life of 20 yrs. From all of the above, total annual costs (TAC) can be derived in $\$ / 10^{6}$ Btu from the following formula:

$$
\mathrm{TAC}=\frac{\text { Capital Costs } \times \text { Capital Recovery Factor }+ \text { O\&M Costs }+ \text { Fuel Costs }}{\text { Annual Btu Demand per Zone } \times 10^{6}}
$$

Table 4.6 shows the results of such calculations. This calculation places all zones on a standard basis to allow an accurate assessment of the estimated costs of a DES. The slight variability within zones is to be. expected because of site-specific considerations. However, the most striking aspect of Table 4.6 is the close correlation between overall costs per $10^{6}$ Btu among the various cities. 
Table 4.5. DES -- Operation \& Maintenance Costs (1977\$)

\begin{tabular}{|c|c|c|c|c|c|c|c|c|c|}
\hline \multirow[b]{2}{*}{ City } & \multirow[b]{2}{*}{ Zone } & \multicolumn{4}{|c|}{ High Estimate $\left(\$ \times 10^{6}\right) / y r$} & \multicolumn{4}{|c|}{ Low Estimate $\left(\$ \times 10^{6}\right) / y r$} \\
\hline & & $\begin{array}{r}\text { Trans. } \\
\text { Dist. }\end{array}$ & $\begin{array}{l}\text { Plant } \\
\text { O\&M }\end{array}$ & $\begin{array}{r}\text { Fue 1 } \\
\text { Costs }\end{array}$ & Total & $\begin{array}{c}\text { Trans. } \\
\text { Dist. }\end{array}$ & $\begin{array}{l}\text { Plant } \\
\text { O\&M }\end{array}$ & $\begin{array}{r}\text { Fuel } \\
\text { Costs }\end{array}$ & Total \\
\hline $\begin{array}{l}\text { Washingt on } \\
\text { (ANL/ESCOR) }\end{array}$ & $\begin{array}{l}\text { I } \\
\text { II } \\
\text { II I } \\
\text { IV }\end{array}$ & $\begin{array}{r}16.3 \\
2.9 \\
15.4 \\
13.4\end{array}$ & $\begin{array}{l}9.9 \\
0.46 \\
5.64 \\
2.02\end{array}$ & $\begin{array}{r}17.90 \\
3.11 \\
6.13 \\
2.69\end{array}$ & $\begin{array}{r}44.10 \\
6.47 \\
27.17 \\
18.11\end{array}$ & $\begin{array}{l}0.98 \\
0.17 \\
1.07 \\
0.95\end{array}$ & $\begin{array}{l}4.95 \\
0.23 \\
2.82 \\
1.01\end{array}$ & $\begin{array}{r}17.90 \\
3.11 \\
6.13 \\
2.69\end{array}$ & $\begin{array}{r}28.53 \\
3.51 \\
10.02 \\
4.65\end{array}$ \\
\hline Total & & 48.0 & 18.02 & 29.83 & 95.85 & 3.17 & 9.01 & 29.83 & 42.01 \\
\hline St. Louis & $\begin{array}{l}I \\
I I \\
I I I \\
I V\end{array}$ & $\begin{array}{l}10.48 \\
11.09 \\
18.92 \\
10.43\end{array}$ & $\begin{array}{l}3.15 \\
4.54 \\
7.10 \\
5.07\end{array}$ & $\begin{array}{r}12.21 \\
4.08 \\
7.78 \\
5.92\end{array}$ & $\begin{array}{l}25.84 \\
19.71 \\
33.8 \\
21.42\end{array}$ & $\begin{array}{l}0.60 \\
0.74 \\
1.01 \\
0.78\end{array}$ & $\begin{array}{l}1.58 \\
2.27 \\
3.55 \\
? .54\end{array}$ & $\begin{array}{r}12.21 \\
4.08 \\
7.78 \\
5.92\end{array}$ & $\begin{array}{r}14.39 \\
7.09 \\
12.34 \\
9.24\end{array}$ \\
\hline Total & & 50.92 & 19.86 & 39.09 & 300,77 & 3.13 & 2.94 & 29.99 & 43.06 \\
\hline Cleveland & $\begin{array}{l}\text { I } \\
\text { II } \\
\text { II I }\end{array}$ & $\begin{array}{l}32.32 \\
25.06 \\
12.83\end{array}$ & $\begin{array}{r}18.05 \\
6.89 \\
7.49\end{array}$ & $\begin{array}{r}20.14 \\
8.02 \\
1.39\end{array}$ & $\begin{array}{l}70.51 \\
39.97 \\
21.71\end{array}$ & $\begin{array}{l}1.85 \\
1.63 \\
0.79\end{array}$ & $\begin{array}{l}9.03 \\
3.45 \\
3.74\end{array}$ & $\begin{array}{r}20.14 \\
8.02 \\
1.39\end{array}$ & $\begin{array}{r}31.02 \\
13.10 \\
5.92\end{array}$ \\
\hline Total & & 70.21 & 32.43 & 29.55 & 132.19 & 4.27 & 16.22 & 29.55 & 50.04 \\
\hline Milwaukee & $\begin{array}{l}\text { I } \\
\text { II } \\
\text { III }\end{array}$ & $\begin{array}{l}34.23 \\
26.64 \\
12.83\end{array}$ & $\begin{array}{r}16.30 \\
10.59 \\
3.50\end{array}$ & $\begin{array}{r}10.93 \\
8.71 \\
17.40\end{array}$ & $\begin{array}{l}61.46 \\
45.94 \\
33.73\end{array}$ & $\begin{array}{l}2.50 \\
1.42 \\
0.74\end{array}$ & $\begin{array}{l}8.15 \\
5.30 \\
1.75\end{array}$ & $\begin{array}{r}10.93 \\
8.71 \\
17.40\end{array}$ & $\begin{array}{l}21.58 \\
15.43 \\
19.89\end{array}$ \\
\hline Total & & 73.70 & 30.39 & 37.04 & 141.13 & 4.66 & 15.20 & 37.04 & 56.90 \\
\hline Detroit & $\begin{array}{l}\text { I } \\
\text { II } \\
\text { III. }\end{array}$ & $\begin{array}{l}54.58 \\
23.51 \\
46.66\end{array}$ & $\begin{array}{l}29.08 \\
12.77 \\
12.90\end{array}$ & $\begin{array}{l}25.39 \\
29.32 \\
12.16\end{array}$ & $\begin{array}{r}109.05 \\
65.60 \\
71.72\end{array}$ & $\begin{array}{l}4.00 \\
1.36 \\
2.94\end{array}$ & $\begin{array}{r}14.51 \\
6.38 \\
6.45\end{array}$ & $\begin{array}{l}25.39 \\
29.32 \\
12.16\end{array}$ & $\begin{array}{l}43.90 \\
37.06 \\
21.55\end{array}$ \\
\hline Total & & 124.75 & 54.75 & 66.87 & 246.37 & 8.30 & 27.34 & 66.87 & 102.51 \\
\hline Chicago & $\begin{array}{l}\text { I } \\
\text { II } \\
\text { III }\end{array}$ & $\begin{array}{l}15.96 \\
56.02 \\
20.74\end{array}$ & $\begin{array}{r}5.73 \\
21.33 \\
48.22\end{array}$ & $\begin{array}{r}8.05 \\
26.07 \\
15.01\end{array}$ & $\begin{array}{c}29.7 \\
103.42 \\
83.97\end{array}$ & $\begin{array}{l}0.92 \\
2.76 \\
2.61\end{array}$ & $\begin{array}{r}2.87 \\
10.67 \\
24.11\end{array}$ & $\begin{array}{r}8.05 \\
26.07 \\
15.01\end{array}$ & $\begin{array}{l}11.84 \\
39.50 \\
41.73\end{array}$ \\
\hline Total & & 92.72 & 75.28 & 49.13 & 217.13 & 6.29 & 37.65 & 49.13 & 93.07 \\
\hline Philadelphia & $\begin{array}{l}\text { I } \\
\text { II } \\
\text { III }\end{array}$ & $\begin{array}{l}75.74 \\
45.81 \\
35.82\end{array}$ & $\begin{array}{r}30.23 \\
16.16 \\
.6 .66\end{array}$ & $\begin{array}{l}60.37 \\
12.33 \\
12.64\end{array}$ & $\begin{array}{r}166.34 \\
74.30 \\
55.12\end{array}$ & $\begin{array}{l}4.97 \\
8.90 \\
2.33\end{array}$ & $\begin{array}{r}15.12 \\
8.08 \\
3.33\end{array}$ & $\begin{array}{l}60.37 \\
12.33 \\
12.64\end{array}$ & $\begin{array}{l}80.46 \\
24.31 \\
18.30\end{array}$ \\
\hline Total & & 157.37 & 53.05 & 85.34 & 295.76 & 11.20 & 26.53 & 85.34 & 123.07 \\
\hline $\begin{array}{l}\text { Washington } \\
\text { (BNL/ESRG) }\end{array}$ & $\begin{array}{l}\text { I } \\
\text { II } \\
\text { III }\end{array}$ & $\begin{array}{l}20.55 \\
21.40 \\
15.63\end{array}$ & $\begin{array}{l}9.55 \\
6.09 \\
2.94\end{array}$ & $\begin{array}{r}18.98 \\
5.87 \\
3.30\end{array}$ & $\begin{array}{l}49.08 \\
33.36 \\
21.87\end{array}$ & $\begin{array}{l}1.30 \\
1.62 \\
1.11\end{array}$ & $\begin{array}{l}4.78 \\
3.05 \\
1.46\end{array}$ & $\begin{array}{r}18.98 \\
5.87 \\
3.30\end{array}$ & $\begin{array}{r}25.06 \\
-10.54 \\
5.87\end{array}$ \\
\hline Total & & 57.58 & 18.58 & 28.15 & 104.31 & 4.03 & 9.29 & 28.15 & 41.47 \\
\hline Boston & $\begin{array}{l}\text { I } \\
\text { II }\end{array}$ & $\begin{array}{l}27.17 \\
39.39\end{array}$ & $\begin{array}{l}14.17 \\
12.76\end{array}$ & $\begin{array}{r}33.90 \\
9.12\end{array}$ & $\begin{array}{l}75.24 \\
61.27\end{array}$ & $\begin{array}{l}1.79 \\
3.22\end{array}$ & $\begin{array}{l}7.09 \\
6.37\end{array}$ & $\begin{array}{r}33.90 \\
9.12\end{array}$ & $\begin{array}{l}42.78 \\
18.71\end{array}$ \\
\hline Total & & 66.56 & 26.93 & 43.02 & 136.51 & 5.01 & 13.46 & 43.02 & 61.49 \\
\hline Baltimore & $\begin{array}{l}\text { I } \\
\text { II } \\
\text { III }\end{array}$ & $\begin{array}{l}53.24 \\
29.60 \\
12.30\end{array}$ & $\begin{array}{r}19.78 \\
8.17 \\
3.06\end{array}$ & $\begin{array}{r}34.45 \\
6.31 \\
5.02\end{array}$ & $\begin{array}{r}107.47 \\
44.08 \\
20.38\end{array}$ & $\begin{array}{l}3.64 \\
2.30 \\
0.77\end{array}$ & $\begin{array}{r}9.89 \\
4.09 \\
1.53\end{array}$ & $\begin{array}{r}34.45 \\
6.31 \\
5.02\end{array}$ & $\begin{array}{r}47.98 \\
12.70 \\
7.32\end{array}$ \\
\hline Total & & 95.14 & 31.01 & 45.78 & $171.93^{\circ}$ & 6.71 & 15.51 & 45.78 & 68.00 \\
\hline
\end{tabular}


Table 4.6. Cost per $10^{6}$ Btu at 20 Yr Equipment Lifetimes and $8 \%$ or $20 \%$ Interest Rates $\left(\$ / 10^{6}\right.$. Btu)

\begin{tabular}{|c|c|c|c|c|c|}
\hline \multirow[b]{2}{*}{ City } & \multirow[b]{2}{*}{ Zone } & \multicolumn{2}{|c|}{ At $8 \%-20$ yrs. } & \multicolumn{2}{|c|}{ At $20 \%-20$ yrs. } \\
\hline & & High & Low & High & Low \\
\hline $\begin{array}{l}\text { Washingt on } \\
\text { (ANL/ESCOR) }\end{array}$ & $\begin{array}{l}\text { I } \\
\text { II } \\
\text { III } \\
\text { IV }\end{array}$ & $\begin{array}{r}9.71 \\
9.98 \\
14.03 \\
13.89\end{array}$ & $\begin{array}{l}4.61 \\
4.66 \\
6.09 \\
5.60\end{array}$ & $\begin{array}{r}16.23 \\
16.08 \\
23.91 \\
23.97\end{array}$ & $\begin{array}{r}7.83 \\
7.20 \\
10.66 \\
10.25\end{array}$ \\
\hline Total City & . & 11.52 & 5.15 & 19.46 & 8.73 \\
\hline St. Louis & $\begin{array}{l}\text { I } \\
\text { II } \\
\text { III } \\
\text { IV }\end{array}$ & $\begin{array}{l}12.41 \\
12.77 \\
13.33 \\
13.10\end{array}$ & $\begin{array}{l}5.83 \\
5.38 \\
5.16 \\
6.30\end{array}$ & $\begin{array}{l}20.52 \\
21.90 \\
22.75 \\
22.21\end{array}$ & $\begin{array}{r}9.24 \\
9.47 \\
8.91 \\
10.90\end{array}$ \\
\hline Total City & & 12.95 & 5.61 & 21.93 & 9.53 \\
\hline Clevel and & $\begin{array}{l}\text { I } \\
\text { I I } \\
\text { I I I }\end{array}$ & $\begin{array}{l}10.34 \\
15.29 \\
10.77\end{array}$ & $\begin{array}{l}4.47 \\
6.24 \\
4.10\end{array}$ & $\begin{array}{l}17.52 \\
26.15 \\
18.37\end{array}$ & $\begin{array}{r}7.55 \\
11.05 \\
7.36\end{array}$ \\
\hline Total City & & 11.59 & 4.82 & 19.71 & 8.34 \\
\hline Milwaukee & $\begin{array}{l}\text { I } \\
\text { II } \\
\text { II I }\end{array}$ & $\begin{array}{r}11.41 \\
11.85 \\
8.87\end{array}$ & $\begin{array}{l}4.97 \\
4.49 \\
4.34\end{array}$ & $\begin{array}{l}19.33 \\
20.30 \\
14.25\end{array}$ & $\begin{array}{l}8.73 \\
7.85 \\
6.61\end{array}$ \\
\hline Total City & & 10.95 & 4.66 & 18.43 & 7.93 \\
\hline Detroit & $\begin{array}{l}\text { I } \\
\text { II } \\
\text { III }\end{array}$ & $\begin{array}{l}11.37 \\
11.54 \\
15.95\end{array}$ & $\begin{array}{l}5.11 \\
5.54 \\
6.10\end{array}$ & $\begin{array}{l}18.93 \\
18.74 \\
27.11\end{array}$ & $\begin{array}{r}8.69 \\
8.62 \\
10.79\end{array}$ \\
\hline Total City & & 12.57 & 5.47 & 20.95 & 9.20 \\
\hline Chicago & $\begin{array}{l}\text { I } \\
\text { II } \\
\text { III }\end{array}$ & $\begin{array}{r}17.82 \\
9.88 \\
8.60\end{array}$ & $\begin{array}{l}7.83 \\
4.45 \\
4.10\end{array}$ & $\begin{array}{l}31.77 \\
15.96 \\
14.63\end{array}$ & $\begin{array}{r}14.14 \\
7.45 \\
6.92\end{array}$ \\
\hline Total City & & 10.14 & 4.66 & 17.08 & 7.94 \\
\hline $\begin{array}{l}\text { Washingt on } \\
\text { (BNL/ESRG) }\end{array}$ & $\begin{array}{l}\text { I } \\
\text { II } \\
\text { III }\end{array}$ & $\begin{array}{r}8.44 \\
15.44 \\
12.18\end{array}$ & $\begin{array}{l}4.04 \\
6.79 \\
4.99\end{array}$ & $\begin{array}{l}14.20 \\
26.64 \\
20.87\end{array}$ & $\begin{array}{r}6.72 \\
12.28 \\
9.06\end{array}$ \\
\hline Total City & & 10.85 & 4.89 & 18.48 & 8.51 \\
\hline Boston & $\begin{array}{l}\text { T } \\
\text { II }\end{array}$ & $\begin{array}{r}9.55 \\
16.70\end{array}$ & $\begin{array}{l}4.81 \\
7.52\end{array}$ & $\begin{array}{l}15.64 \\
28.77\end{array}$ & $\begin{array}{r}7.64 \\
13.67\end{array}$ \\
\hline Total City & & 12.24 & 5.83 & 20.57 & 9.91 \\
\hline Baltimore & $\begin{array}{l}\text { I } \\
\text { II } \\
\text { III }\end{array}$ & $\begin{array}{l}10.42 \\
17.74 \\
18.16\end{array}$ & $\begin{array}{l}4.78 \\
8.24 \\
7.39\end{array}$ & $\begin{array}{l}17.33 \\
30.36 \\
30.92\end{array}$ & $\begin{array}{r}7.99 \\
13.89 \\
12.86\end{array}$ \\
\hline Total City & & 12.55 & 5.58 & 21.11 & 9.59 \\
\hline Philadel phi, & $\begin{array}{l}\text { I } \\
\text { II } \\
\text { III }\end{array}$ & $\begin{array}{r}9.59 \\
15.52 \\
13.28\end{array}$ & $\begin{array}{l}4.48 \\
7.19 \\
5.31\end{array}$ & $\begin{array}{l}15.83 \\
26.60 \\
22.34\end{array}$ & $\begin{array}{r}7.35 \\
12.96 \\
9.33\end{array}$ \\
\hline Total City & . & 11.43 & 5.18 & 19.14 & 8.83 \\
\hline
\end{tabular}


THIS PAGE

\section{WAS INTENTIONALLY \\ LEFT BLANK}




\subsection{ALTERNATIVE SYSTEMS}

Having arrived at overall annual costs involved in a DES, a consideration is made of alternative energy delivery systems that could be used instead of DES. In each analysis, the basic premise is that an energy delivery system must be built so that it can provide enough energy to meet the demands that were used in the DES analysis.

Three alternate energy systems were analyzed:

(1) coal-to-electricity-to-heat;

(2) coal-to-gas via gasification-to-heat;

(3) coal-to-oil via liquefaction-to-heat.

In each case, an amended net energy methodology was used as the starting point for cost calculations. The procedure selected in arriving at final costs was similar to that used in the DES option. Thus, capital costs, O\&M costs, fuel costs, and capital recovery costs were established and utilized to arrive at final $\$ / 10^{6}$ Btu estimates.47-49 Results of these calculations are shown in Tables 5.1-5.3.

Table 5.1. Costs of Coal-Electric Option (Total City)

\begin{tabular}{|c|c|c|c|c|c|c|}
\hline City & $\begin{array}{l}\text { Plant } \\
\text { Supply } \\
(M W)\end{array}$ & $\begin{array}{c}\text { Capital } \\
\text { Costs } \\
\left(\$ \times 10^{6}\right)\end{array}$ & $\begin{array}{l}\text { Total } \\
\text { Annual } \\
\text { Costs } \\
\left(\begin{array}{c}\text { S } 10^{6} \\
/ \text { Yr })\end{array}\right.\end{array}$ & $\begin{array}{c}\text { Fuels } \\
\text { Costs } \\
(\$ \mathrm{x} \\
10^{6 \mathrm{Btu})}\end{array}$ & $\begin{array}{c}8 \%-20 \mathrm{Yr} \\
(\$ \mathrm{x} \\
\left.10^{6} \mathrm{Btu}\right)\end{array}$ & $\begin{array}{r}20 \%-20 \mathrm{Yr} \\
(\$ \mathrm{x} \\
\left.10^{6} \mathrm{Btu}\right)\end{array}$ \\
\hline $\begin{array}{l}\text { Washington } \\
\text { (ANL/ESCOR) }\end{array}$ & 5,116 & 4,101 & .58 .43 & 40.32 & 19.96 & 36.36 \\
\hline St. Louis & 4,975 & 3,988 & 56.83 & 31.02 & 20.14 & 36.97 \\
\hline Clevel and & 5,995 & 4,806 & 68.49 & 46.45 & 16.46 & 30.00 \\
\hline Milwaukee & 6,270 & 5,026 & 71.62 & 49.92 & 16.05 & 29.23 \\
\hline Detroit & 8,592 & 6,888 & 98.15 & 72.00 & 15.31 & 27.84 \\
\hline Chicago & 13,300 & 10,662 & 151.93 & 82.59 & 20.22 & 37.12 \\
\hline $\begin{array}{l}\text { Washington } \\
\text { (BNL/ESRG) }\end{array}$ & 5,447 & 4,366 & 62.22 & 48.76 & 17.75 & 32.19 \\
\hline Boston & 5,368 & 4,303 & $61: 32$ & 52.61 & 16.35 & 29.87 \\
\hline Balt imore & 6,641 & 5,324 & 75.87 & 64.89 & 16.40 & 29.63 \\
\hline Phillade 1.phia & 11,928 & 9,561 & 136.24 & 119.96 & 15.98 & 28.83 \\
\hline
\end{tabular}


Table 5.2. Costs of Coal Gasification Option (Total City)

\begin{tabular}{|c|c|c|c|c|c|c|}
\hline City & $\begin{array}{c}\text { Btu } \\
\text { Demand } \\
(\text { Btu/Yr } \\
\left.\times 10^{9}\right)\end{array}$ & $\begin{array}{c}\text { Capital } \\
\text { Costs } \\
\left(\$ \times 10^{6}\right)\end{array}$ & $\begin{array}{c}\text { Total } \\
\text { Annual } \\
\text { Costs } \\
\left(\$ \times 10^{6}\right)\end{array}$ & $\begin{array}{c}\text { Fuel } \\
\text { Costs } \\
(\$ x \\
\left.10^{6} \mathrm{Btu}\right)\end{array}$ & $\begin{array}{c}8 \%-20 \mathrm{Yr} \\
(\$ \mathrm{x} \\
10^{6 \mathrm{Btu})}(\mathrm{a})\end{array}$ & $\begin{array}{c}20 \%-20 \mathrm{Yr} \\
(\$ \times \\
\left.\$ \times 10^{6}\right)\end{array}$ \\
\hline \multicolumn{7}{|l|}{ Washingt on } \\
\hline (ANL/ESCOR) & 25,879 & 607.2 & 19.43 & 80.64 & 6.26 & 8.69 \\
\hline St. Louis & 24,526 & 575.5 & 18.42 & 62.04 & 5.67 & 8.10 \\
\hline Clevel and & 36,726 & 861.7 & 27.57 & 92.91 & 5.67 & 8.10 \\
\hline Mi 1waukee & 39,463 & 925.9 & 29.63 & 99.83 & 5.67 & 8.10 \\
\hline Detroit & 56,923 & 1336.0 & 42.75 & 144.00 & 5.67 & 8.10 \\
\hline Chicago & 65,298 & 1532.0 & 49.02 & 165.19 & 5.67 & 8.10 \\
\hline \multicolumn{7}{|l|}{ Washingt on } \\
\hline (BNL/ESRG) & 31,300 & 734.4 & 23.50 & 97.54 & 6.26 & 8.69 \\
\hline Boston & 33,768 & 792.3 & 25.35 & 105.23 & 6.26 & 8.69 \\
\hline Baltimore & 41,648 & 977.2 & 31.27 & 129.78 & 6.26 & 8.69 \\
\hline Philadelphia & 76,990 & 1806.0 & 57.79. & 239.91 & 6.26 & 8.69 \\
\hline \multicolumn{7}{|c|}{$\begin{array}{l}\text { (a) Since no transmission/distribution costs are assumed, there is no urban } \\
\text { area specific variation in these costs. Capital costs per Btu for the } \\
\text { plant are assumed constant. Only fuel charges are varied by region. } \\
\text { Thus the uniform cost values result. More detailed analysis would un- } \\
\text { doubtedly show substantial variation among the cities. }\end{array}$} \\
\hline \multicolumn{7}{|c|}{ Table 5.3. Costs -- Coal Liquids Option (Total City) } \\
\hline City & $\begin{array}{c}\text { Btu } \\
\text { Demand } \\
(B t u / Y r \\
\left.x 10^{9}\right)\end{array}$ & $\begin{array}{c}\text { Capital } \\
\text { Costs } \\
\left(\$ \times 10^{6}\right)\end{array}$ & $\begin{array}{c}\text { Total } \\
\text { Annual } \\
\text { Costs } \\
\left(\$ \times 10^{6}\right)\end{array}$ & $\begin{array}{c}\text { Fue } 1 \\
\text { Costs } \\
(\$ \mathrm{x} \\
\left.10^{6 \mathrm{Btu}}\right)\end{array}$ & $\begin{array}{c}8 \%-20 \mathrm{Yr} \\
(\$ \mathrm{x} \\
\left.10^{6} \mathrm{Btu}\right)(\mathrm{a})\end{array}$ & $\begin{array}{r}20 \%-20 \mathrm{Yr} \\
(\$ \mathrm{x} \\
\left.10^{6} \mathrm{Bt} \cdot \mathrm{u}\right)\end{array}$ \\
\hline \multicolumn{7}{|l|}{ Washíngton } \\
\hline (ANL/ESCOR) & 25,879 & 687.2 & 32.56 & 65.90 & 6.51 & 9.26 \\
\hline St. Louis & 24,526 & 651.2 & 30.85 & 50.70 & 6.03 & 8.78 \\
\hline Clevel and & 36,726 & 975.2 & 46.20 & 75.92 & 6.03 & 8.78 \\
\hline Mi 1waukee & 39,463 & 1048.0 & 49.65 & 81.58 & 6.03 & 8.78 \\
\hline Detroit & 56,923 & 1511.0 & 71.59 & 117.67 & 6.03 & $8.78^{\circ}$ \\
\hline Chicago & 65,298 & 1734.0 & 82.16 & 134.98 & 6.03 & 8.78 \\
\hline \multicolumn{7}{|l|}{ Washingt on } \\
\hline (BNL/ESRG) & 31,300 & 831.1 & 39.38 & 79.70 & 6.51 & 9.26 \\
\hline Boston & 33,768 & 896.6 & 42.48 & 85.98 & 6.51 & 9.26 \\
\hline Baltimore & 41,648 & 1106.0 & 52.40 & 106.05 & $6: 51$ & 9.26 \\
\hline Philadelphia & 76,990 & 2044.0 & 96.84 & 196.04 & 6.51 & 9.26 \\
\hline
\end{tabular}

$(a)$ See note to Table 5.2 . 


\subsubsection{Coal-to-Electricity-to-Heat}

The overall net energy trajectory 47 for this option assumed a $65 \%$ power plant capacity figure, a $34 \%$ power plant efficiency, and a 20-yr lifecycle for all major components. Three adjustments have been made to the net energy methodology to make it more consistent with the work undertaken in this study:

(1) Power plant costs are escalated from $\$ 445 \times 10^{6} / 1000 \mathrm{MW}$ to $\$ 635 \times 10^{6} / 1000$ MW to reflect recent cost estimates. 48

(2) The overall plant capacity utilization (based on load curve analysis) for space heating is approximately .325 which is one-half the original $65 \%$ estimate. Although this causes a high electrical cost estimate, it reflects actual costs associated with constructing a winter peaking plant specifically for space heating.*

(3) The overall plant efficiency (based on new unit designs) is estimated at $42 \%$ rather than at $34 \%$ as originally estimated. Such corrections were incorporated.

After correction, the following capital costs 47 for the trajectory components were:

$\begin{array}{llr} & & \frac{\$ / 10^{9} \mathrm{Btu}}{} \\ \text { Underground Mine } & = & 3,120 \\ \text { Cleaning Plant } & = & 400 \\ \text { Rail Transport } & = & 1,400 \\ \text { Power Plant } & = & 74,440 \\ \text { Transmission } & = & 12,920 \\ \text { Distribution } & = & 25,200 \\ \text { Total } & = & 117,480\end{array}$

Using the above figure, the ratio of total pathway costs to power plant cost is $\$ 117,480 / 74,440=1.58$. This ratio is used as the pathway capital multiplier.

The pathway multiplier can be utilized on the amount of electric capacity needed to replace the DES capacity. Although the electric system is charged for fuel on the basis of heat-pump efficiency, it is sized on the basis of resistance heat backup to the heat pump. Thus, because of the differences in end-use efficiency of hot water systems (some $80 \%$ ) and electric resistance heating (some $100 \%$ ), the total capacity required in the electric option is $80 \%$ of that required by the DES system. Thus, the overall formula to arrive at total electric option capital costs is:

* See Ref. 1 for additional discussion of this issue. The 0.325 plant capacity utilization is, if anything, high in the context of the heating service area assumptions made in this report. Lowering the utilization factor would not alter the basic findings of this report. 
Capital Costs $=$ MW of DES $\times 0.8 \times$ Cost $/$ MW $\times$ Pathway Multiplier

or, for St. Louis:

$$
\text { Capital Costs }=4975(0.8)\left(.635 \times 10^{6}\right)(1.578)=\$ 3989 \times 10^{6}
$$

No costs are included for end-use retrofit; this lowers the cost estimates of this option substantially relative to their other options. However, this omission does not affect the relative economic ranking of the alternatives evaluated here.

Operation and maintenance costs are projected on the basis of the amended net energy procedure, as a muliplier of capital costs. For coal-electric heat: 47

$$
\text { O\&M Multiplier }=\frac{\text { Total O\&M Costs }}{\text { Total Capital Costs }}=\frac{1,674}{117,480}=0.01425
$$

Fuel costs for the coal-electric-heat option are simply a multiple of the Btus required times the fuel cost per. Btu divided by the ratio of useful Btus/input Btus. In north central cities, coal costs were estimated at $\$ 0.893 / 10^{6} \mathrm{Btu}$; for other eastern cities, at $\$ 1.10 / 10^{6} \mathrm{Btu} .49$ Using heat pumps for final conversion, the useful-to-input Btu ratio from the amended net energy methodology is 0.706 .47

Detailed breakdowns of all the above calculation results, as well as overall annual costs in terms of $\$ / 10^{6} \mathrm{Btu}$, are given in Table 5.1. These figures can be compared directly to the DES options in Tables 4.6 and 1.1.

\subsubsection{Coal-to-Gas Via Gasification-to-Heat}

Coal gasification costs, unlike electrical system costs, can be based on total demand rather than on capacity. Most buildings in the cities under study currently are served by gas. Consequently, the coal gasification option is essentially a status quo option, i.e., the existing system will not be revised because high Btu coal gas merely will be substituted for natural gas. No building retrofit will be necessary. The distribution system and storage facilities already exist.

One big advantage of the gas system is its storage capability. Natural gas or coal gas $c$ an be readily stored over long periods without losing their energy content. This is not true of thermal or electrical energy. This storage capability allows a coal gasification plant to run at a high capcity factor and thus requires relatively less capital investment per unit output.

The overall net energy trajectory for the coal gas option required modification as follows: 
- A major upward escalation in gasification plant cost was necessary to reflect recent estimates. The original estimate of $\$ 371 \times 10^{6} /$ TCF increased to $\$ 1250 \times 106 /$ TCF. $* 48$

- The cost for distribution systems was deleted on the assumption that existing transmission networks may be utilized. are: 47

After correction, the capital costs for the trajectory components

$\begin{array}{llr} & \frac{\$ / 10^{9} \mathrm{Btu}}{\$ 1,200} \\ \begin{array}{l}\text { Underground } \\ \text { Rail Transport } \\ \text { Coal Gasification }\end{array} & =\frac{13,820}{680} \\ \text { Total } & =\$ 15,720\end{array}$

Estimates from Washington Gas and Light Co. project a $67 \%$ average efficiency for gas furnaces. 8 Using this factor, the overall cost of final demand is $\$ 23.463 / 10^{6} \mathrm{Btu}$. This cost, multiplied by demand figures for the various zones, gives and estimate of total capital costs.

Operation and maintenance costs are projected on the basis of the amended net energy procedure as a multiplier of capital costs. For the coal gasification: 47

O\&M Multiplier $=\frac{\text { Total Annual O\&M Cost }}{\text { Total Capital Cost }}=\frac{503}{15720}=.03200$

Fuel costs for the coal gasification option are simply dollars per Btu required times the final Btu delivered divided by the ratio of delivered/required Btus. Coal costs are the same as those used in the electric option. The useful-to-input Btu ratio was determined to be 0.353 .47

Detailed breakdowns of all the above calculations results, as well as annualized costs, were given in Table 5.2.

\subsubsection{Coal-to Oil Via Liquefaction-to-Heat}

The coal liquefaction option is treated similarly to the gasification optinn, except that additional costs for enlarged refinery storage and distribution are included.

The only major change from the original net energy procedure is that the cost of the liquefaction plant is escalated to reflect current dollar estimates. The scale-up is proportionally identical to that used for gasification plants.

*If histury repeats itself, this cost will rice in real terms as well. Thus it is probably reasonable to regard the coal gasification costs estimated here to be on the low side of real "as-built" costs realized when a coal gasification plant is huilt. 
The capital costs for the trajectory components are:47

$\begin{array}{llr} & & \$ \times 10^{-6 / 1000 ~ B t u} \\ \text { Underground Mine } & = & 980 \\ \text { Rail Transport } & = & 340 \\ \text { Liquefaction Plant } & = & 15,500 \\ \text { Refining } & = & 1,200 \\ \text { Barge System } & = & 80 \\ \text { Storage } & = & 240 \\ \text { Distribution } & = & 380 \\ \text { Total } & = & 18,720\end{array}$

Our estimates for the efficiency of an oil-fired furnace are $70.5 \%$ (advanced oil furnace assumed because replacement would be required; however, no charges have been assessed for this replacement) and this factor results in an overall final demand cost of $\$ 26.553 \times 10^{-6 / 1000}$ Btu. ${ }^{8}$ This cost, multiplied by demand figures for the various zones, gives the estimate of total capital costs.

Operation and maintenance costs are projected on the basis of the annualized net enegy procedure, as a multiplier of capital costs. For coal liquefaction, the following exists: 47

$$
\text { O\&M Multiplier }=\frac{\text { Total O\&M Costs }}{\text { Total Capital Costs }}=\frac{887}{18,720}=.04738
$$

Fuel costs are calculated by the same method used for gasification. The ratio of delivered to required Btus is 0.432 .

Detailed breakdowns of all the costs and annualized estimates were shown in Table 5.3 .

\subsection{COMPARISONS OF ESTIMATES}

A review of Table 1.1 reveals the comparisons among the various a1ternate energy supply options.

In all cases, the low-cost DES option at an $8 \%$ interest rate over 20 yrs is the least costly of the alternate technology options. It is marginally less expensive than coal conversion processes and significantly less expensive than the coal-electric option. That same low-cost option, when costed at a $20 \%$ interest rate, is esentially at parity with coal conversion options, but still very significantly less than the coal-electric option.

The high-cost DES options (at both $8 \%$ and 20\%) exceed the coal conversion option costs, but still are significantly less than the electric option.

Meaningful comparisons can be drawn only with a clear understanding of the assumptions underlying each option as outlined in the text. For example, the estimate for coal-electric assumes a low plant capacity utilization. If the excess capacity from the plant were utilized elsewhere, the costs per MBtu 
would drop. However, it would take an average load factor of about $58 \%$ to make the electric option competitive with the high-cost DES option. Even if cooling demands are served by a seasonal, intermediate load power plant, this is a very high load factor for such a plant. When considering coal conversion options, an $80 \%$ load factor is assumed because of the capabilities of storing the energy in these fuels for very long periods after production and before final use.

Another factor not fully considered is the relative technological uncertainty concerning the various options. The coal-electric option is fully proven as a heat source, and the DES system is fairly well proven. 4 The coal conversion technology must be considered "undemonstrated" on a large-scale operation. Thus, costs reflected in the coal-conversion option are only "best-guess" estimates and assume that technical problems can be overcome.

To estimate the costs of any specific cogeneration-based DES more accurately, a much more detailed study of a city should be undertaken. Such a study should emphasize, not only the technical and economic constraints, but also the indirect social and economic impacts of the alternative technologies and the institutional difficulties to be overcome if the DES technology is implemented. A general study of the indirect social and economic impacts of the technologies evaluated here is now under way at Argonne National Laboratory. Preliminary results indicate: that the DES is clearly superior to its alternatives but that a dollar value has yet to be placed on the indirect socineconomic benefits of a DES. 


\section{THIS PAGE}

WAS INTENTIONALLY

LEFT BLANK 


\section{ESTIMATES OF SCARCE-FUEL SAVINGS}

A major advantage of the DES over the existing heat supply mechanisms in the cities reported is that there is a great potential for offsetting scarce fuels usage: Table 6.1 shows the 1970 percentage of residential dwellings, by city, using different fuel types. 20

Scarce fuels supply more than $80 \%$ of the residences in each of the nine cities studies. Table 6.1 allows a direct reading of residential heat supply and Table 6.2 shows analagous estimates used for commercial and industrial buildings. These were generated by equations relating Denver and Baltimore CBD fuel used patterns 16 to their existing residential patterns 20 and applying these equations to the residential data for the eight other cities.

Given the data in Tables 4.1 and 4.2 (square footage and average demand factors), it is possible to calculate total annual Btus required according to fuel and building type by the following formula:

$$
B_{f}=\sum_{i=1}^{4}\left(F_{i} \times D_{i} \times \frac{365 \text { days }}{y r} \times P_{f i} \div E_{f}\right)
$$

where:

$$
\begin{aligned}
B_{f}= & B t u / y r \text { of given Fuel type, } f ; \\
F_{i}= & \text { square footage of building type } i \text { (Table } 4.1) ; \\
D_{i}= & \text { average heat demand per day of building type } i \text { in } \\
& \text { Btu/ft } 2 \text { (Table } 4.2) ; \\
D_{f i}= & \text { percentage of fuel type } f \text { used in building type } i \\
& (\text { Tables } 6.1 \text { and } 6.2) ; \\
E_{f}= & \text { efficiency from ground to building heat of fuel type } f .
\end{aligned}
$$

$E_{f}$ values used for estimation purposes are:

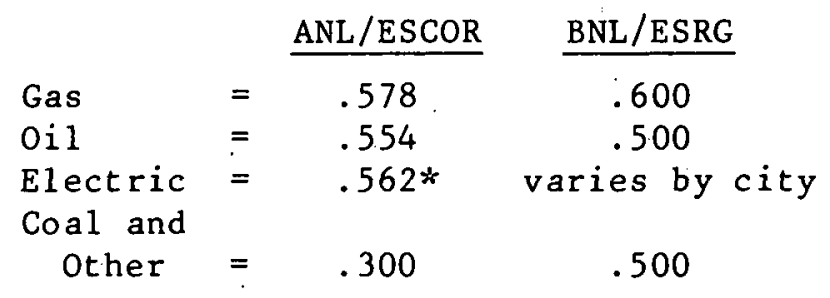

Using the above formula, the fuel use estimates presented and summarized in Table 1.2 were obtained. The scarce-fuel usage data presented in the above table are reasonable estimates of the amounts of energy used to furnish

*This efficiency is high in context of current electric heat methods because it assumes use of heat pumps. However, in view of the low saturation of electric heat listed in Table 6.1 , the error introduced is not significant. 
Table 6.1. Heating/Cooling Fuel Use Percentages for Residential Units, $1970^{18}$

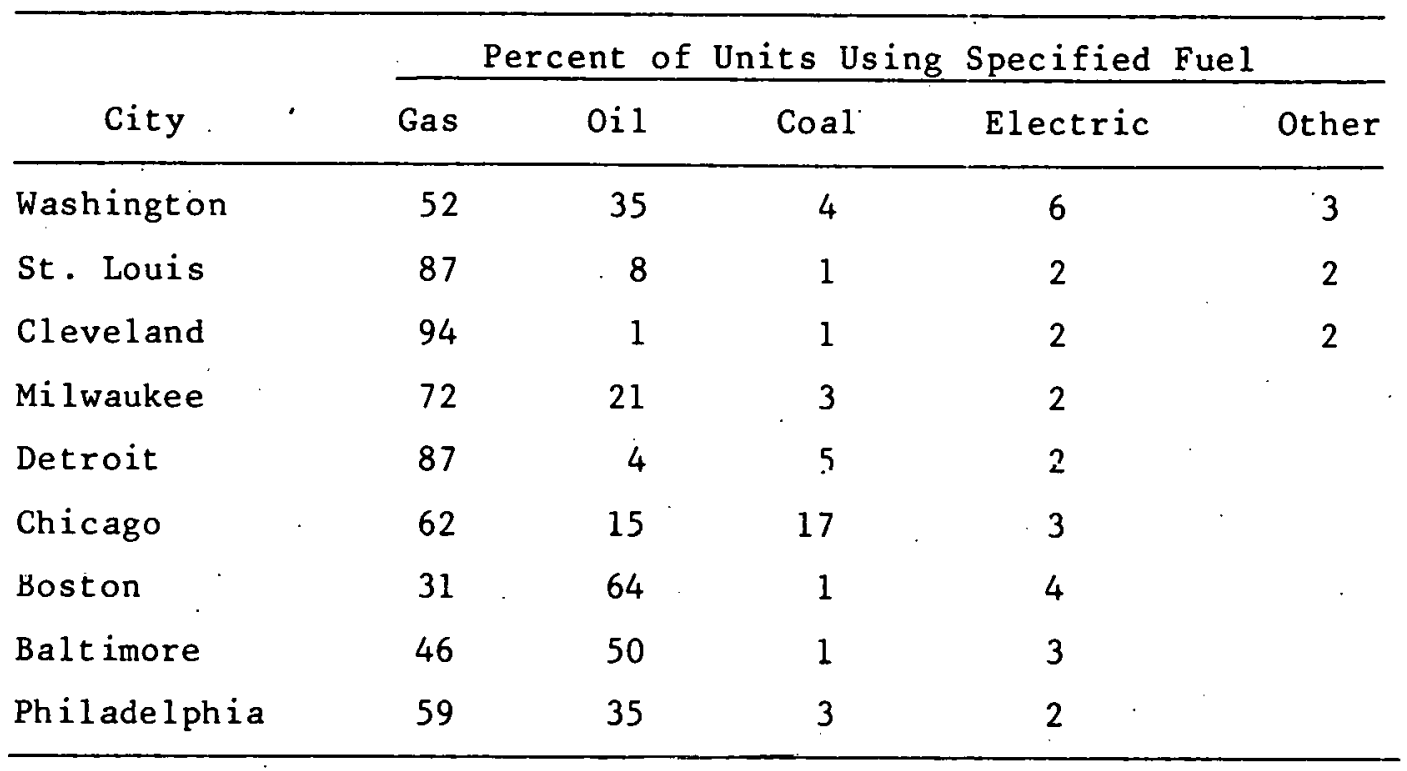

Table 6.2. Estimates of Heating/Cooling Fuel Use Percentages for Downtown Commercial/ Institutional Buildings*

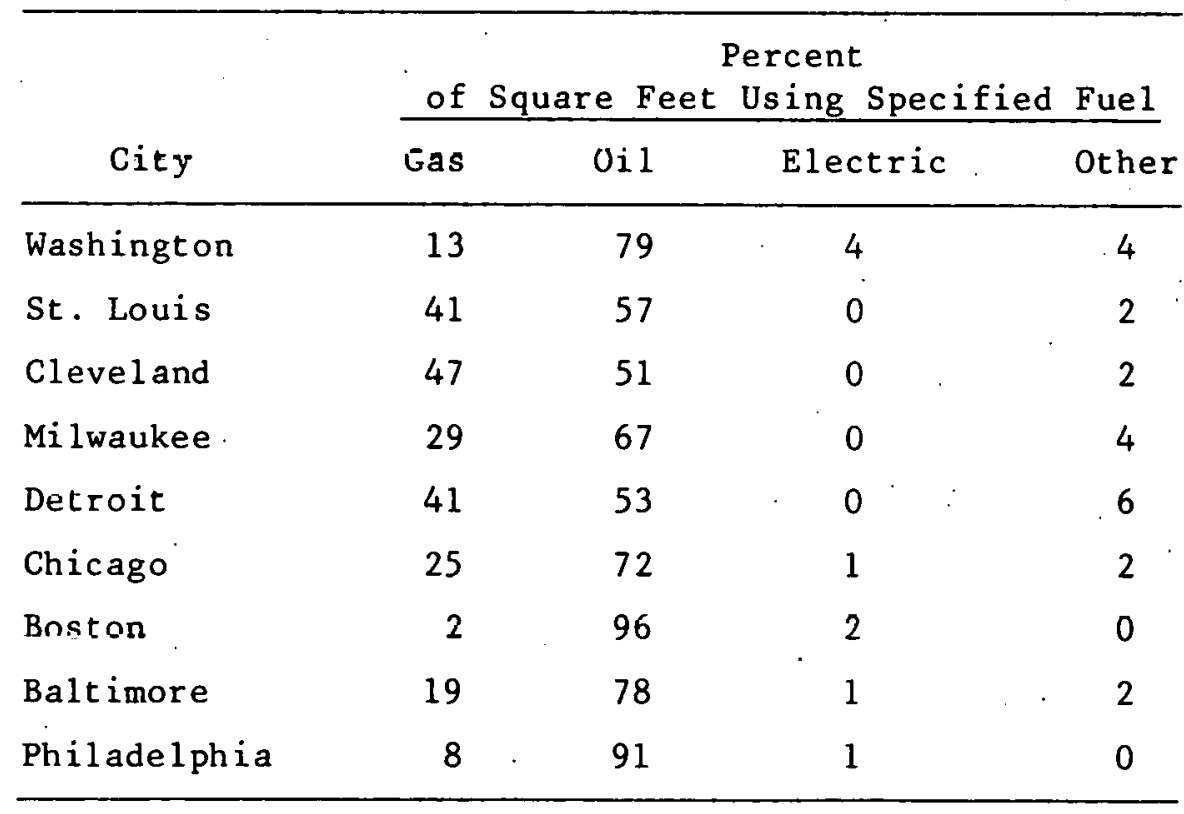

*These estimates are crude at best since they are extrapolated from the relationship between the residential sectors and the CBD's fuel use patterns for two cities only (Denver \& Baltimore) 16 
heat and hot water to the zones of the cities reported. To further assess the savings attainable by the DES retrofit, the following assumptions must be considered:

(1) The DES must provide the same energy to the end-use as did the original energy supply.

(2) The electricity produced by cogeneration is utilized as it was before retrofit took place. Because replacement capacity for electricity lost due to cogeneration is generated at a slightly lower efficiency, more fuel is required. (This added fuel. requirement is not included.) However, because all auxiliary fuel is assumed to be coal, consideration of this additional fuel would not affect scarce fuel savings; however, it would slightly raise the overall Btus utilized for total DES energy production. The difference is small because it is due only to differences in new peak generating unit efficiency vs existing unit efficiency.

(3) Fuel savings are computed on a city-wide basis.

(4) Power plants will continue to use the same fuel mix after retrofit as had previously been used. Further," retrofitted plants will be utilized in the same general operating sequence as before retrofit.

To compare the current fuel use estimates with the estimated fuel used by cogeneration under DES operation, the useful Btu requirements (Btu demand) of the city must be considered (Table 5.2 or 5.3). From the end-use energy requirements, the amount of energy which must be generated at the plant door, can be determined by utilizing the $80 \%$ in building heating system efficiency factor and $10 \%$ line-loss factor previously cited. Therefore, for each Btu required by the end-user, $1.39=1:(0.8 \times 0.9)$ Btus of energy must be generated by the plant.

The next step down the DES energy pathway involves the amount of energy input to the plant to allow generation of the required plant output. To generate this number, the heat rates of the subject plants can be utilized. Although heat rates will differ somewhat among plants (and indeed individual units) it was determined by the ANL/ESCOR study group that the generic numbers generated from previous work on Washingtion, D.C.6, would be accurate enough for this study The heat rate so determined for the thermal component is 1.95 MM Btu kWh or 0.570 fuel Btu in per thermal Btu out.

At this point, a note of explanation is necessary. The factor 0.570 Btu in/Btu out may appear, on the surface, to violate all laws of thermodynamics in that more energy is created than put into the system. This rather unique result is due to the nature of cogeneration. In essence, our work used the accounting framework that the electric component efficiency (and heat rates) were identical before and after cogeneration. With this framework and because of the generation of thermal as well as electric energy after retrofit, the overall efficiency of the system increased by approximately $100 \%$. The electric component losses are small compared to overall thermalegains. When 
these small losses are considered as Btus sacrificed to gain the large amount of thermal Btus, the accounting framework yields an efficiency credit apparently greater than $100 \%$. This somewhat unique distribution is valid for two major reasons:

(1) The increase in efficiency is totally resultant from the retrofit operations.

(2) The thermal output is the energy component which is replacing traditional scarce fuels, and is an added increment to the original electric generating system. It is this comparison of incremented gains and losses that results in high efficiencies.*

Using the abuve lugic, an overall energy efficiency factor can be found as follows:

$$
\text { Eff. }=\frac{\text { Btu } \times .80(.9)}{5702}=1.263
$$

This efficiency factor can now be used in combination with the city total end use Btus required for each city to obtain an estimate of total Btus of fuel required to run the DES. Thus, for Washington, D.C.: $25.9 \times 10^{12}$ Btu for end use $\div 1.263=20.5 \times 10^{12} \mathrm{Btu}$, which is presented in column nine of Table 1.2.

In its analysis, the ANL/ESCOR study group used the generic efficiency factor of 1.263 to determine city total cogeneration Btus. The BNL/ESCOR group, however, did its estimation on a plant-by-plant basis. Both study groups allocated the total cogeneration Btu requirements to oil, gas, coal, and nuclear according to the relative capacities and expected operating hours of the respective oil, gas, coal, or nuclear-fired retrofitted generating units.

Table 1.2 .

Results of the energy use computations for each city are. listed in

Overall Btu and scarce Btu (oil/gas) savings are now simply the result of subtracting fuel consumption after cogeneration from current fuel consumption. Results of these computations are also shown in Table 1.2. Savings of about $90 \%$ of scarce-fuel usage in the North Central Region are not at all surprising in that coal and nuclear power plants are generally substituted for oil and gas in the primary heat energy source. In the Northeast however, it is merely more efficient use of oil that accounts for the somewhat lesser scarce fuel saving percentages. In any case, it can be readily seen from Table 1.2 that cogeneration by DES gives rise to very substantial scarce fuel savings, regardless of which of the nine cities one is considering.

*The accounting method used here is analogous to marginal rates of return in economics. We might consider the cogeneration efficiency a marginal efficiency, but to some, this term could have an unintended interpretation. 


\section{REFERENCES}

1. Santini, D.S., A.A. Davis, and S.M. Marder, Economic and Technical Analysis of Retrofit to Cogenerating District Energy Systems: North Central Cities, Argonne National Laboratory Report ANL/CNSV-TM-11 (June 1979).

2. Bernow, S.S., and R.A. Rosen, An Assessment of the Potential for District Heating in Four Major Eastern Cities, Argonne National Laboratory Report ANL/ ICES-TM-11 (Aug. 1978).

3. Bernow, S.S., Energy Systems Research Group, unpub1ished information (1978).

4. Studsvik Corporation, Minneapolis-St: Paul. District Heating Study, Oak Ridge National Laboratory Report ORNL/SUB-77/13502/4 (November 1978).

5. Argonne National Laboratory, Energy and Environmental Systems Division, unpublished information (March 1977).

6. Santini, D.S., and A.A. Davis, A Test Case for the Potential Application of District Energy Systems Using Thermal Energy Cogenerated at Existing Power Plants, Argonne National Laboratory Report ANL/ICES-TM-13 (January 1978).

7. Samsa, M.E., K.A. Hub, and A.R. Evans, High-Btu Gas Supply Systems: The Characterization and Social Cost of Selected Options for Providing Gas to a Midwesterm Terminus, Argonne National Laboratory Technical Memorandum ANL/IAPE/TM-78-1 (October 1977).

8. Boyland, R.J., Seasonal Efficiency for Residential Oil-Fired Central Furnaces and Boilers, Interdepartmental Communication of the Washington Gas and Light Company (July 1977).

9. Harrison, W., et al., District Heating and Cooling Utilizing Temperature Differences of Local Waters. Preliminary Feasibility Study for the Chicago 21 South loop New Town Development, Argonne National Laboratory Report ANL/WR-77-1 (May 1977).

10. Christian, J.E., Central Cooling Absorption Chillers, Argonne National Laboratory Report ANL/CES/TE 77-8 (August 1977).

11. Salisbury, J.K., Steam Turbines and Their Cycles, John Wiley \& Sons, Inc. (1942).

12. Stodola, AK., Stoam and Gas Turbines, Vol. I and 2, Peter Smith, New York (1945).

13. Farahan, E., and J.P. Eudaly, Gas Turbines, Argonne National Laboratory Rèport No. ANL/CES/TE 78-8 (Oct. 1978). 
14. Oliker, I., Urban Area District Energy System Study, draft report 非251-06, Burns \& Roe, Inc., Orade11, N.J. (1977).

15. Jack Faucett Associates, Energy Consumption in Commercial Industries by Census Division - 1974, Consumption Studies Division, Federal Energy Administration, Washington, D.C. (March 1977).

16. Bernstein, H.M., and P.M. McCarthy, A Study of the Physical Characteristics, Energy Consumption, and Related Institutional Factors in the Commercial Sector, Hittman Associates, Inc., Report HIT-630 (1975).

17. Salter, R.G., R.L. Petruschell, and K.A. Wolf, Energy Conservation in Nonresidential Buildings, Rand Report, R-1623-NSF (October 1976).

18. Fulbright, B.E., MIUS Community Conceptual Design Study, National Aeronautics and Space Administration Report, NASA TMX-58174 (June 1976).

19. Santini, D.J., and R.M. Braid, An Econometric Model of Intraurban Location of Emitters and Receptors of Industrial Air Pollution, technical report of the NSF-RANN Environmental Pollutants and the Urban Economy project, Argonne National Laboratory (February 1977).

20. U.S. Department of Commerce, Census of Housing, 1970 Detailed Housing Characteristics, USGPO, Washington, D.C. (1972).

21. Kron, N.F., D.J. Santini, and C.F. Filewicz, A Compendium of Hourly Service and Energy Demand Profiles for Buildings, Argonne National Laboratory Report ANL/ICES-TM-18 (November 1978).

22. Dole, S.H., Energy Use and Conservation in the Residential Sector: A Regional Analysis, Rand Report R-1641-NSF (June 1975).

23. American Society of Heating, Refrigerating and Air Conditioning Engineers, Inc. (ASHRAE), Handbook of Fundamentals, ASHRAE, New York, N.Y. (1972).

24. International District Heating Association, Principles of Economical Heating, Pittsburgh, Pa. (1973).

25. Mitroiu, C., Some Concepts of Choosing Capacities and Flows of Energy for the Warm Side and Cold End, Combined Heat and Power Plants, Scientific Bulletin, University of Bucharest (1971).

26. Schel fberg, A., and A. Misu, An Analysis of the Economic Efficiency of Large Combined Heat and Power Production Systems in Romania, Scientific Bulletin, University of Bucharest (1971).

27. Colt, G., and J. Grecu, The Steam Consumption for a District Heating Power Plant, Energetica Magazine, 10(12), Bucharest (1972).

28. Grecu, I., and A. Ashendorf, The Increased Condensing Pressure Turbines for District Heating Systems, Energetica Magazine, 9(1), Bucharest (1969) 
29. General Electric Company, Steam Turbine Generators for Industrial Applications, Bulletin GEA 8511 A5, General Electric Corp., Lynn, Mass. (1971).

30. Worthington Power Recovery Turbines, Washington Large Mechanical-Drive Steam Turbines, Bulletin No. 4875-B1, Worthington Corp., Wellsville, N.Y. (1972).

31. Turbodyne SST-2 Standard Single-Stage Turbines, Turbodyne Corp. Bullet in 4805-DGA (1972).

32. Elliot AYR Single-Stage Turbines. Elliot YR Single-Stage Turbines. Elliot Single Valve Multistage Industrial Turbines. Elliot Multivalve Turbines. Bulletin H-31E, Elliot Division, Corner Corp., Jeannette, Pa.

33. Baily, I.G., R.C. Cotton, and R.C. Spencer, Predicting the Performance: of Large Steam Turbine-Generators Operating with Saturated and Low Superheat Steam Conditions, American Power Conference, Vol. XXIX, Chicago, Illinois (1967).

34. Fallah, M.H., Thermal-Electric Generation Extraction Steam Turbine Mathematical Stmucture, ACUCS Working Paper (1976).

35. Kearton, W.J., Steam Turbine Operation, Sir Isaac Pitman \& Sons, Ltd.; Lond on (1964).

36. Lopatin, B.V., Thermal Piping Systems, Technical Publishing Company, Bucharest (1967).

37. Subin, E.P., The Design of District Heating Piping Systems, Technical Publishing. Company, Bucharest (1964).

38. Johns Manville, Thermal Tables for Underground Heating and Cooling Systems, Denver (1975).

39. Iliescu, R., District Heating Piping Systems, University of Bucharest Publishing Company (1967).

40. Rose, R.W., Thermal Insulation for Buried Piping, District Heating Magazine, IDHA 62(3) (1977).

41. Aamot, H.W.C., and J.J. McFadden, Utility Distmibution Systems in Sweden, Finland, Nomway, and England, Corps of Engineers, U.S. Army, Cold Research and Engineering Laboratory, Hanover, N.H. (1976).

42. Aamot, H.W.C., and G. Phet teplace, Long Distance Heat Transmission with Steam and Hot Water, presented at International Total Energy Congress, Copenhagen (Oct. 4-8, 1976).

43. Underiground Heat Distribution System, Report No. BOR-64 for Federation Construction Council by Task Group T-54, Publication 1186 National Academy of Sciences - Natiunal Research Council, Washington, D.C. (1964). 
44. Field Investigation of Underground Heat Distribution Systems, Report No. 47 for the Federal Construction Council by Task Group T-54, Publication 1144, National Academy of Sciences - National Research Council, Washington, D.C. (1963).

45. Farahan, E., Central Heating-Package Boilers, Argonne National Laboratory Report ANL/CES/TE 77-6 (May 1977).

46. Segaser, C.L., Heat Recovery Equipment for Engine6, Argonne National Laboratory Report ANL/CES/TE 77-4 (April 1977).

47. Development Sciences, Inc., Using Net Energy Methodology for Energy Planning: Tradeoffs of Supply Vs. End Use Technologies, Volume II, Final Report, Energy Research and Development Administration Department, FE-772443/1 DS 055 UC-90j (April 1977).

48. Federal Energy Administration, National Energy Outlook, Federal Energy Administration Report, FEA-N-75/713 (February 1976).

49. Federal Power Commission, FPC News, various issues in 1975-76. 
ACKNOWLEDGMENT

The authors wish to express their appreciation to the following individuals for their combined effort in making this report available:

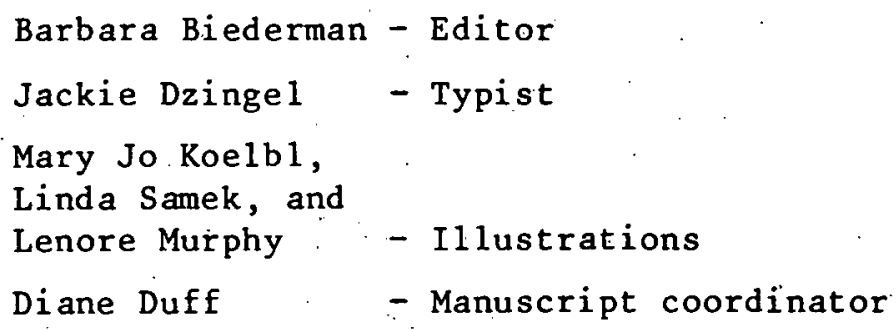

